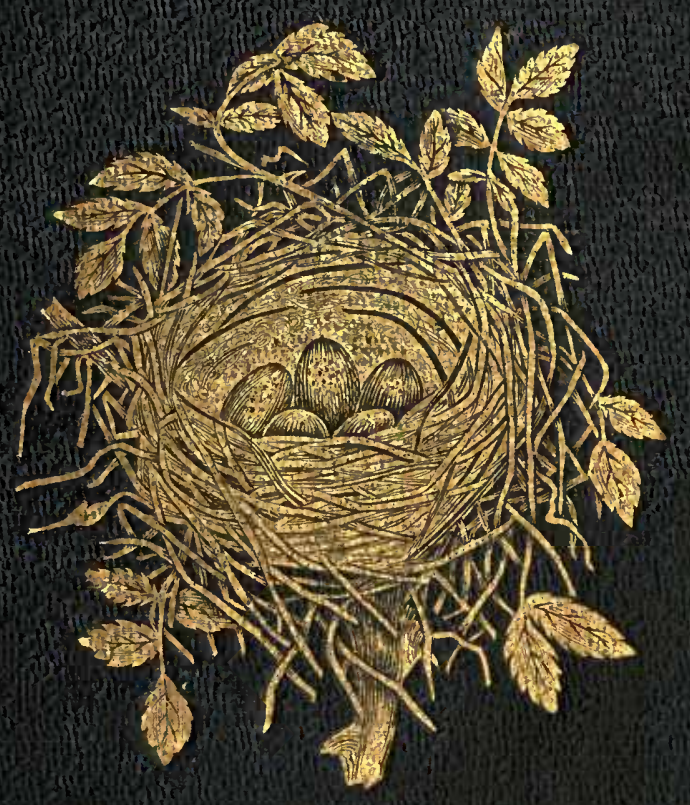




\section{3 not}

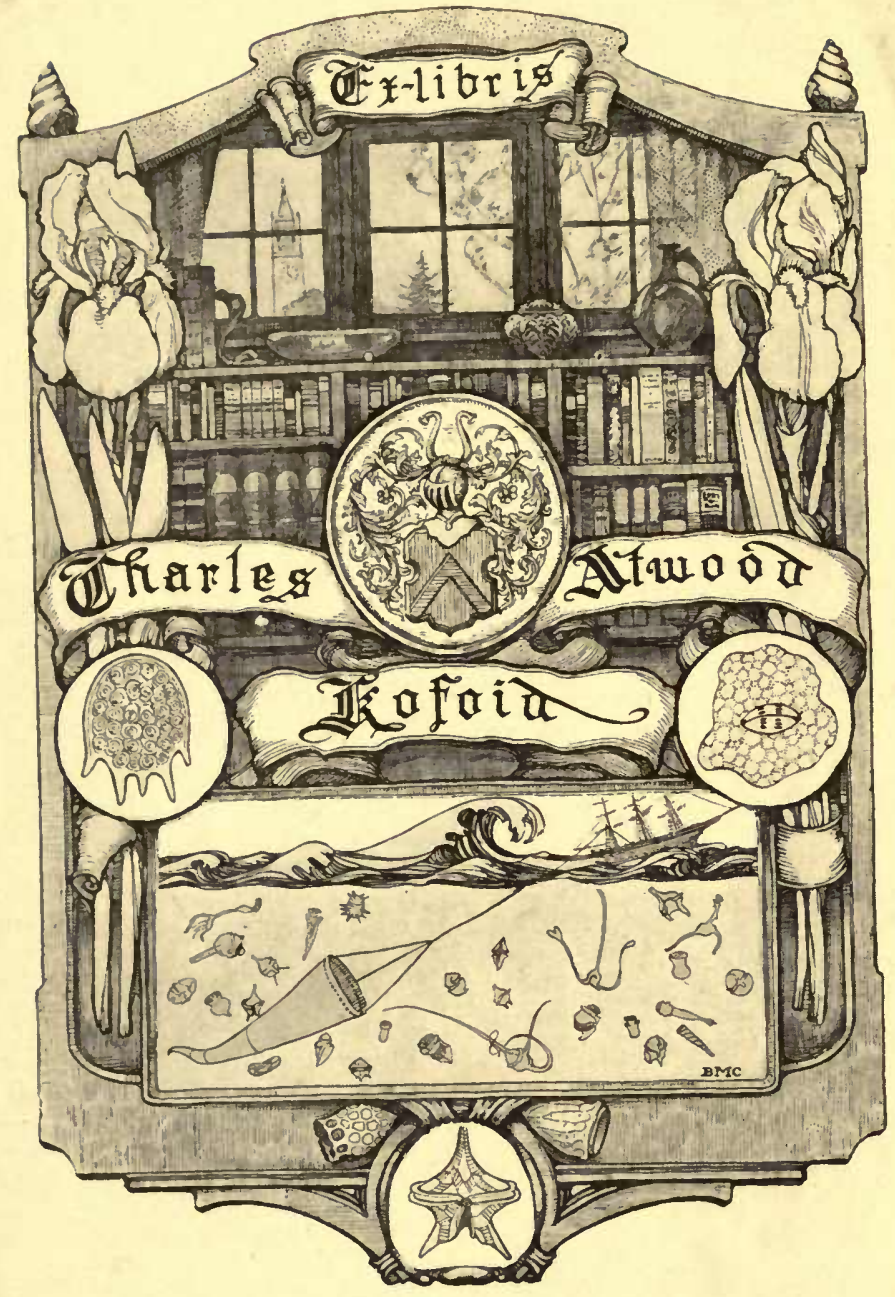




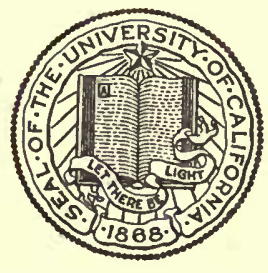

\section{THE LIBRARY $\mathrm{OF}$} THE UNIVERSITY OF CALIFORNIA

PRESENTED BY

PROF. CHARLES A. KOFOID AND MRS. PRUDENCE W. KOFOID 

$x^{2} \times x^{3}$

$\sqrt{2}+2$

$x^{2}+x^{2}=$

$\sqrt{3 x}+5$

$2 x$

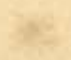

$1 \cdot 2+2=$

$4^{2}-2+2$

*

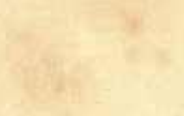

$x$

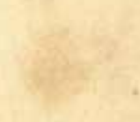<smiles>C1CC1C1CC1</smiles>

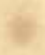

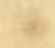

$x$

$$
x^{2}+x^{2}-4 x^{3}
$$

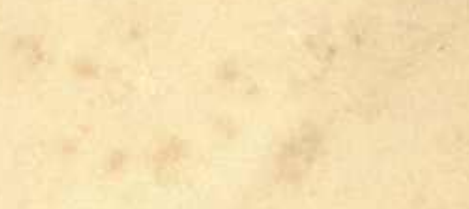

\section{"}

ixy

ㅈ․

$$
\begin{aligned}
& \text { a } \\
& 4 \\
& x^{2}=25
\end{aligned}
$$

10. 

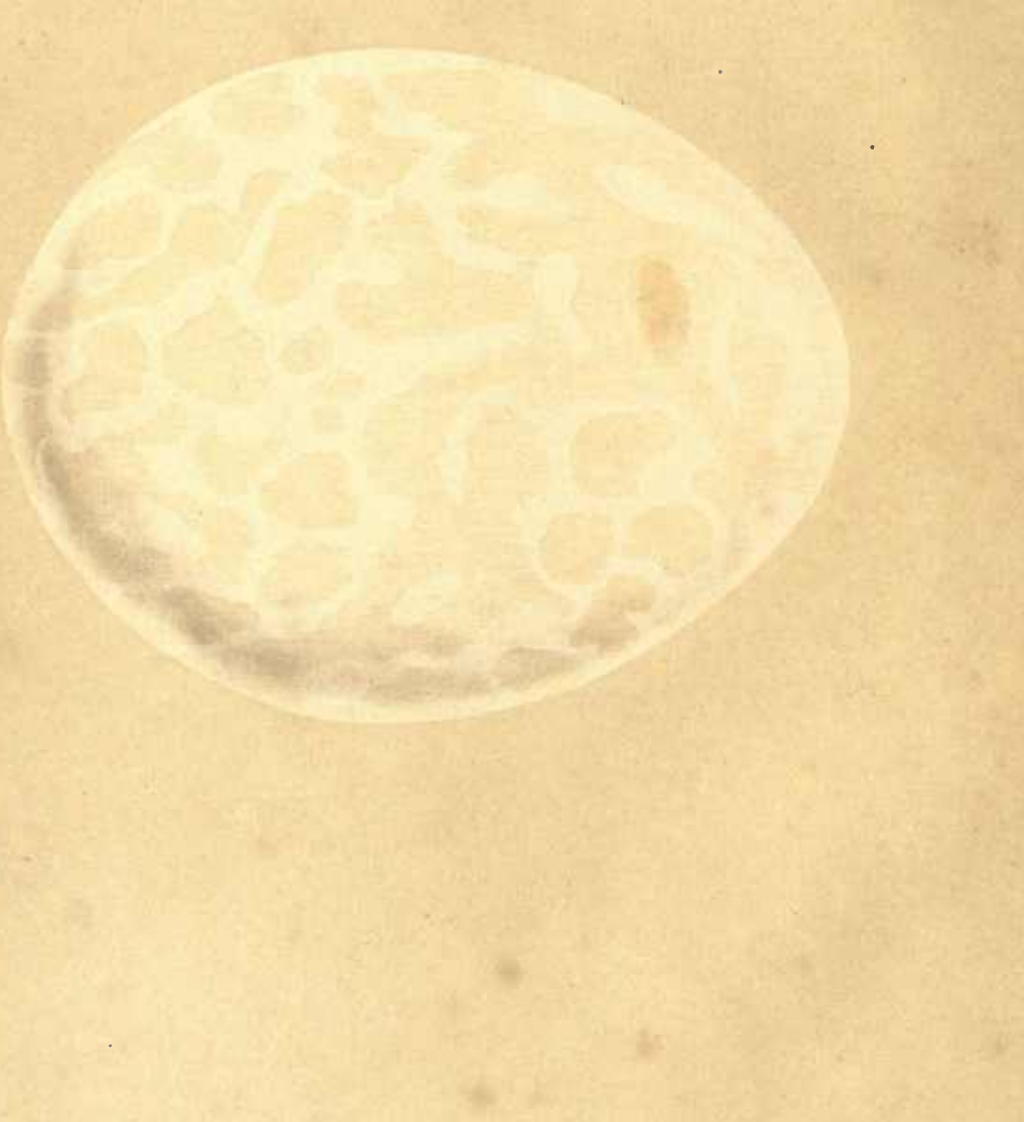


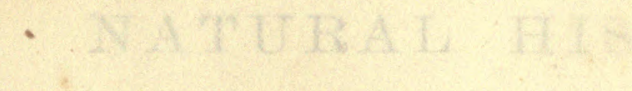

NESTS.ANT

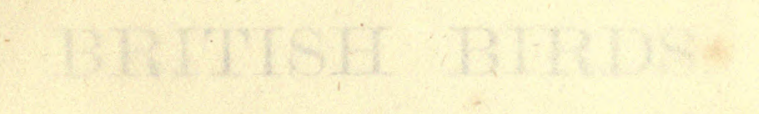

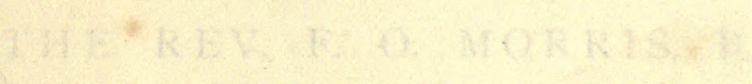

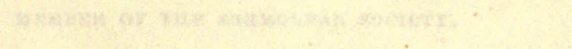

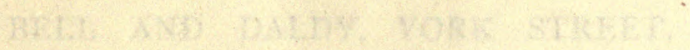

$+2$

(4)

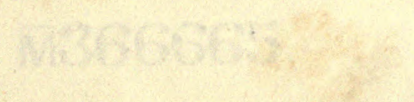



NATURAL HISTORY

OF THE

\title{
NESTS AND EGGS
}

OF

\section{BRITISH BIRDS.}

\author{
BY \\ THE * REV. F. O. MORRIS, B.A., \\ MEMBER OF THE ASHMOLEAN SOCIETY.
}

\section{SECOND EDITION.}

VOLUME I.

\section{O N D O N :}

BELL AND DALDY, YORK STREET, COVENT GARDEN. M DCCC Lxx.

1870

\section{$\bar{M} 366665$}





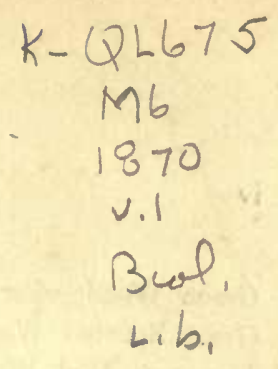

CONTENTS OF THE FIRST VOLUME.

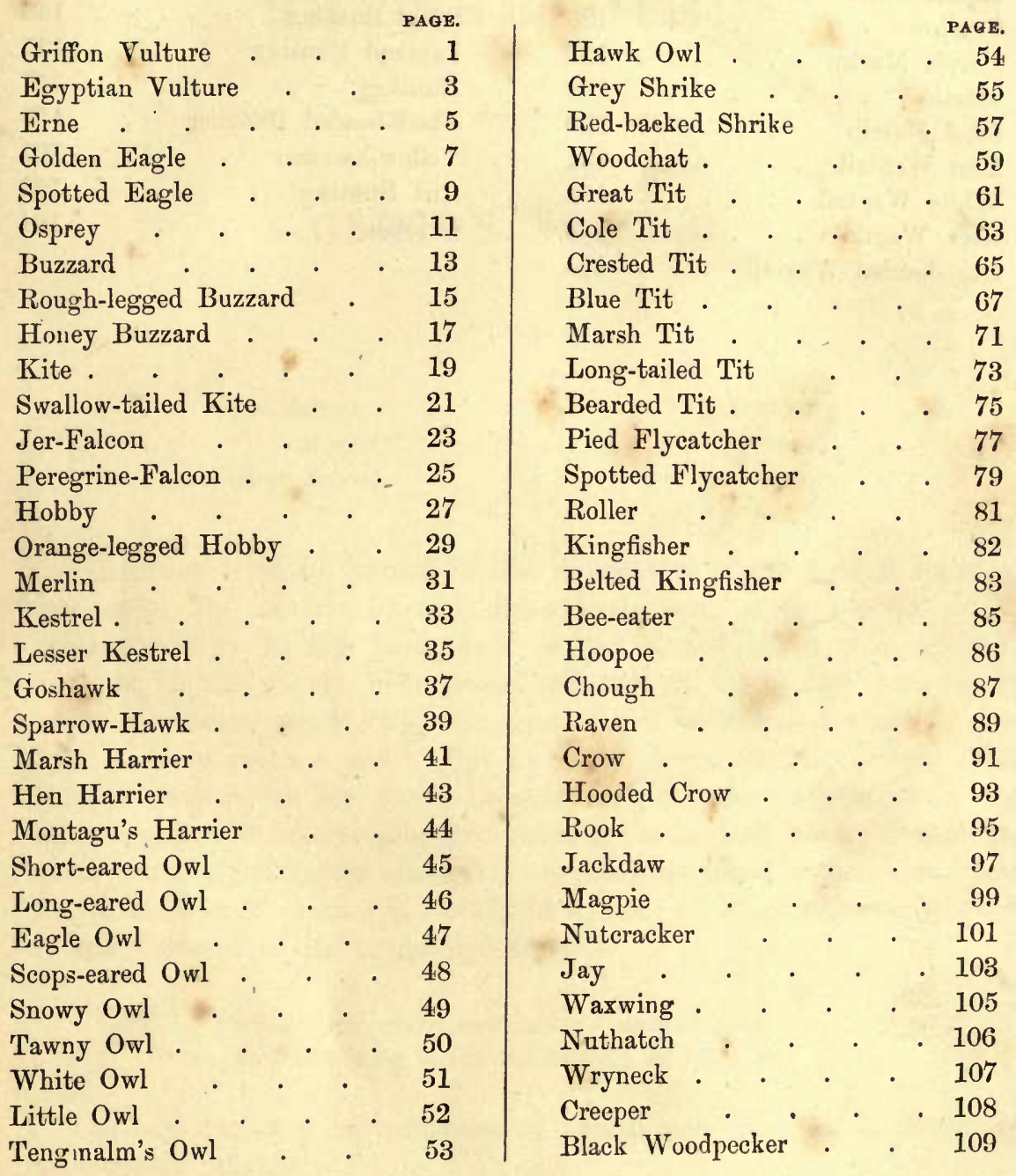




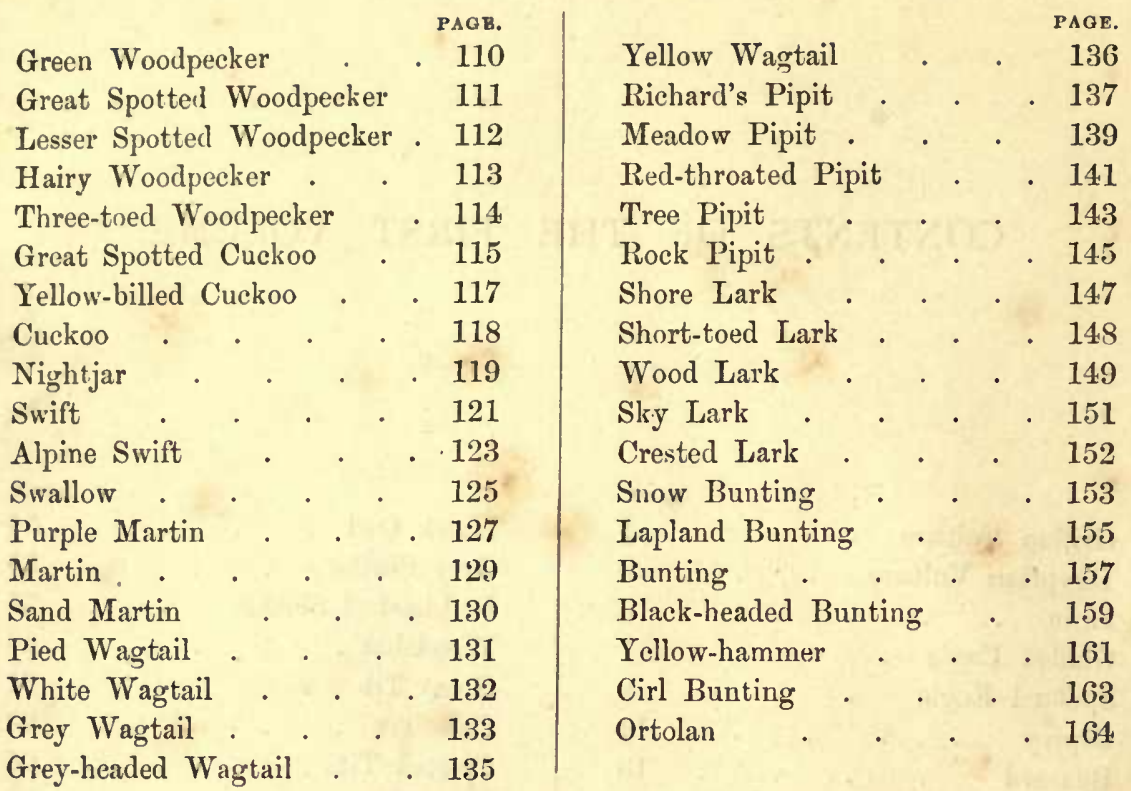




\title{
NESTS AND EGGS.
}

OF

\author{
BRITISH BIRDS.
}

\section{GRIFFON VULTURE.}

PLATE I.

Gyps fulvus,
" vulgaris,
Vultur fulvus,
Grat.

Savigni.

GOULD.

Whatever is to be known of the nidification of the Griffon Vulture, can only, by us, be learned from extraneous sources-one single specimen alone having been ever as yet met with in this country, and, as it has sagely been remarked that it takes two persons to make a quarrel, so it may with equal truth be affirmed that it takes two birds to make a nest. But to return from this digression. The Griffon Vulture, so we learn, chooses for the place of its eyrie the loftiest and most inaccessible precipices, or the highest trees. Conscious, as it were, of its being obnoxious to many acquired enemies, it takes the precaution of placing its family in a place of security, from whence it can descend to its predatory attacks-

'When from the mountain tops with hideous cry

And clattering wings the hungry Harpies fly.'

The nest can only be composed of coarse materials, and is doubtless as coarsely compacted. 
The eggs are, as is usual with birds of prey, but few in number -only two or three.

They are of a dull white colour, sometimes marked more or less with a few very pale red, or, rather, yellow blots. The form varies: in some tapering towards one end, and in others both ends being equally, or nearly equally obtuse. 
4 


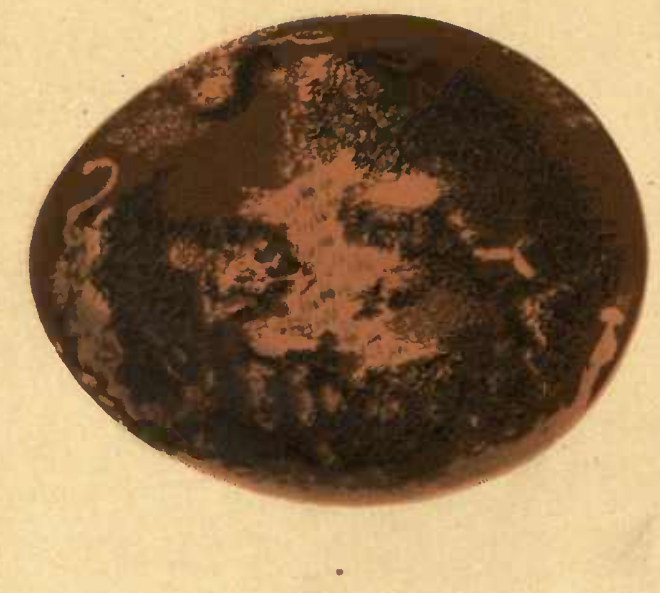




\section{EGYPTIAN VULTURE.}

PLATE II.

Neophron percnopterus,

Vultur Egyptiacus,

Cathartes percnopterus,
SAVIGNY.

LATHAM.

Temminck.

Two specimens of this species, supposed to be a pair, were observed in the county of Somerset, near the shore, or to speak more accurately, near one of the shores of the Bristol Channel, in the month of October, in the year 1825. Whether, indeed, they were a real or only an apparent pair-'par impar'-can certainly now never be decided, for one only of the two was obtained; the other, though it remained a few days in the neighbourhood, which certainly favours the supposition that they may have been husband and wife, then took its departure; perhaps in quest of a fresh mate; has never been seen from that day to this; and, as certainly, never will be seen, at all events to be recognised, again. The question must therefore ever remain unsettled, and, as already observed, this having been the only pair, or pseudo pair, that have ever made their way to these islands, we cannot predicate much, of our own immediate knowledge, of the nest and eggs of the Egyptian Vulture.

But though 'hearsay is no evidence' in a court of law, yet it will, because from the nature of the case it must, always be allowed to have its due weight 'in foro-scientix;' and the following is the recorded deposition that I am able to tender on the subject:-

The nest is placed among high and inaccessible precipices, in crevices and clefts of mountains; whence the birds-

'From dark recesses where they lie, Or from another quarter of the sky, With filthy claws thcir odious meal repeat.' 
It is built about the end of March, and the young are not hatched until late in May, where they remain until July, not being able to take flight before that time. Here again we see the wise ordering of Providence, in a different arrangement from that which prevails with regard to so many useful or harmless birds, where two or three, or even more broods are hatched in the year.

The eggs are mottled or spotted more or less with brown or reddish brown, and frequently as much so as those of the Kestrel; one or the other end being occasionally more deeply tinted than the rest; they are widest in the middle, and taper towards each end. Sometimes they are of a white colour, or bluish white. 



\section{ERNE.}

PLATE III.

$\begin{array}{ll}\text { Haliaëtus albicilla, } & \text { Serır. } \\ \text { Falco albicilla, } & \text { Montagu. Gmelin. } \\ \text { Aquila albicilla, } & \text { Jenyns. }\end{array}$

THE nest of the Erne is a large structure, or rather, in fact, at least frequently so, after its fabrication in the first instance, a superstructure, the original one being built upon from year to year. It is as much as five feet wide, and very flat, having only a slight hollow in the middle, and is a mass of sticks, heather, or sea-weed, as the case may be. These rough materials are arranged in as rough a manner, being slovenly put together, and lined with any such soft materials as the architects may be able to procure. It is placed on some rocky precipice, or in the hollow of a crag or rock overhanging the sea, or else in some inland natural fortress, such as an island in the centre of a mountain lake, or sometimes on a rock at the edge of one, whence the Erne-

\section{'from her care on high \\ Casts on the rout her wondering eye.'}

The male bird takes his turn at incubation with the female. The Erne is said to be less strongly attached to its haunts than the Golden Eagle, but it seems to be in some degree fond of them, and not unfrequently returns to the same breeding-places for several years in succession; probably indeed nothing but some 'pressure from without' would prevent its always doing so for the period of its own natural life, and then transmitting it as an heirloom to its descendants.

As is the case with the rest of the tribe to which it belongs, the eggs of the Sea Eagle are, by a merciful provision, few in 

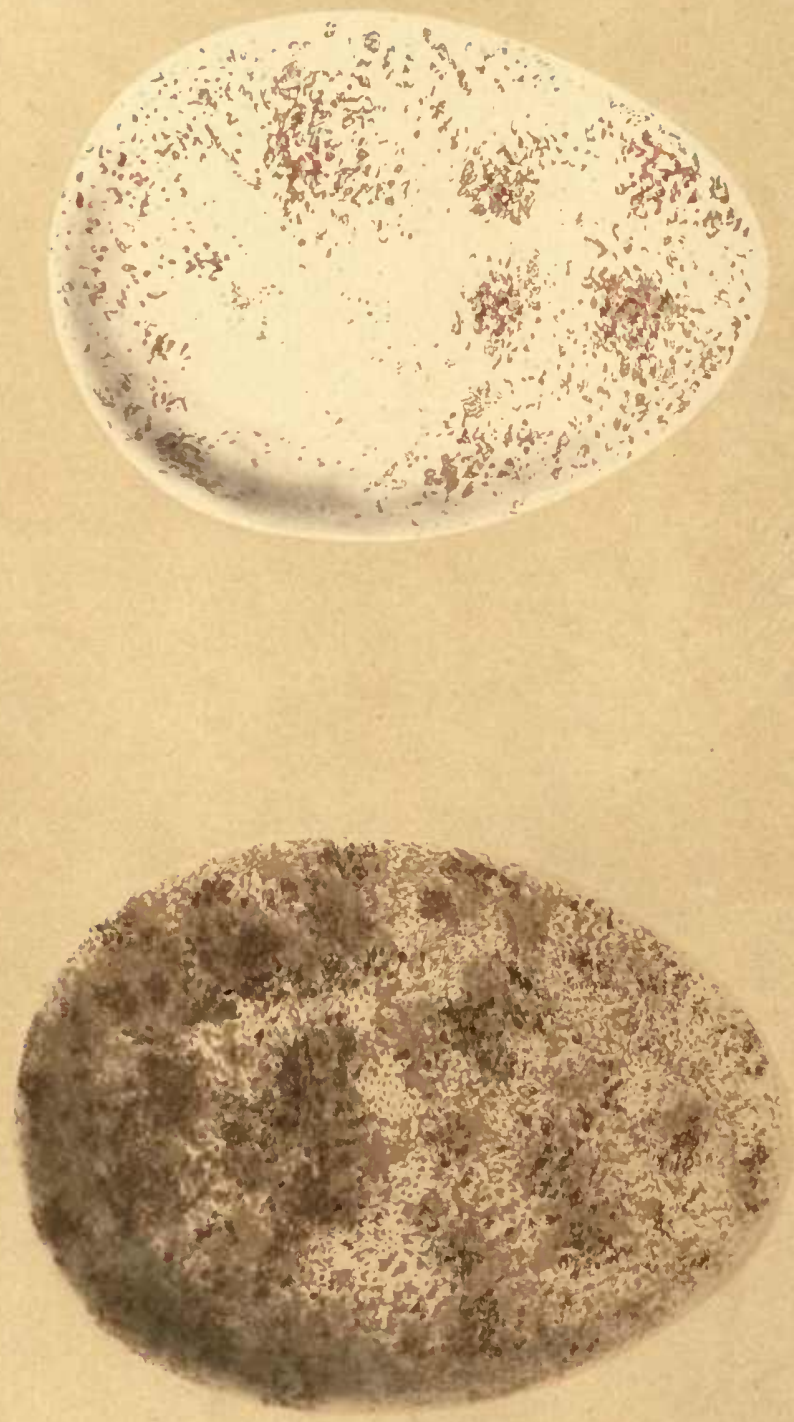


\section{GOLDEN EAGLE.}

PLATE IV.

\author{
Aquila chrysaëtos, \\ Falco chrysac̈tos, \\ "fulvus,
}

SeIBY.

Montagu.

LINNæUS.

LIKE the preceding species, the Golden Eagle locates its nest among high and inaccessible rocks and precipices, or on the rifted bole of some hoary tree, which formerly grew up in vigour in the lonely solitude, but now only remains a mournful wreck, 'lean, rent, and beggared by the strumpet wind.' Occasionally, though less frequently, a forest tree is pitched upon, reference being naturally had, as was the case with other predatory freebooters in the olden days, to a good look-out, both for purposes of aggression and self-defence. The Eagle's plume was no unfit badge for many an ancient chieftain, and the cap too of many a truly noble man has worn it.

'Fitzjames alone wore cap and plume,

And Snuwdown's knight is Scotland's king.'

The nest is very large, and the more so, inasmuch as it is always, where possible, re-constructed of, or rather built upon, the old materials, the same eyrie being mado use of for many successive years, or it may even be for many generations; the consequence of the most favourable locality as to food and security combined having been originally selected. The same instinct that prompted the Eagle of a thousand years ago, guides with the like unerring judgment his descendant of our own day in the nineteenth century.

The nest, according to some, has no lining, but is stated by others to be lined a little with grass or wool; and where these cannot be 
procured, or not in sufficient abundance, with small sticks, twigs, rushes, sea-weed, heather, or any kindred materials.

The eggs, which are generally only two in number, but in some instances three, are white, sometimes greyish white, and sometimes completely mottled or marbled over with light russet brown. 



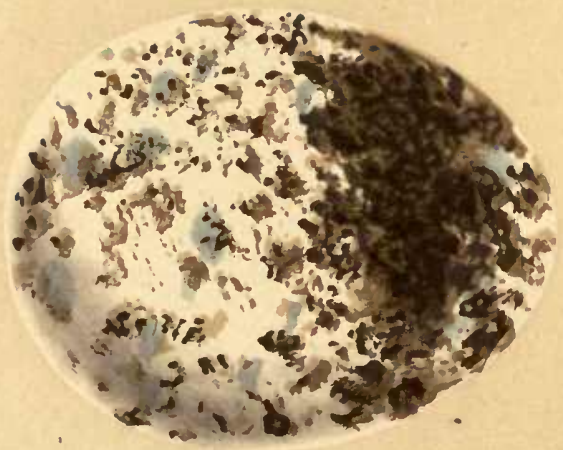




\section{SPOTTED EAGLE.}

PLATE V.

\author{
Aquila navia, \\ " melanaetos, \\ Falco navius, \\ " maculatus, \\ Morphnus congener,
}

GouLd.

SAVIGNY.

Temminck.

Temarinck.

ALDROVANDUS.

The Spotted Eagle is described as building its nest in high trees, but probably other situations, such as those which its congeners resort to, are by it also, in like manner, made use of.

It appears, too, as will be shewn to be the case with the Osprey, to permit small birds to build without molestation, let, or hindrance, in the immediate vicinity of its nest, or even in the outer parts of the nest itself. In reference to a similar case of this kind, one of my correspondents has suggested that the motive may be to suffer them to grow up there as a sort of living larder for the supply of the future wants of the landlord. I do not, however, suppose that the Spotted Eagle can with justice bo suspected of any such 'ad captan. dum' intention.

The eggs are generally two in number. They vary considerably in colour and markings, are generally of an oval shape, and sometimes, though but very rarely, taper towards the smaller end.

One variety is white.

A second, white, thickly spotted at the larger end.

A third, white, one half towards the smaller end thickly spotted with large spots.

A fourth, white on half the surface; the other half so thickly spotted with red spots, as to be almost totally of that colour.

roL. I. 
A fifth, white, slightly spotted at the larger end with pale red spots, with a zone or belt of thickly marked spots round the smaller end.

The original drawing was taken from an egg then in the collection of Dr. Pitman. 


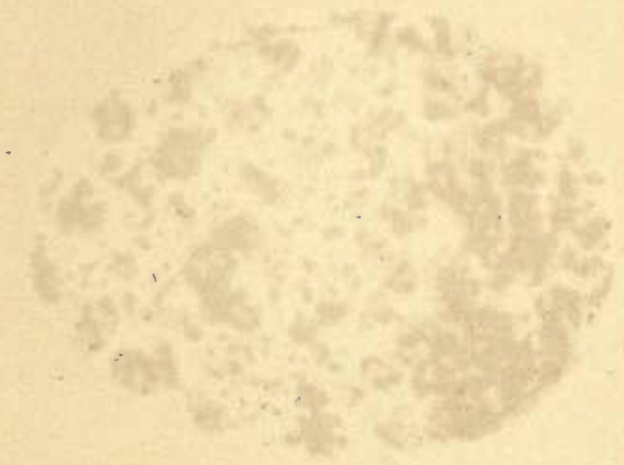




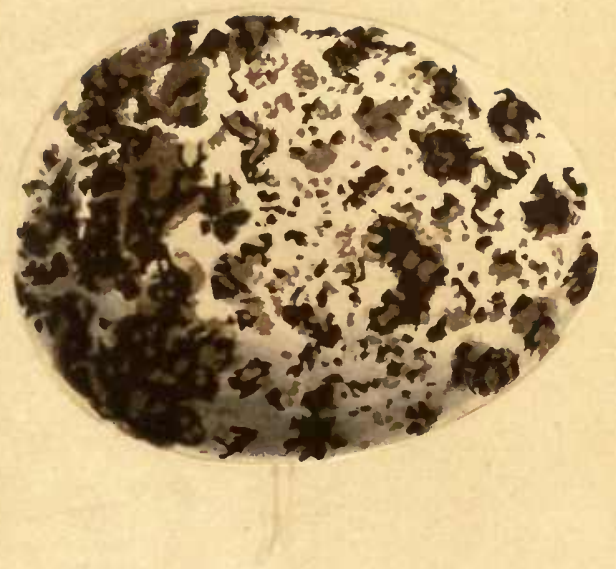




\section{OSPREY.}

FISHING HAWK.

PLATE VI.

Pandion haliaëtus,
Falco haliaëtus,
Balbusardus haliaëtus,
Aquila haliaëtus,
SAVIGNY.

Bewıк.

Flemisg.

JENYNS.

If the lone tower whose time-worn remains still abut on the edge of the solitary islet of the mountain lake, or hang over the gorge of some precipitous ravine, could now 'a tale unfold,' many is the startling legend it would tell-many a deed of blood; of bravery or of treachery; of honour or of shame. Now the Osprey is its sole tenant. The eagle eye of the Highland chieftain long since saw at a glance where the soul that looked through could best suit its plans, and thither a kindred purpose guides the bird of prey. Any forsaken building, too, if remote from human visitation, answers its motive as well, and is accordingly resorted to.

But not only has many an ancient fortress mouldered into dust since the tenancy of the Osprey's lease, which dated perhaps from the time that it was first left to go to ruin, was thus run out, and has left the bird to seek a home elsewhere,-

'And down the lone vale sail away

To more profound repose,'

but before its foundations were laid, the same want had to be supplied, and the primeval rocks then gave the bird its secure shelter, even as they still continue to do. Here, then, also the Osprey's nest is built, upon the summit of an island crag, or on some strong natural fastness by the border of the ocean, the river, or the lake.

Trees are also built on; and where these birds are unmolested or 
encouraged, as in some places they are, a colony is formed in the fishing season, sometimes amounting to two or three hundred pairs. The nest is placed at a height of from seven or eight to fifteen, and from that to fifty feet from the ground. If on a ruin, the highest point of the building is selected, generally the chimney-a necessary appendage even to a border castle. It is a cumbrous structure-an immense pile of large sticks and branches, some of them as much as an inch and a half in diameter; the whole forming a mass easily discernible at the distance of half a mile, or more, and in quantity enough to fill a cart. How it is that it is not blown down, or blown to pieces by a gale of wind, is a difficulty which is not very easy to give a satisfactory solution of. It occasionally is heaped up to a height of four or five feet, and is from two to three feet in breadth, interlaced and compacted with sea-weed, stalks of corn, grass, or turf; the whole, in consequence of annual repairs and additions, which even in human dwellings so often make a house larger than it was originally intended to be, not to say unsightly, becoming by degrees of the character described above.

The Osprey breeds at very different times of the year in different latitudes - in January, February, March, and April, and the beginning of May; the last-named appears, in this country, to be the period of its nidification. The saline materials of which the nest is composed, and perhaps also the oil from the fish brought to it, have the effect in a few years, of destroying the tree on which it has been placed. The male partially assists the female in the business of incubation, and at other times keeps near her, and provides her with food; she sits accordingly very close.

It is a curious fact that smaller birds frequently build their nests in the outskirts of those of the Osprey, without molestation on the one hand, or fear on the other. Larger birds also build theirs in the immediate vicinity, without any disturbance on the part of either.

The eggs differ considerably in size and shape, some preserving the rotundity of form which is characteristic of the whole family of rapacious birds, while others tend more towards a point at one end, the latter indeed being more peculiarly a distinction of the present species. They are commonly only two in number, but occasionally three, and in some instances, though but very rarely, as many as four.

Their ground colour is white, or dull yellowish, or dull brownish white, much mottled over, particularly at the thicker end, and in an irregular manner, with brown or rust-colour, with some specks of light brownish grey.

The larger spots are sometimes of a very fine rich brown. 


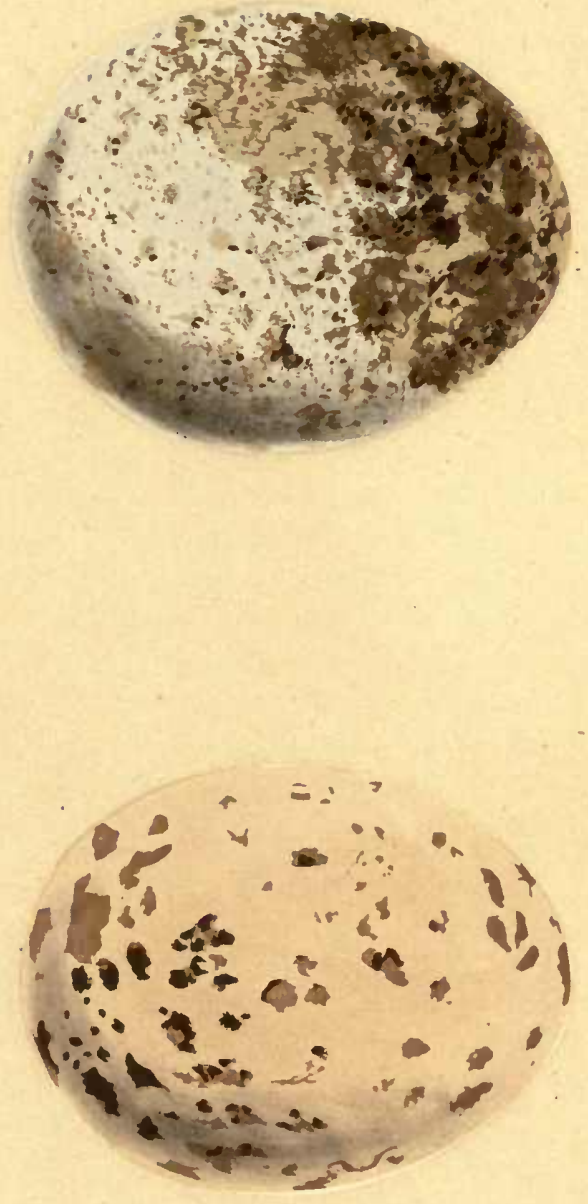


\section{Th107\%}

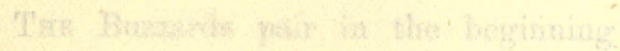

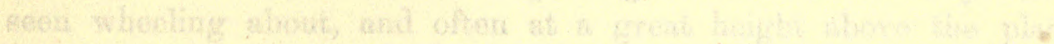

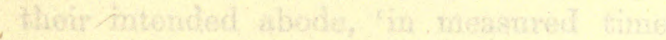

The nesti, which is butis of larie

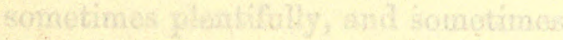

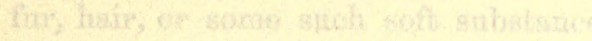
woods, and also in the clotes and f

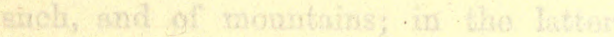

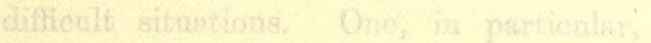

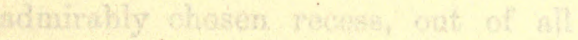

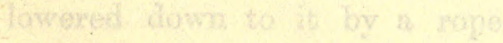

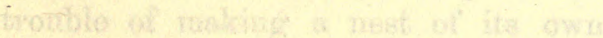

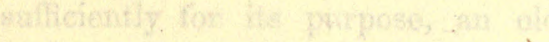

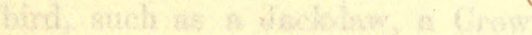

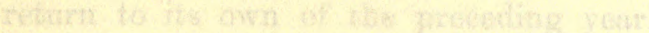

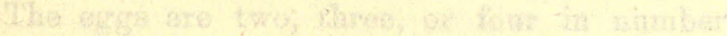

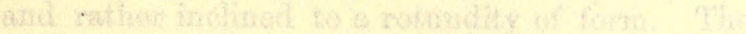

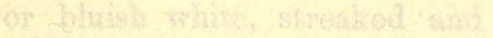

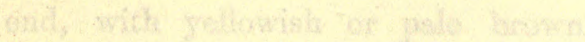
(rikiter

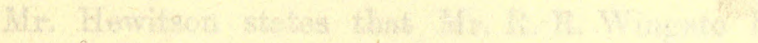

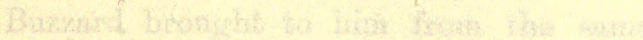

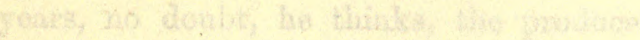

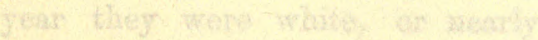

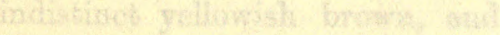

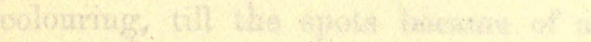





\section{BUZZARD.}

PLATE VII.

Buteo vulgaris, Falco buteo,
Fleming.

Pennant.

The Buzzards pair in the beginning of March, and may then be seen wheeling about, and often at a great height above the place of their intended abode, 'in measured time,' in slow and graceful flight.

The nest, which is built of large and small sticks, and is lined, sometimes plentifully, and sometimes sparingly, with wool, moss, heather, fur, hair, or some such soft substance, is placed both on trees in large woods, and also in the clefts and fissures of cliffs, and on ledges of such, and of mountains; in the latter case, in the most secure and difficult situations. One, in particular, I well remember in a most admirably chosen recess, out of all possible reach, except by being lowered down to it by a rope. Not unfrequently, to save itself the trouble of making a nest of its own, it will appropriate, and repair sufficiently for its purpose, an old and forsaken one of some other bird, such as a Jackdaw, a Crow, or a Raven, and will also frequently return to its own of the preceding year.

The eggs are two, three, or four in number, generally the former, and rather inclined to a rotundity of form. They are of a dull greenish or bluish white, streaked and dotted, more especially at the thicker end, with yellowish or pale brown. Sometimes they are perfectly white.

Mr. Hewitson states that Mr. R. R. Wingate had the eggs of the Buzzard brought to him from the same place for several successive years, no doubt, he thinks, the produce of the same bird. The first year they were white, or nearly so; the second year marked with indistinct yellowish brown, and increasing each year in intensity of colouring, till the spots became of a rich dark brown. 
. 

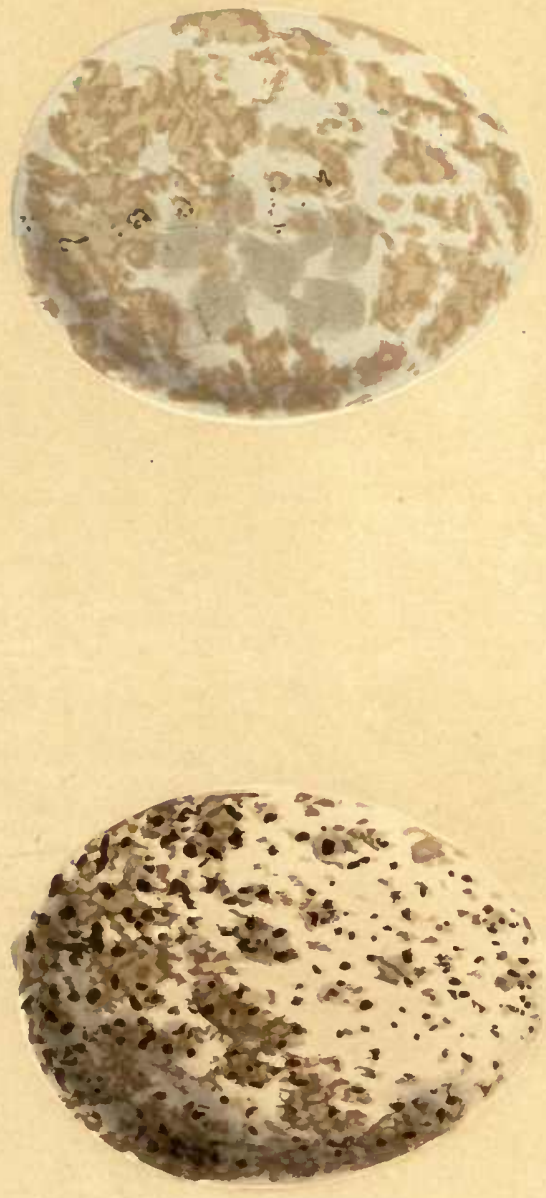


\title{
ROUGH-LEGGED BUZZARD.
}

\author{
PLATE VIII.
}

Buteo lagopus,
Falco lagopus,

Freming.

Pennant.

LIKE the preceding species and other rapacious birds, the Ronghlegged Buzzard seeks the protection of lofty trees or precipitous rocks for the place of its eyrie.

The nest is composed of sticks, and is slightly lined with soft materials, and, as is the case with many other kindred birds, the original nest is repaired to, and repaired from year to year; a predilection seeming to be entertained for the same building-place, for obvious reasons.

The eggs, from three to five in number, vary much in colour, some being nearly white; others more or less darkened with blots of a grey hue.

I cannot anywhere better give than here, 'in limine,' the opinion of H. F. Walter, Esq., which he has favoured me with on this subject, namely that the eggs of all rapacions birds of the Hawk tribe have colour, and only lose their colour when the bird has laid several eggs, the last egg being often white, or nearly so; and that young birds generally lay more colourless eggs than old birds.

I may here also mention that there seems reason to think that many colourings of various eggs are adventitious, and not intrinsic. Certain it is that they are sometimes easily washed off. 


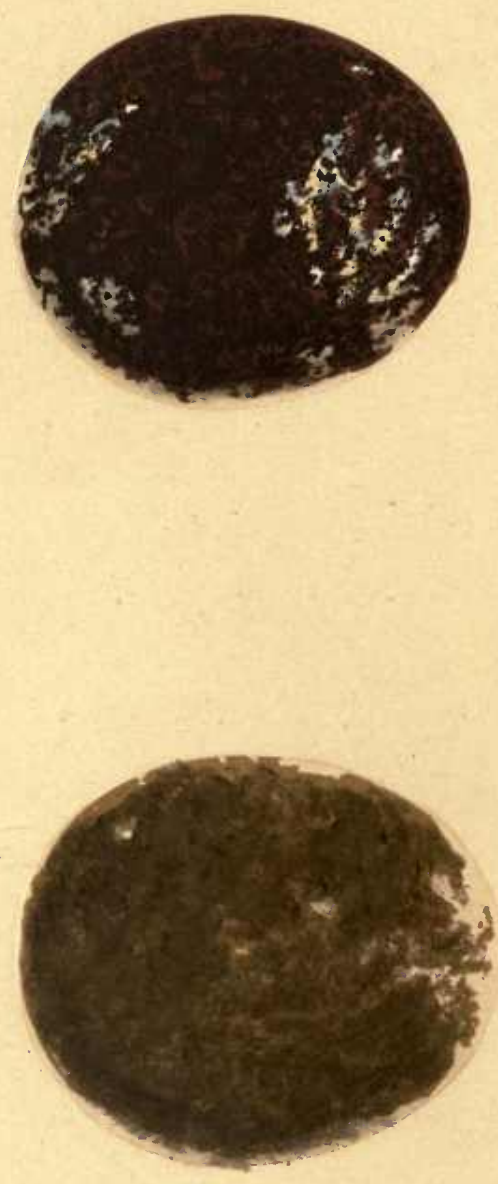


\section{HONEY BUZZARD.}

PLATE IX.

Falco apivorus,

Pennant.

The Honey Buzzard begins its nest in May, and the young are hatched, according to White of Selborne, at the end of June, so that the period of nidification must be in the month of May, or the early part of June.

The same well-known and always popular author describes the nest of this species as being built in trees, in the angle formed by the lower branches, and flat in shape. It is composed of sticks, larger and smaller, and is lined with leaves or wool, or probably any soft materials that the birds can procure. It sometimes appropriates to itself the old nest of a Kite or other bird. 'Fools,' says the proverb, 'build houses for wise men to live in;' and the remark, it would appear, may sometimes apply to birds.

The eggs are two or three in number, and of a general dull rusty red colour, much blotted with still deeper shades of the same, somewhat like those of the Kestrel in general appearance. They are of a rich appearance, but vary from each other in some degree.

One variety is of a dark reddish brown, mottled, marbled, and blotted over with darker marks of the same.

A second is of a fine very light orange rusty red general colour, mottled, spotted, and slightly waved all over with a darker shade of reddish brown.

A third is somewhat of an olive brown general hue, with many spots and markings of a rather darker colour, and a few large irregular waved lines, here and there widened out into a blot of a still darker shade of the same.

A fourth is of a general yellowish rusty red colour, handsomely blotted over with darker and lighter markings of reddish brown.

voL. I. 
A fifth is a curious mixture of reddish spots and markings at the thicker end, with white shewing through here and there, and of a dull greyish brown at the smaller end, streaked with rows of small spots run together, and also dotted with single ones, some of them brown, and some of an orange tint.

A sixth is of a general greenish brown hue, a faint reddish cream-colour shewing through, with large marbled marks of the former, the thicker end being almost entirely covered with them.

A seventh is of a faint reddish cream-colour, which is entirely hidden at the thicker end with very dark reddish brown, and considerably also towards the smaller end with large patches of the same, and a few smaller and rather lighter ones. 

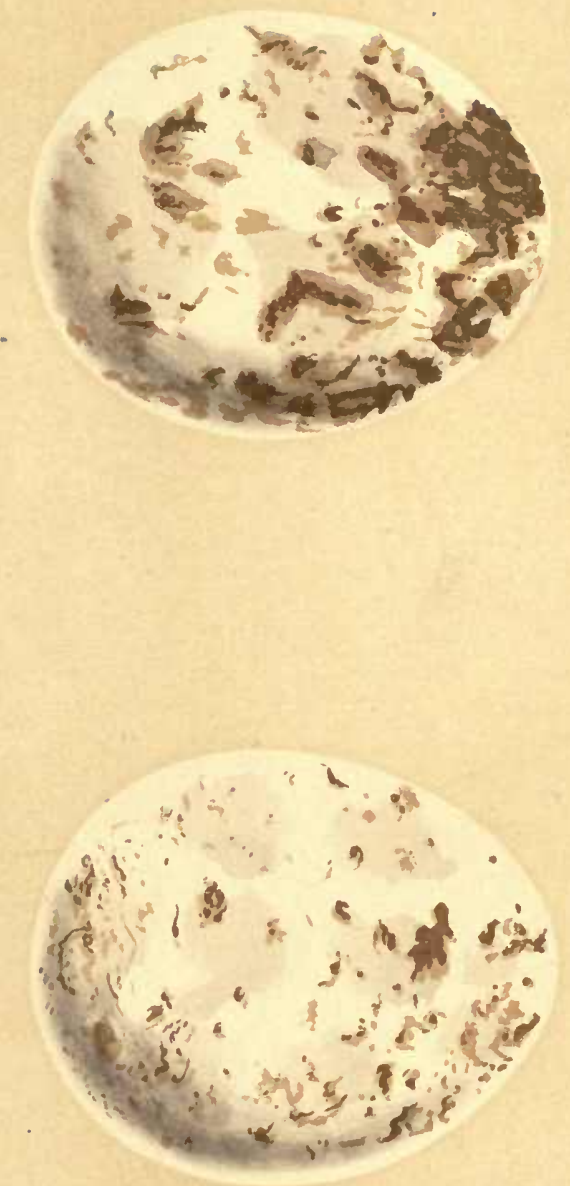


\section{KITE.}

GLEAD. PUTTOCK. FORK-TAILED KITE.

PLATE X.

\begin{tabular}{|c|c|}
\hline $\begin{array}{l}\text { Milvus regalis, } \\
\text { " ictinus, } \\
\text { " vulgaris, } \\
\text { Falco milvus, }\end{array}$ & $\begin{array}{l}\text { Brisson. } \\
\text { Linnzeus. } \\
\text { Flemina. } \\
\text { Linnzeus. }\end{array}$ \\
\hline
\end{tabular}

The nest of the Kite is built 'yearly in the spring,' for the most part in the covert of a thick wood, and is placed between the branches of some tall tree, but rather in the middle than towards the top. Occasionally also it is located on some rocky precipice. It is composed of sticks, and is lined with any soft material, such as straw, hair, grass, wool, or feathers. In shape, if the word may be applied to that which is almost shapeless, though rather more closely compacted than that of some other birds of the Hawk family, it is rather flat.

The eggs, which are two or three in number, rarely four, rather large, and somewhat more than ordinarily round, very much resemble, in some instances, those of the Common Buzzard: and possibly this fact may afford some confirmatory justification of the juxtaposition of these birds. The ground colour is a dingy white, bluish, or greenish white, or dull brownish yellow.

One variety is minutely dotted over with yellow or brown.

A second is waved with linear brown marks.

A third is blotted here and there with brown, or reddish brown, especially at the lower end.

A fourth has a few yellowish grey spots and blots all over, especially at the smaller end, and least in the middle.

A fifth is still more deeply marked with the same colour, and in a 
KITE.

similar way, but most so on the middle and towards the thicker end. A sixth is very pale yellowish brown, with a number of small dots and blots, and a few small streaks of a darker shade of the same.

A seventh is bluish white, with a few small irregular yellowish brown patches, principally at the smaller end.

An eighth is a dull white ground, very deeply blotted with dark rich yellowish brown at the thicker end.

A ninth, white, much marbled over, chiefly at the ends, with dull light orange brown.

A tenth is white. 


$$
6
$$




\section{SWALLOW-TAILED KITE.}

PLATE XI.

\author{
Elanus furcatus, \\ Mitvus furcalus, \\ Nauclerus furcatus, \\ Falco furcatus,
}

\author{
FLEMING. \\ JENYNS. \\ GoULD. \\ WILSON.
}

THE pairing time of this exceedingly elegant species is in the beginning of April, and the male and female sit alternately; each in turn feeding the other. They have, as other rapacious birds, only one brood in the year.

The nest, which, as a matter of course, is composed of sticks, and is lined with grass and feathers, and probably any such materials as may be met with at the time when they are required, is usually built on the top of a tall tree; and the vicinity of water is preferred, probably on account of the insects to be found there, which form the principal part of the food of this bird.

The eggs, which are from four to six in number, are described as being of a greenish white colour, irregularly blotted with dark brown at the larger end. 

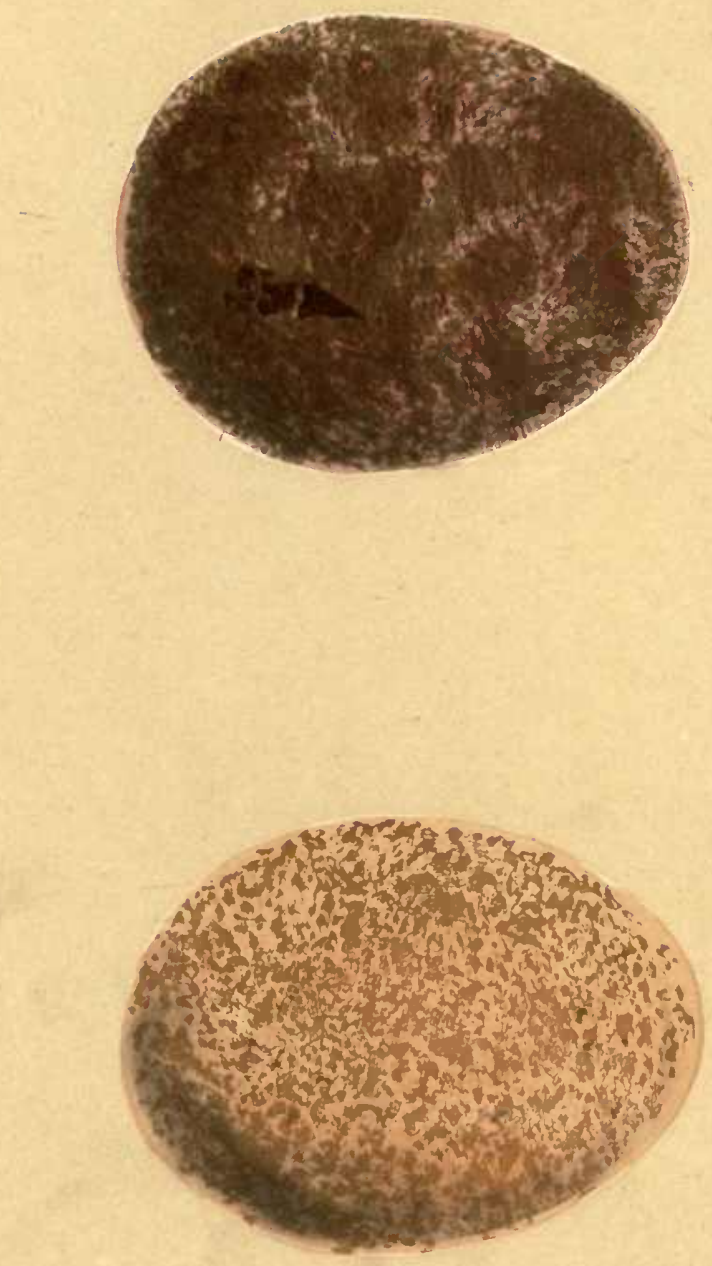


\section{JER-FALCON.}

PLATE XII.

$\begin{array}{ll}\text { Falco Islandicus, } & \text { Latham. Gmelin. } \\ \text { " Gyrfalco, } & \text { Linndeus. Bewick. } \\ \text { Gyrfalco candicans, } & \text { Fleming. }\end{array}$

THe noble and magnificent Jer establishes its eyrie not only on the highest and most inaccessible rocks, but also occasionally in cliffs that are of lower elevation, both those of the sea coast and those of inland lakes; and, like so many other birds, when engaged in the task of incubation is particularly daring in attacking any aggressor.

The nest is composed of sticks and roots, and is lined with wool, moss, sea-weed, or probably any soft substance suitable for the purpose which the builders can procure. The Jer-Falcon is supposed to be in the habit of appropriating to itself the deserted nest of other birds.

The eggs are described as being of a light yellowish brown colour, dotted with rusty red, with here and there an occasional patch of the same; or dull white, mottled all over with pale reddish brown. They are said to be two or three in number, and of an extremely elegant appearance.

One variety is of a reddish cast, mottled all over, particularly at the larger end, with dashes of a brighter hue, with a very few occasional spots of yellowish white.

A second is of a somewhat similar appearance, but with the general colour more blended, and the marks assuming more the form of streaks, waved in different directions; a few of those near the smaller end being darker than the rest.

A third is of very much the same character as the last mentioned, but its colour is changed to greenish brown, the markings being darker shades of the same.

A fourth assumes somewhat of a whitish appearance, marbled slightly over, especially at the smaller end, with light orange brown. 



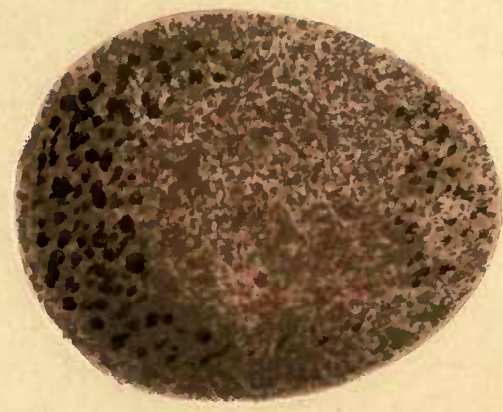




\title{
PEREGRINE.
}

\author{
PEREGRINE-FALCON.
}

PLATE XIII.

\begin{abstract}
Falco peregrinus, " communis,

Latham. Fleming.

Latham. Selby.
\end{abstract}

THIs 'Falcon gentil,' a noble bird, builds its nest early in the spring, and the young are hatched about the first week in May. The old situation is resorted to from year to year.

The nest is flat in shape, and is placed on a projection, or in a crevice of some rocky cliff. It is fabricated of sticks, sea-weed, and such like materials, and lined more or less with hair. Sometimes the bird will appropriate the old nest of some other species, and sometimes be satisfied with a mere hollow in the bare rock, with occasionally a little earth in it.

The eggs are two, three, four, or, though but rarely, five in number, and rather inclining to rotundity of form. Their ground colour is light russet red, which is elegantly marbled over with darker shades, patches, and streaks of the same, but they vary much according to the age of the bird.

One variety has the ground colour a rich yellowish brown, elegantly mottled over with blots of very deep red, and here and there a little pink.

A second has the ground colour the same, but of a lighter shade, and with only a few of the red markings, and lighter in hue.

A third is of a general light orange yellow ground, with a few patches of a darker shade of the same.

A fourth is also of light appearance-a combination of very light yellow, light green, and light orange. 


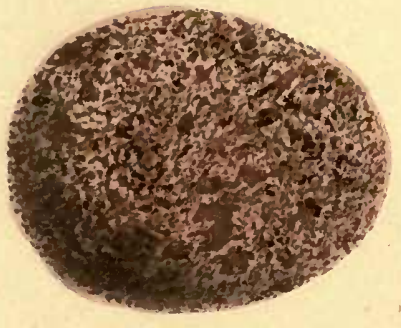




\section{HOBBY.}

PLATE XIV.

$\begin{array}{cll}\text { Falco subbuteo, } & \text { Pennant. Montagu. } \\ " & \text { " } & \text { Bewick. Fleming. } \\ " & \text { Seliz. Jenyns. Gould. }\end{array}$

The Hobby builds in the trees of woods and forests, generally among the topmost branches, but sometimes in a hole of the trunk. In the former case a preference is given to isolated fir or other plantations, as affording at the same time a less likelihood of disturbance, a better view of approach from all sides, and a supply of the several kinds of food on which the bird lives. It has also been known to build on the ledges of steep precipices and mountains. The same pair will return to the same breeding-place from year to year, if not disturbed.

The nest is built of sticks, and is lined with moss, hair, and other such materials. Occasionally the forsaken tenement of some other species of bird is made to serve the purpose of one of its own fabrication, and it frequently avails itself of that of the Carrion Crow, or of the Magpie.

The eggs are laid about the first week in June, and are two, three, or four in number; some say that the former, and others that the latter is the more frequent amount; they are of rather a short and oval shape, and of a dingy white, or bluish white ground colouring, much speckled all over with reddish or yellowish brown. Some are thus mottled with olive green.

One variety is of a dull brown, with a very slight tinge of dull orange, mottled all over with small specks and marks of different darker shades, a few of them much deeper than the rest.

A second, a very elegant egg, is the faintest orange yellowish brown on a white ground, minutely dotted and speckled all over with darker markings of the same, a few of them much darker than the rest. 
A third is light yellowish brown, but darker than the last mentioned, marked in the same way, but more suffused.

A fourth is of a decided reddish cast, but light and clear in colour, and elegantly marked all over with small darker streaked spots of reddish brown.

Mr. Hewitson describes the eggs generally as being very much like some of those of the Kestrel, as well as those of the Merlin; but says that they are larger than either; of a pinker hue, less suffused with colour, and marked with fewer of the small black dots which are scattered over the surface of the others.

The young remain for some time in the neighbourhood of the nest, until they have gradually learned to cater for themselves. 


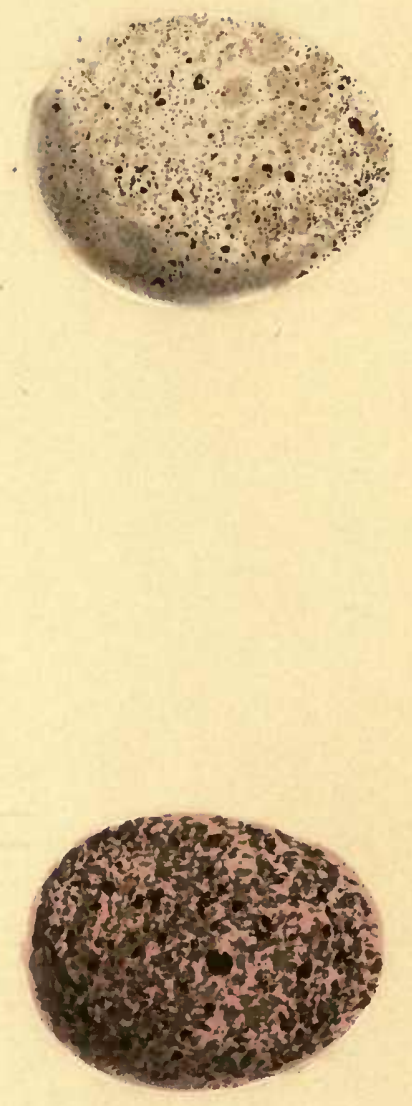


\section{ORANGE-LEGGED HOBBY.}

PLATE XV.

Falco rufipes,

Falco vespertinus,
Bechstein.

Gmelin. Linneuds. Latham.

The nest of the Orange-legged Hobby is said to be built in the hollows of trees, and it is also asserted that use is sometimes made of that of a Magpie or other bird.

The eggs seem to vary considerably in colour:-

One is rather light brown, marked all over with darker confluent markings of the same.

A second is of a fine light russet orange hue with a tinge of yellow, marked in the same way.

A third is of a light dull yellow, minutely speckled all over with a slightly darker colour.

A fourth is dull white, with irregular indistinct dots all over it, and a few of a larger, darker, and more distinct character, and the lower end nearly covered with the same.

The first figure on the plate is from a specimen in the collection of H. F. Walter, Esq., of Russell Square, London. 


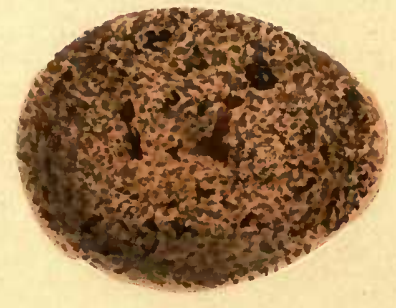




\section{MERLIN.}

PLATE XVI.

Falco cesalon,

"s
Pennant. Montagu.

Bewick. Fleming.

The female Merlin sits close at first, but if disturbed or alarmed more than once, becomes extremely shy. The male takes up a position near at hand, on the top of some eminence, from whence he can perceive the approach of any intruder, of which he gives notice by shrill cries of alarm.

The nest is generally, in this country at least, built on the ground, on open moors or heaths; frequently on the side of a ravine, in a tuft of heath, or projection of a rock or bank; and when this is the case, is composed of very scanty materials-a few sticks, with heather, grass, or moss-the bare ground almost sufficing for the purpose. In other countries it appears, occasionally at all events, to be built in trees, and is then made of sticks, and lined with wool. In the Orkney and Shetland Islands it is placed among precipitous and inaccessible rocks. Montagu says that an instance has been known of a Merlin building in a deserted Crow's nest; and I have no doubt that such occurrences are by no means rare.

The eggs are three, four, or five in number; Bewick says six, and Temminck five or six. They are bluish white, blotted, particularly at the thicker end, with deep reddish brown, or greenish brown: they vary, however, much in colour. Some of the varieties are often similar to those of the Kestrel or Peregrine, others to those of the Sparrow-Hawk, but still more to those of the Hobby. They are perhaps rather smaller than the former, and also, in this variety, browner in colour, and more closely spotted with small dots. One has been known of a rich crimson red, blotted with a darker shade of the same. 

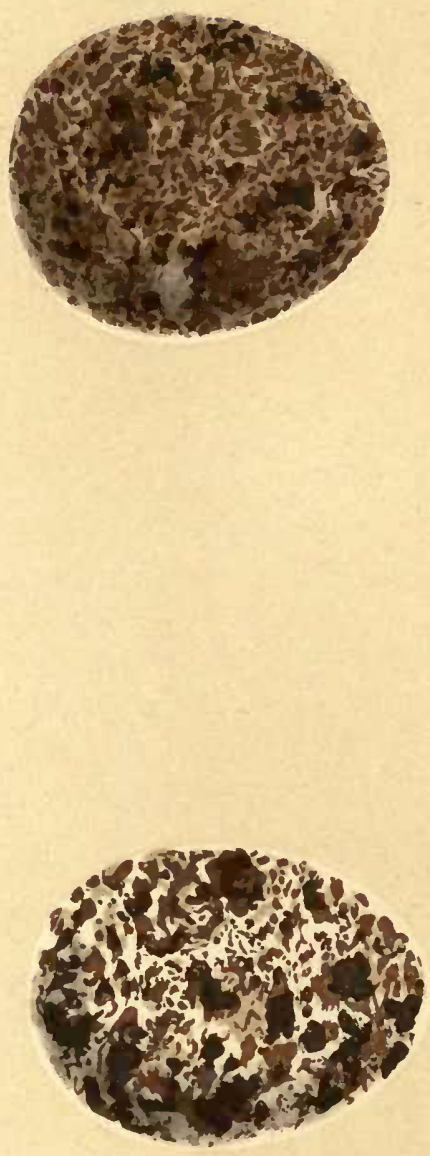


\section{KESTREL.}

WINDHOVER. STONEGALL. STANNEL HAWK.

PLATE XVII.

Falco Tinnunculus, Accipiter alaudarius,
Montagu. Selub.

Brisson.

Some pairs of Kestrels seem to keep together throughout the winter. About the end of March is the period of nidification. The young are hatched the latter end of April; and are at first fed with insects, and with animal food as they advance towards maturity.

I am indebted to my obliging friend, the Rev. John William Bower, Rector of Barmston, in the East-Riding, for the first record, that I am aware of, of the breeding of the Kestrel in confinement. The following is an extract from his letter dated November the 30th., 1849, relating the circumstance:- 'A pair of Kestrels bred this summer in my aviary. The female was reared from a nest about four years ago, and the year after scratched a hole in the ground, and laid six or seven eggs, but she had no mate that year. Last winter a male Kestrel pursued a small bird so resolutely as to dash through a window in one of the cottages here, and they brought the bird to me. I put him into the aviary with the hen bird, and they lived very happily together all the summer, and built a nest or scratched a hole in the ground, and she laid five eggs, sat steadily, and brought off and reared two fine young ones.'

The nest, which is placed in rocky cliffs on the sea-coast, or elsewhere, is also, when it suits the purpose of the bird, built on trees, in fact quite as commonly as in the former situations; sometimes in the holes of trees, or of banks, as also occasionally on ancient ruins, the towers of churches, even in towns and cities, both in the country

vol. I. 



\section{LESSER KESTREL.}

PLATE XVII.*

\author{
Falco Tinnunculoides, \\ " cenchris, \\ " Tinnuncularis, \\ " gracilis, \\ Cenchneis cenchris,
}

Natterer. Temminck.

NaUmann.

Vieillot.

Lesson.

Buonaparte.

THE Lesser Kestrel builds among ruins, or in the crevices of mountain rocks.

The eggs are said to be three or four in number, of a reddish white ground-colour, with a great number of little points and spots of a brick-dust red, commingled together and mixed with other small brown spots.

There are several varieties of them. 



\section{GOSHAWK.}

PLATE XVIII.

\begin{abstract}
Aster palumbarius, Falco palumbarius, Buteo palumbarius, Accipiter palumbarius,
\end{abstract}

Selby. Gould.

Pennant.

Fleming.

JENYNS.

The nest of the Goshawk is said to be built in tall fir or other trees, near the trunk, and to be large in size, flat in shape, and composed of sticks, grass, and moss, loosely put together; probably the coarser materials are most made use of.

This bird, like others of its tribe, is believed to be frequently in the habit of occupying the same nest for several years in succession, making the necessary repairs from time to time. Though reckoned among the ignoble Falcons, as a short-winged species, yet its great power and strength must doubtless give it a secure occupancy of its stronghold, safe against all hostile intruders of its own-the feathered kind. Its motto might well be,

'Who checks at me, to death is dight.'

Mr. Hewitson says that the nest 'is placed in some high tree in the interior of the woodland, except in those parts which are cleared, and free from timber.'

During the time that the female is sitting, she is fed by the male.

The eggs, which are hatched about the middle of May, after an incubation of about three weeks, are said to be from two to five in number. They are greenish or bluish white, often with, and sometimes without, or nearly without, a few streaks or spots of 

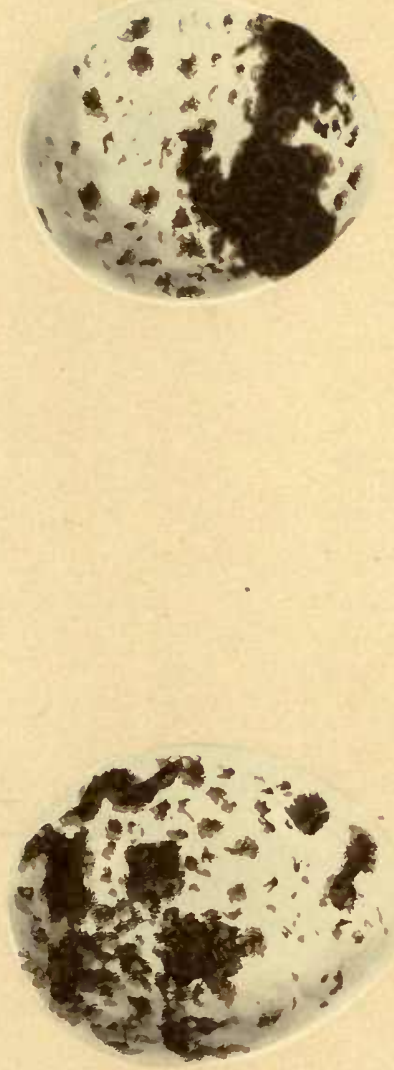


\section{SPARROW-HAWK.}

PLATE XIX.

Accipiter fringillarius,

Falco nisus,

Buteo nisus,
Shaw. Selby.

Linnaus. Latham.

Fleming.

The Sparrow-Hawk commences its nidification in April: the young are hatched after an incubation of three weeks.

The nest, which has frequently been the previous tenement of a Crow, Magpie, or other bird, is built in fir or other trees, or even in bushes of but moderate height, as also in crevices or on ledges of rocks, and on old ruins. It is large in size, flat in shape, and composed of twigs, sometimes with, but often without a little lining of feathers, hair, or grass. This species seems however to be but seldom its own architect, but the samo nest is sometimes resorted to from year to year; in fact it is the opinion of Mr. Hewitson, no mean one, that the Falcons very rarely make a nest for themselves. An action of ejectment is commenced in person against some other tenant at its own will of its own property-no notice to quit having previously been given; and, notwithstanding this legal defect, forcible possession proves to be nine points of the law, and 'contumely' is all the satisfaction that 'patient merit of the unworthy takes.'

The eggs, which are of a very 'distingué' appearance, are of a rotund form, bluish white in colour, much blotted, particularly at the base, with very deep reddish brown, and from three to five or six, or even seven in number. They vary, however, very frequently in their markings, which, in some instances, are obscure and indistinct; and in others, the dark blots are at the smaller instead of at the larger end. 
One variety is of a pale dull olive brown, with a large patch of a dull rich brown of two shades near the base, and a few specks of lighter brown.

A second is dull white, mottled about the smaller end with patches and specks of dark rich brown, of which there are a few scattered here and there over the remainder.

A third is dull white, with a patch of dark brown at the smaller end, and a few small blots and specks near it.

A fourth is clearer white, with a rich irregular belt of brown near the thicker end.

N. Rowe, Esq., of Worcester College, Oxford, has written me word of five procured by him in the year 1851, from a nest, which were quite white and spotless. He obtained the bird at the same time. 


\section{MARSH HARRIER.}

MOOR HARRIER. MOOR BUZZARD. WHITE-HEADED HARPY. PUTTOCK. DUCK HAWK.

PLATF XX.

$\begin{array}{ll}\text { Circus rufus, } & \text { Brisson. Selbr. } \\ \text { Fulco cruginosus, } & \text { LINNeUs. PenNant. } \\ \text { Falco arundinaceus, } & \text { Bechs'tein. }\end{array}$

Towards the end of the month of March the nidification of this species commences, and incubation in April: the young are hatched in May.

The nest is usually built among the high reeds which fringe the margin of the lake, pond, or swamp; in a tuft of rushes, fern, or furze; occasionally on a mound, at the edge of a bush, on the top of the stump, or in the hollow of the branches of some tree in any of the former situations. It is a rude fabrication, and is composed of sticks, with reeds, flags, sedge, rushes, grass, or leaves," sometimes forming a mass a foot and a half above the ground.

The eggs are from three to five in number, slightly tapered at one end, and generally perfectly white, or white with a slight tinge of blue: some are very faintly and slightly blotted with pale green, and others with pale brown. Bewick says that they are irregularly spotted with dusky brown; and Mr. Macgillivray describes some he had seen which had a few faint light brown marks. 





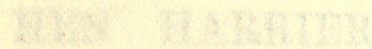

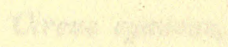

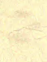

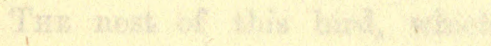

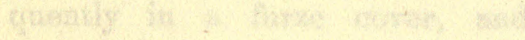

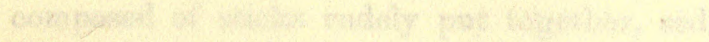

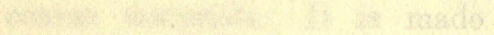

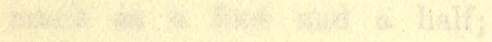

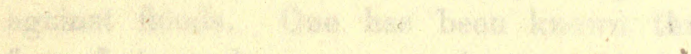

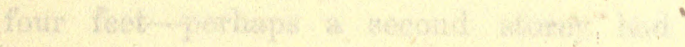

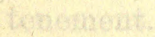

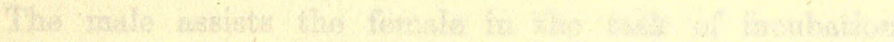

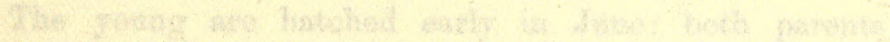

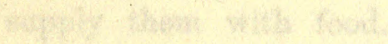

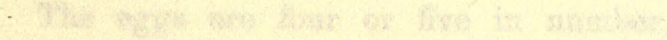

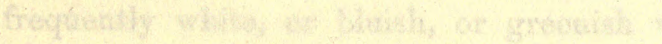

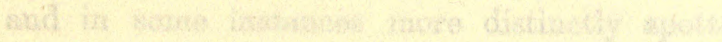

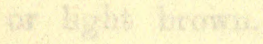

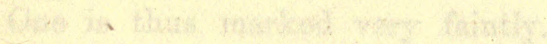

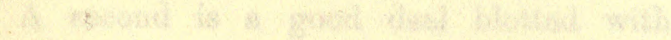

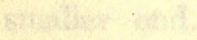

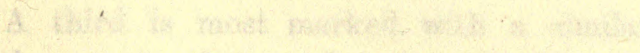

Whith 2020

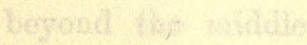

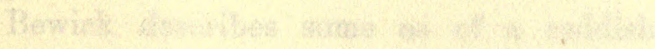

$\sin 2015$ 



\title{
HEN HARRIER.
}

\author{
PLATE XXI.-FIG. I.
}

Circus cyaneus,

Fleming. Selby.

The nest of this bird, which is built on open wastes, and frequently in a furze cover, and placed on or near the ground, is composed of sticks rudely put together, sedge, reeds, flags, and other coarse materials. It is made of considerable height, sometimes as much as a foot and a half; possibly, in such cases, a safeguard against floods. One has been known thus raised to the height of four feet-perhaps a second storey had been added to a former tenement.

The male assists the female in the task of incubation.

The young are hatched early in June: both parents are said to supply them with food.

The eggs are four or five in number, sometimes six; and most frequently white, or bluish, or greenish white, often slightly marked, and in some instances more distinctly spotted with yellowish brown, or light brown.

One is thus marked very faintly.

A second is a good deal blotted with very pale brown at the smaller end.

A third is most marked with a similar colour at the larger end, with a sort of irregular bar of the same round the egg, a little beyond the middle.

Bewick describes some as of a reddish colour, with a few white spots. 


\section{MONTAGU'S HARRIER.}

PLATE XXI.-FIG. II.

\section{Circus Montagui,}

Falco hyemalis,

Falco cineraceus, cinerarius, and cinerareus, Buteo cineraceus,
YARRELL.

Pennant.

Montagu.

Fleming. Jenyns.

THE nest of this species is built on the ground among long grass, heather, rushes, or fern, and is composed of moss, hay, or grass, or even formed by a mere hollow in the earth.

The young have been found seated on the ground, near the nest, before they were able to fly.

The eggs, which are white, are from three to five in number. 



\section{SHORT-EARED OWL.}

WOODCOCK OWL. SHORT-HORNED OWL. HAWK OWL. MOUSE HAWK.

PLATE XXII.-FIG. I.

Strix brachyotos,

" ulula,

Otus brachyotos,
Montagu. Bewick.

LATHAM.

Selby. Gould.

The nest of the Short-eared Owl is placed on the ground among long grass, heather, rushes, or fern, and is composed of moss, hay, or grass, or even formed by a mere hollow in the earth.

The young have been found seated on the ground near the nest before they were able to fly.

The eggs are white, of a rotund form, and from three to five in number. 


\title{
LONG-EARED OWL.
}

LONG-HORNED OWL.

PLATE XXII.-FIG. II.

\author{
Strix otus, \\ Linnaus. Latham. \\ Otus vulgaris, \\ Fleming. Selby.
}

THE nidification of this species commences in March.

Other birds' nests, such as crows, magpies, and ring-doves, are generally, if not always, fitted up by the one before us as its domicile, by flattening them and lining them with a few feathers or a little wool. It sometimes even locates itself in that of a squirrel, and is not deterred by its not being far from the ground.

The eggs, which are of a round shape, and white, are generally two in number, but sometimes three or four, and some writers say five. They are laid about the end of March or the beginning of April, by the latter end of which month the young are hatched. 




\section{EAGLE OWL.}

GREAT OWL. GREAT HORNED OWL. GREAT EARED OWL.

PLATE XXIII.-FIG. I.

$\begin{array}{ll}\text { Strix bubo, } & \text { Linneus. Montago. } \\ \text { Bubo maximus, } & \text { Seliby. GouLd. }\end{array}$

Nidification with this species commences the latter end of March. Only one brood is produced in the year. The female sits about five weeks. Incubation begins in April, and the young are hatched in May.

The nest is very large, and is placed on rocks or old ruins, amid the desolate sterility of the bleak hill or the wild unsheltered mountain. It is composed of branches and sticks, and is lined with leaves and straw: occasionally a hollow in the bare earth answers the purpose. The same eyrie is frequently resorted to year after year.

The eggs are two or three in number, white or bluish white, and, like those of all the Owls, of a rounded form, and, as described by Meyer, of a rough chalky appearance. 


\title{
SCOPS-EARED OWL.
}

\author{
LITTLE HORNED OWL.
}

PLATE XXIII.-FIG. II.

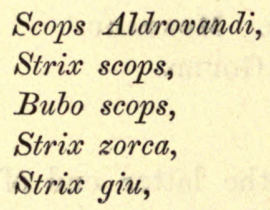

Fleming. Selby.

Linneus. Montagu.

JenYns.

Latham.

LATHAM.

The nest of the Scops-eared Owl is generally placed in the hole of a tree or a rock, and also in heather. Selby says that it constructs no nest; and this is very likely the case in some instances at all events: possibly that of some other bird is made use of.

The eggs are white, and from two to four or five, or, according to Selby, as many as six in number. 



\section{SNOWY OWL.}

PLATE XXIV.-FIG. I.

Strix nyctea,

Surnia nyctea,

Noctua nyctea,
Montagu. Bewick.

Selby. Gould.

JENYNS.

THE nest of this noble bird, whose motto might well be that of another noble family, 'Gripe Griffin, hold fast,' is made on the ground, or upon rocks, though sometimes it is said, in trees, and is composed of branches.

The eggs are white, but by Veillot said to be spotted with black, and two, three, or four in number, of which only two are thought to be in general hatched. 


\section{TAWNY OWL.}

BROWN OWL.

PLATE XXIV.—FIG. II.

\author{
Ulula stridula, \\ Strix stridula, \\ " aluco, \\ Syrnium aluco,
}

SELBY.

Linnaus.

Latham.

Jenins. Temminck.

THE nidification of this bird commences in March.

The nest, if it deserves the name, is formed of a few soft feathers, a few straws, or a little moss, sometimes merely of the decayed wood in the hollow of the tree in which it is placed. One has been observed so low down that a person could see into it from the ground. Occasionally it is built in rocks, sometimes, it is said, in barns and the like buildings, or even in the deserted nests of other birds, such as Buzzards, Crows, and Magpies. The young are hatched in April. They continue to perch among the branches of the trees in the neighbourhood of the nest before finally taking their leave of it, and are fed during the interval by the parent birds.

The eggs are white, and from two or three to four or five in number. The first is sat on as soon as laid, and the young are hatched in about three weeks. They are blind for some days, and their red eyelids look as if inflamed. 



\section{WHITE OWL.}

YELLOW OWL. BARN OWL. SCREECH OWL.

GILLI-HOWLET. HOWLET. MADGE OWL. CHURCH OWL. HISSING OWL.

PLATE XXV.-FIG. I.

\section{Strix flammea, Aluco flammeus, \\ s6 minor,}

Pennant. Montagu.

Fleming.

Aldrovandus.

The White Owl builds its nest for the most part in old ruined and deserted, as well as in existing buildings, chimneys, eaves, or mouldering crevices, barns, dove-cotes, church-steeples, pigeon-lofts, and, but very rarely, in hollow trees.

The nest, if one be made at all, for oftentimes a mere hollow serves the purpose, is built of a few sticks or twigs, lined with a little grass or straw, or, though but seldom, with hair or wool; and this is all that the bird fabricates, and that to but a small extent either of bulk or surface.

The eggs are white, and of a round shape, generally two or three, but sometimes as many as five or six in number, which may be accounted for by the ascertained fact that they will sometimes lay a first, second, and third clutch of two eggs each. 


\section{LITTLE OWL.}

LITTLE NIGHT OWL.

PLATE XXV.-FIG. II.

$$
\begin{aligned}
& \text { Strix passerina, } \\
& \text { " nudipes, } \\
& \text { " dasypus, } \\
& \text { Noctua passerina, } \\
& \text { " nudipes, }
\end{aligned}
$$

Linnaus. Latham. Nillison. JaRDINE. Meyer. Jenyns. Selby. GouLd.

LiKe the rest of the Owls, this one builds early in the spring. The nest, so far as one is made, is placed in chimneys, and other parts of buildings; in pine and other trees, about half way up; as also in osier beds.

The eggs are from two to five in number, and white. The male takes his turn in sitting on them. They are said by Mr. Hewitson to vary in size and shape.

The young are hatched in fourteen or fifteen days. 


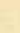





\section{TENGMALM'S OWL.}

TENGMALM'S NIGHT OWL.

PLATE XXVI.-FIG. I.

Strix Tengmalmi, " funerea, Noctua Tengmalmi,
Gmelin. Latham.

LinNaUs.

JENYNS.

THese Owls are said to breed in holes of trees, half way up, and, as being deficient in such an 'exhibition of industry,' to make no manner of nest, or only to use a little grass for the purpose.

The eggs are white, and two in number.

The specimen from which the original drawing, by William Richard Fisher, Esq., was taken, is in the collection of H. F. Walter, Esq., of Russell Square, to whom this work is very greatly indebted. 


\title{
HAWK OWL.
}

\author{
CANADA OWL.
}

PLATE XXVI.-FIG. II.

\section{Strix funerea, \\ Sturnia funerea, \\ Noctua funerea,}

Temminck.

GouLd.

JenYNS.

THe nest is built in a tree, and is composed of sticks, grass, and feathers.

The eggs are white, and, like those of the Owls generally, of the dual number. 

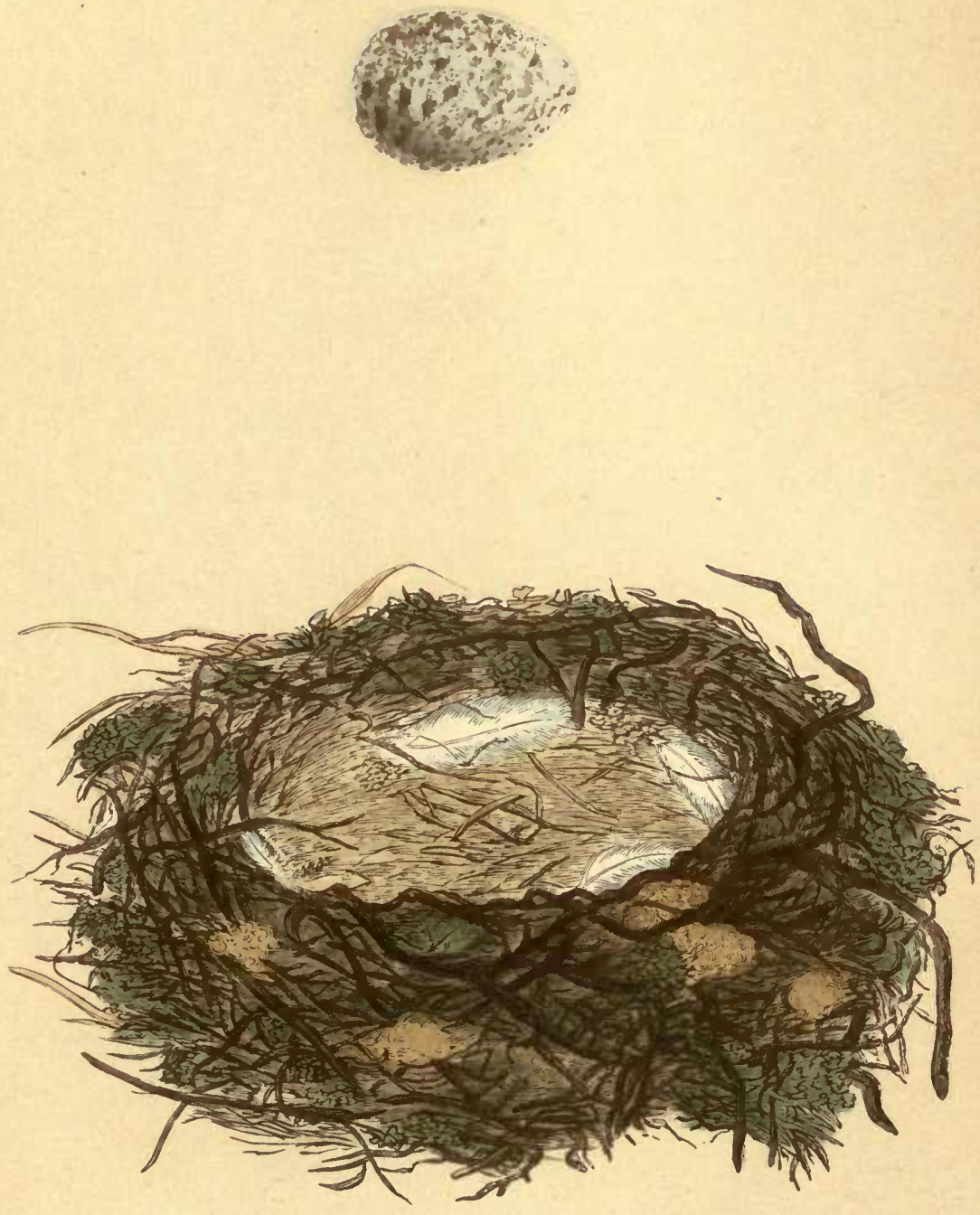



\section{GREY SHRIKE.}

GREAT GREY SHRIKE. GREAT SHRIKE. ASH-COLOURED SHRIKE. GREATER BUTCHER BIRD. MURDERING PIE. SHRIKE.

SHREeK. CINEREOUS SHRIKE. MATTAgESS. MOUNTAIN PIE. HORSEMATCh.

PLATE XXVII.

Lanius excubitor, 66
Linnaus. Pennant. Montagu. Bewick.

The nest of the Grey Shrike is built in trees, hedges, or bushes, some height above the ground. It is large and ill concealed, but well put together, and is composed of grass, hay, ling, small roots, stalks, and moss, and lined with wool or down, or the finer parts of the outside materials.

When the hen is sitting, the male is very vociferous if any one approaches the nest, and when the young are hatched, both exhibit a clamorous anxiety which often defeats their object, and betrays their callow brood to the callous bird-nester. The young, indeed, themselves join in the untoward imprudence.

The eggs are four or five, and sometimes it is said, as many as six or seven in number. They are of a greyish, bluish, or yellowish white ground, spotted at the thicker end with different shades of grey and light brown, forming an irregular band-the character of those of all the Shrikes.

One variety is of a dull yellowish green all over, slightly marked with specks and a few blots of a darker shade of the same.

A second is of a pale yellowish white ground-colour, spotted all over with spots, dots, and oblong marks of a yellowish green colour, and the base a good deal marked with the same. 
A third is of a pale bluish ground-colour, with a few minute dots of yellowish green, and some larger patches of the same, principally at and towards the larger end.

A fourth is of a neutral-tint ground-colour, much marked all over with dull yellowish orange.

Alfred Newton, Esq., of Elvedon Hall, Thetford, writes me word that the eggs sometimes resemble those of the Magpie, and that he has seen one of a bluish white ground-colour, with a few dark and well-defined spots. The same gentleman has very obligingly forwarded to me a drawing of the nest of this species, from which the plate is taken. 


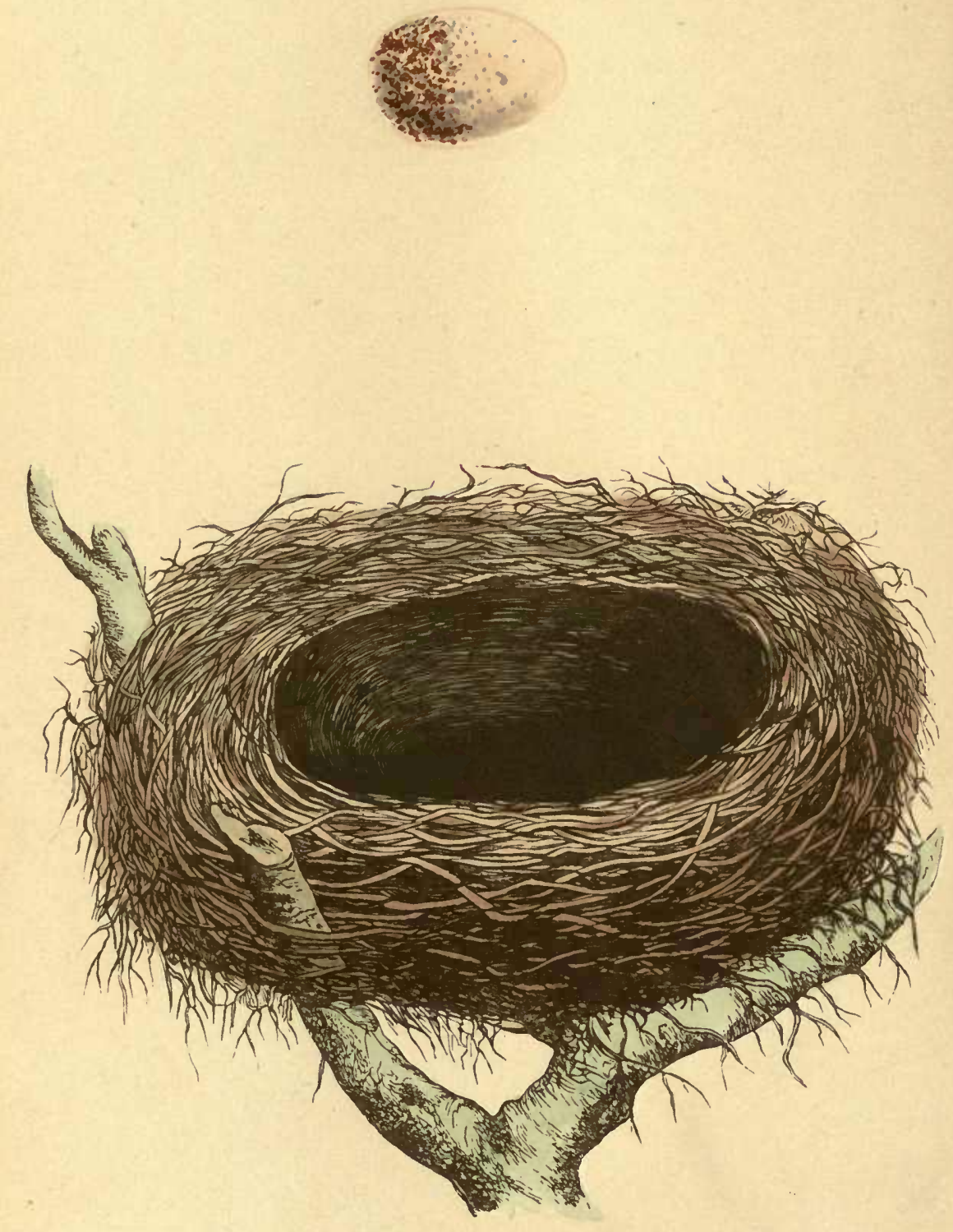




\title{
RED-BACKED SHRIKE.
}

\author{
CHEETER. FLUSHER.
}

LESSER BUTCHER BIRD. MURDERING PIE. JACK BAKER.

WHISKEY JOHN. NINE KILLER.

PLATE XXVIII.

Lanius collurio,

Pennant. Montagu. Bewick.

The nest is placed, without much attempt at concealment, in a hedge or bush. It is large for the size of the bird, being from six to seven inches across, somewhat deep like a cup, and is composed of the stalks of plants, grass, wool, and moss. It is lined with small roots, and occasionally, it is said, with hair. The edge of the top rather projects over the side.

G. Grantham, Esq., of East Shalford, near Guildford, has favoured me with the egg of this bird, which I have often in former years taken myself, more or less spotted with red. In general they are pale reddish white, spotted with two shades of darker red and reddish brown, and the base is encircled by a belt, formed of an irregular conglomeration of the same. Occasionally they are pale bluish white, or white, and sometimes greenish white, spotted with brown and grey, or rufous; they are five or six in number. The band already alluded to has been in some cases found at the narrow end. They vary also in size and shape.

One variety is of a very pale pink colour, spotted over, but much the most in the place of the band with fine bright red.

A second is very pale orange pink, with a few faint spots all over of rather a darker shade of the same, obscurely traceable in the way of a belt towards the larger end.

voL. I. 
A third is dull white, with a zone of a few spots of dull yellowish and dull green.

A fourth is pale greyish. white, spotted over, mostly around and near the middle, with small spots and specks of yellowish green.

A fifth is light grey, with a zone of pale greenish yellow spots, run and streaked together in the way of a zone or belt, with a very few others of a paler shade here and there. 

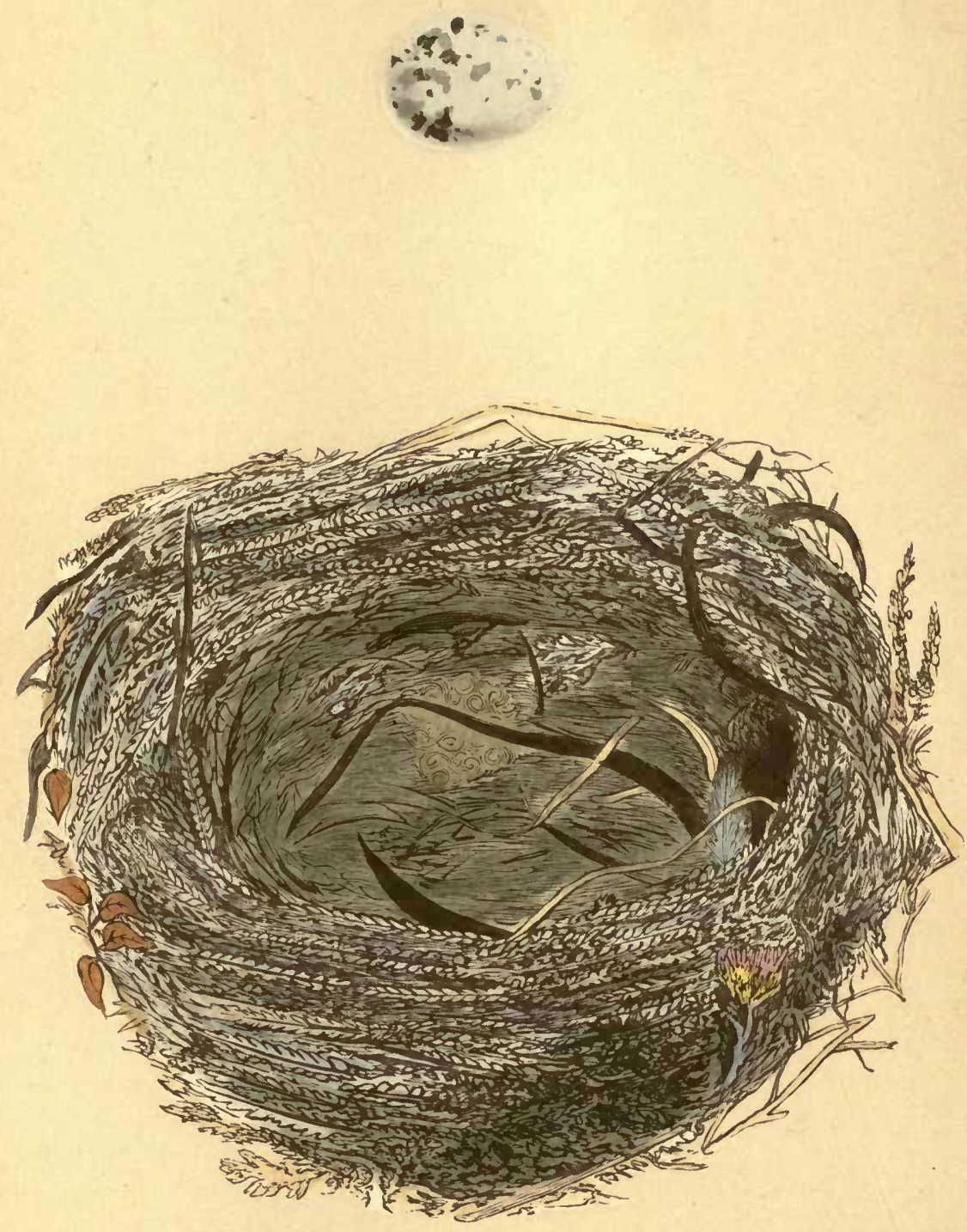


\section{WOODCHAT.}

WOOD SHRIKE. WOODCHAT SHRIKE.

\section{PLATE XXIX.}

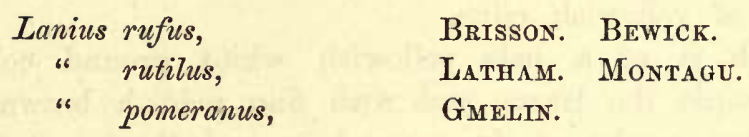

The nest is said to be placed in the angle of the branches of a tree - a preference being given to the oak. It is composed of sticks, wool, and moss, and lined with wool and fine grass.

Both birds sit on the eggs in turns.

Alfred Newton, Esq., of Elvedon Hall, Thetford, has favoured me also with a drawing of the nest of the Woodchat, from which the accompanying plate is taken. He describes it as particularly large for the size of the builders, being upwards of three inches and a half in diameter inside, and nearly two inches deep. The outworks of this nest are composed of a flowering plant, the stalks of which are laid parallel to one another, which give the nest a singular appearance. A good deal of wool is used in its construction, and it is lined with dry grass mingled with a few small feathers.

It has been stated that this species uses aromatic herbs in the construction of its nest.

The eggs are described by Mr. Hoy as being four or five in number, and varying much in marking, as well as in size and shape. The zone is not so frequent, or rather not so conspicuous, as in those of the Red-backed Shrike, but still it is irregularly traceable in most instances. In some the ground colour is pale blue; in others dull white, with a band of rust-coloured spots round the lower end; in others the whole surface is more or less spotted with a lighter colour. 
Mr. Hewitson describes one from the fine collection of the Messrs. Tuke, of York, in which the spots, which are large, and deep in colour, of a brown or neutral tint, are scattered equally over the whole surface.

A second variety is light bluish grey, with some large and some small dashes and spots of olive about the space between the centre and the base, and a few specks of the same elsewhere.

A third is pale yellowish white, with spots of yellowish olive irregularly distributed around and about the centre.

A fourth is pale yellowish white, with a few spots of yellowish around the middle, tending towards the base.

A fifth pale yellowish, with numerous spots of brownish red, chiefly around the centre, but a few over the remainder of the egg.

A sixth is of a very pale yellowish green ground colour, spotted all over, but principally in the way of a belt near the larger end with spots of yellowish olive.

A seventh is of a pale yellowish white ground colour, richly marked towards the larger end with fine reddish brown spots, and a few minute specks of the same here and there. 


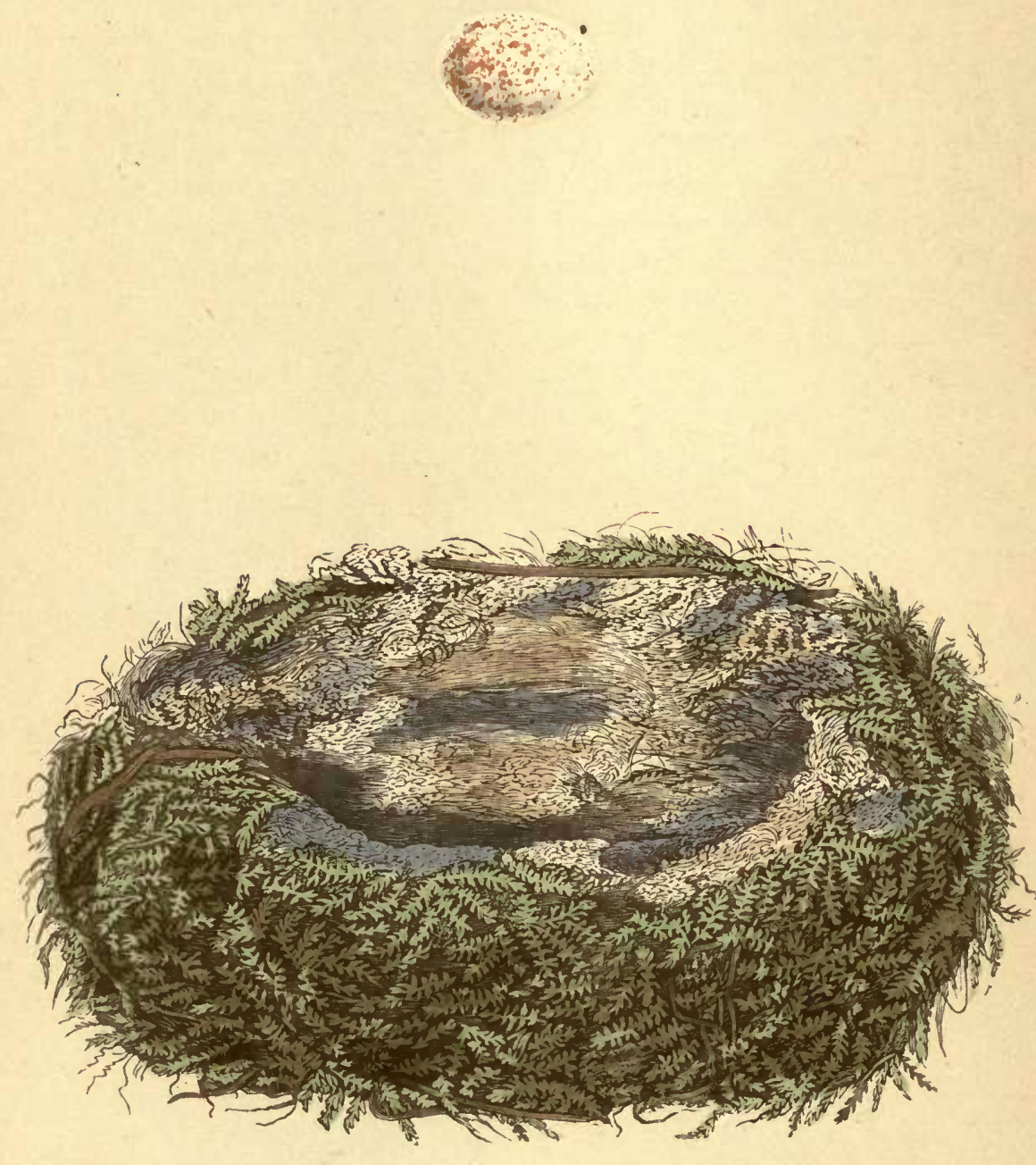


\section{GREAT TIT.}

OXEYE. BLACK-CAP. GREAT TITMOUSE. GREAT

BLACK-HEADED TOMTIT. TOM COLLIER. SIT-YE-DOWN.

PLATE XXX.

Parus major,

Pennant. Montagu. Bewick.

THE nest is usually made in a hole of a tree or of a wall, or crevice of a rock; sometimes the forsaken nest of a Crow or Magpie is converted into a tenement. Not unfrequently it is placed in a pump either used or unused, the door-way being by the orifice for the handle. Another has been known to build far up among the rafters of a house; one in a window-frame, the entrance being through the opening for the weight; and another under an inverted flower-pot. It is composed of a quantity of moss, feathers, leaves, hair, or other materials loosely compacted. Occasionally the eggs are laid on the dust of the wood alone; and if I may offer a conjecture on the subject, possibly these cases may be when a first nest has been taken or destroyed, and the bird is in a hurry about her second brood. Since writing the above I perceive that Montagu has made a similar suggestion.

The Rev. G. Sowden, of Stainland, near Halifax, Yorkshire, has written me word of his having once found the nest in the wall of a house, exclusively composed of rabbits' fur; all the corners of the hole were filled with it: in the middle was a most exquisitelyformed round hollow, and altogether it was exceedingly pretty and comfortable.

Mr. J. Brain, of Sleights, near Whitby, has obliged me with a nest and eggs of this species, from which the plate is taken. 
The eggs, from six to eleven in number, are pure white, dotted all over irregularly with reddish brown.

One variety is thus much marked at the thicker end, with a few scattered specks over the remainder of the surface.

A second is very elegantly dotted with rather large spots, few in number.

A third is mottled faint orange brown, rather most so at the larger end.

The hen sits closely on them, and the male keeps a station not far off, both of them equally pugnacious in defence of their progeny, the latter uttering loud cries of anger or distress, and the former hissing as she sits.

The young are said, after they have left the nest, not to return to it, but to perch for some time in the neighbouring trees, and to keep together until the following spring. It is somewhat singular that the eggs of this species resemble those of the Nuthatch, to which bird it also has some similarity in the loud tapping noise it occasionally makes against the trunks of trees, and which has been conjectured to be for the purpose of frightening insects out from under the bark. 


\section{,}




$$
4
$$

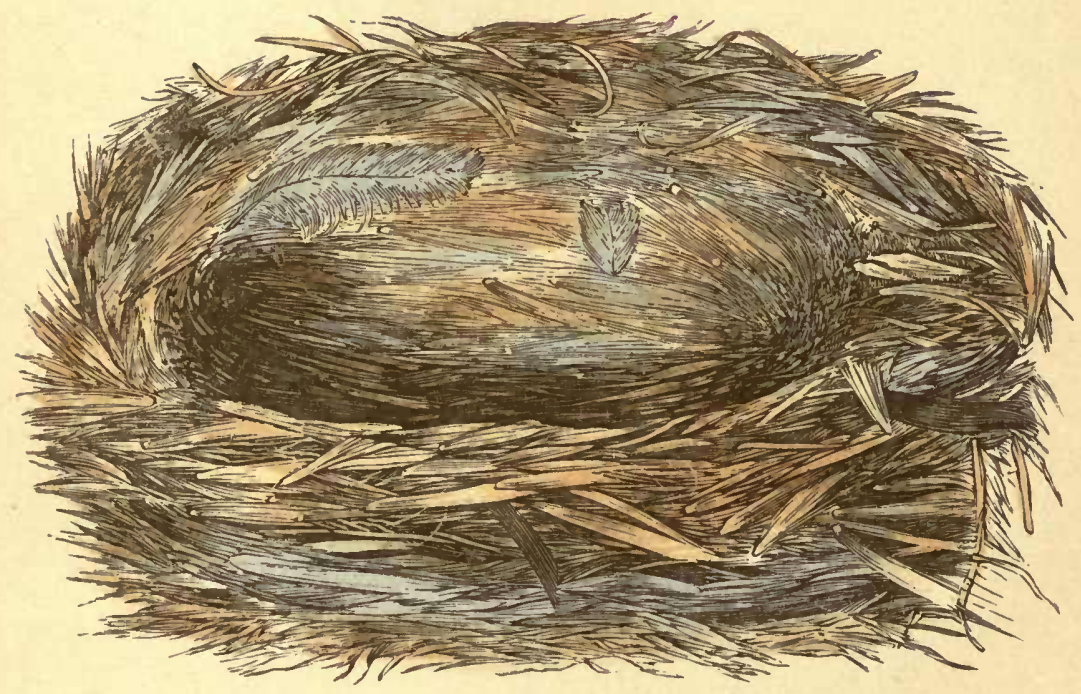




\title{
COLE TIT.
}

\author{
COLE TITMOUSE. COLEMOUSE.
}

PLATE XXXI.

Parus ater,

Pennaxt. Montagu.

THE nest is placed in a hole of a tree, and, according to $\mathrm{Mr}$. Hewitson, at a less height from the ground than that of the other Titmice, even in the hollows about the roots; sometimes in the hole of a wall, or of a bank, or in that of a mouse, rat, or mole: it is made up of moss, wool, hair, fur, and feathers. This bird, like the Oxeye, and doubtless others of its race, will enlarge a hole for its accommodation by removing the pulverised particles of wood which have partially filled or lined it.

Two gentlemen of Rutlandshire, who wish their initials only to appear, $\mathrm{W}$, and $\mathrm{C}$, have favoured me with the nest from which the engraving has been made. It appears to be entirely composed of fine hair and down, with a few thin woody fibres intermixed.

The eggs, from six to eight in number, are like those of its fellows -white, spotted with light red: some have a tinge of yellowish.

Incubation lasts about a fortnight, the male and female sitting by turns; the young are fed principally with caterpillars. Two broods are hatched in the year, of which the first is fledged in May. 

ton

do 


\section{CRESTED TI'T.}

CIESTED TITMOUSE.

PLATE XXXII.

Parus cristatus,

Pennant. Montagu.

The nest, which is composed of grass, moss, or lichens, and feathers, or doubtless any soft materials, is placed in a hole of a tree-the oak being said to be preferred, as also, according to Temminck, in rocks, or in the deserted nests of Crows or squirrels; probably the particulars related of the other Titmice would apply to this one also, as to its location, for a nest examined by Mr. Hewitson was thus scooped out. He writes as follows:- 'When trees are felled in the forests, their trunks are left standing about two feet above ground;' (he is speaking, I should observe, of the forest of Kissingen, in Bavaria,) "and in the decayed wood of one of these a hole was scooped to contain the nest of which I have spoken-just such a situation as would have been chosen by the Cole Titmouse.'

The eggs are from seven to ten in number, white, spotted and speckled, most so at the larger end, with light purple red:

Some with yellowish red.

Some with rich deep brown. 


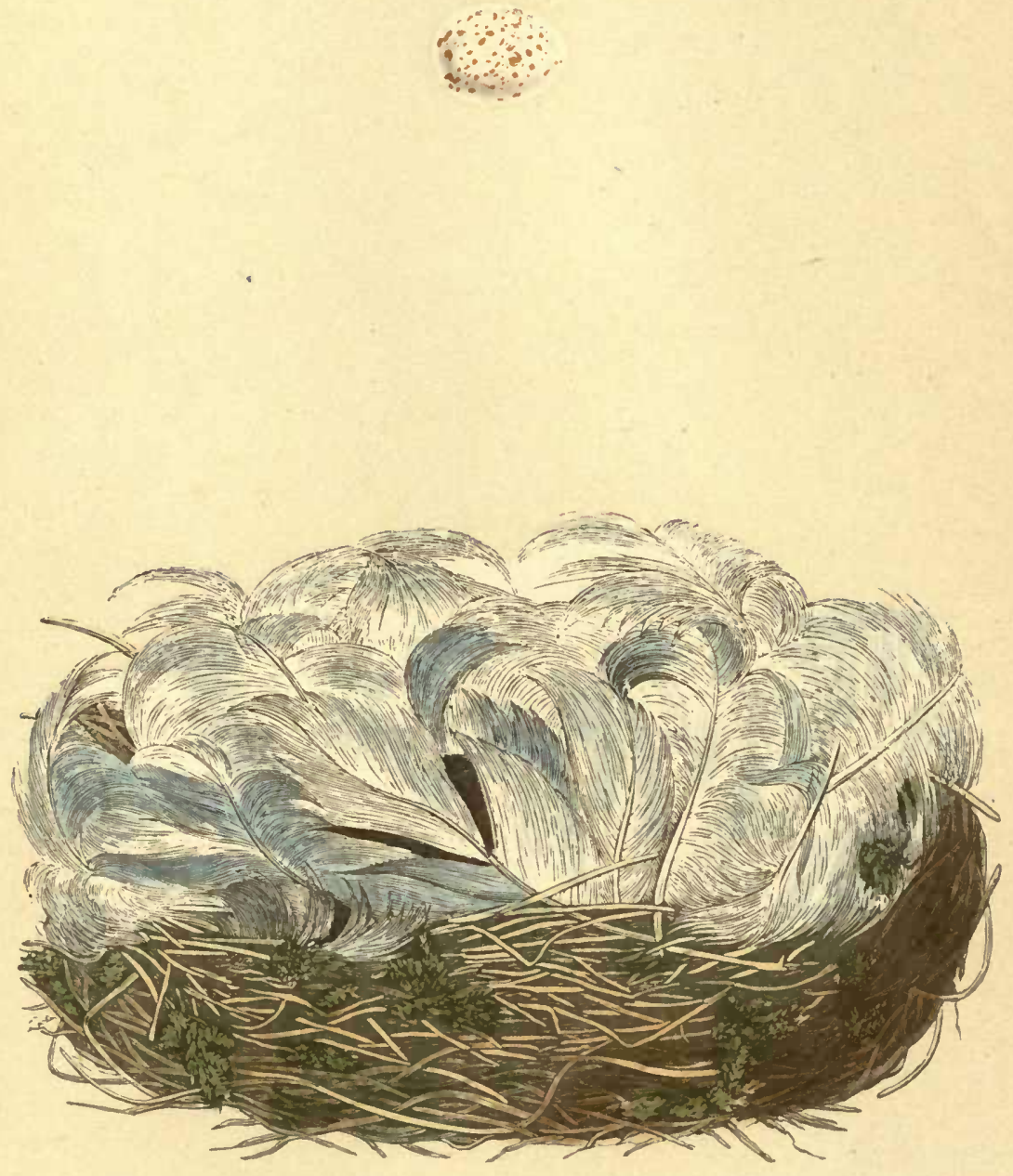



\section{BLUE TIT.}

BLUE-CAP. BLUE titModse. BLUE-BONNet. NUN. TOMTIT. BLUE MOPE. BILLY-BITER. HICKWALL.

PLATE XXXIII.

Parus caruleus,

Montagu. Bewick. Selby.

The nest, which is composed of grass and moss, and lined with hair, wool, and feathers, and is built in March or April, is usually placed in the hole of a tree, about half a dozen, or a dozen feet from the ground, or even close to it. Frequently a hole in a wall is made use of, sometimes the top of a pump, though the bird may be continually disturbed, or the nest even in the first instance destroyed by the action of the handle, the entrance being the cleft for the handle to work in.

Speaking of one instance of this kind, Bishop Stanley says, 'It happened that during the time of building and laying the eggs, the pump had not been in use; and when again set going the female was sitting; and it was naturally supposed that the motion of the pump handle would drive her away. The young brood, however, were hatched safely, without any other misfortune than the loss of a part of the tail of the sitting bird, which was rubbed off by the friction of the pump handle.' And again, 'We knew of another pair of Titmice, which, for several days persevered in inserting, close upon the point of the handle, the materials for a nest; though every time the handle was raised, they were either crushed or forced out, till the patience of the persevering little builders was fairly ex'hausted.' The most extraordinary situation, however, that I have heard or read of for the location of the nest of this, or of any other species of bird, was within the jaws of the skeleton of a man, who had been executed and hung in chains for murder. It would 
almost seem a realization of the fable of our childhood, respecting a somewhat similar locality therein assigned to the nest of Swallows.

Mr. Hewitson records the following, communicated to him by Mr. Heysham, of Carlisle:- 'A few years ago, when upon an entomological excursion, wishing to examine the decayed stump of a tree, which was broken to pieces for that purpose, and the fragments dispersed to a considerable distance by a severe blow, a Blue Titmouse was found sitting upon fourteen eggs, in a small cavity of the root; and notwithstanding the above severe shock, she remained immoveable, till forcibly taken off the nest; sometimes, even if taken off, she will return.' Again, 'An earthen bottle was placed on the garden wall of Mrs. Chorley, of Bolton, near Lancaster; in this a pair of Blue Titmice built their nest, hatched their eggs, and reared their young. There was no cork in the bottle, and the birds had no other way of entrance than through the mouth, going up and down the neck of the bottle every time they carried food to their young ones, all of which, ten in number, were reared without accident, and made their escape unmolested through the neck of the bottle. When they were fairly gone, the bottle was taken down, and the old nest found within. The bottle was fifteen inches deep, and the neck one inch in diameter. I am at a loss to know how the birds could manage to ascend.' Mr. Thompson mentions a similar case in an ornamental jar; and another, communicated by $\mathrm{Mr}$. Poole, in which the male used to feed the female through the neck of the jar.

In the 'York Herald' of June 19th., 1852, I find the following:'So far back as the year 1779, a pair of Blue-caps built their nest, and brought up their young in a large stone bottle, which had been left to drain on the lower branches of a plum tree, fronting the farmhouse near Stockton now occupied by Mr. Callendar. During this long period, seventy-three years, this bottle, with the exception of last year, has been annually tenanted in the breeding-season from generation to generation, by these little gay-plumaged visitors; and as they generally lay each year about fourteen eggs, it may fairly be computed that this wonderful, inexhaustible bottle, has been the birth-place of above a thousand Blue-caps. About thirty years ago, the old plum tree, upon whose boughs the bottle was first placed, having fallen into a state of decay, the bottle was placed upon the branches of an adjoining plum tree, to which it is now fastened by iron hoops. The little creatures, however, did not desert their favourite tenement by this change. Last year they made their appearance, as usual, at the bottle, but the inmates of the farmhouse having neglected to draw 
the previous year's nest out of it, the birds not having room to build, were necessitated to seek other quarters. This year, however, they have built again in their old residence, where they are at present daily employed in attending to the wants of a numerous progeny.'

The nest is also often placed under the eaves of houses, the tiles of the roof, or any suitable part of an out-of-doors building; if in a tree, the outer passage leading into an inner apartment is hollowed out by the bird itself in a truly marvellous manner, as smoothly as if wrought by the hand of man: one has been known to build in the end of a disused leaden pipe.

Mr. M. Saul has narrated in the 'Zoologist,' the following most singular instance of something akin to reasoning in a case of the kind, if indeed the motive was such as he has imagined:- 'Two birds made their appearance; one entered the hole, and appeared to be pecking away at the wood inside, for as it managed to separate piece after piece, it brought them to the other bird, which remained at the entrance; and this last flew away with each piece, and carrying it to a distance from the tree, dropped it on the middle of the road, as if to avoid the detection which was almost sure to follow, if the chips had been carelessly dropped at the foot of a tree in a frequented thoroughfare.'

The same nest is frequently repaired from year to year: the Revs. Andrew and Henry Matthews have known one resorted to for twelve successive years. It is said, however, that if two broods are brought up in the year two different situations are chosen for the purpose: sometimes two pairs will quarrel for the same situation.

The eggs are generally seven or eight in number, but have been known as few as six, and as many as sixteen, and some have said even eighteen or twenty; the usual number being from eight to twelve. They are of a delicate pink white, more or less spotted, and most so at the larger end, with clear rufous brown.

One variety is much marked over with washes, spots, specks, anå blots of yellowish brown.

Another is elegantly thus dotted over only.

A third is white, with very faint dots. 


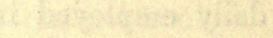

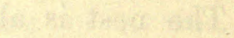




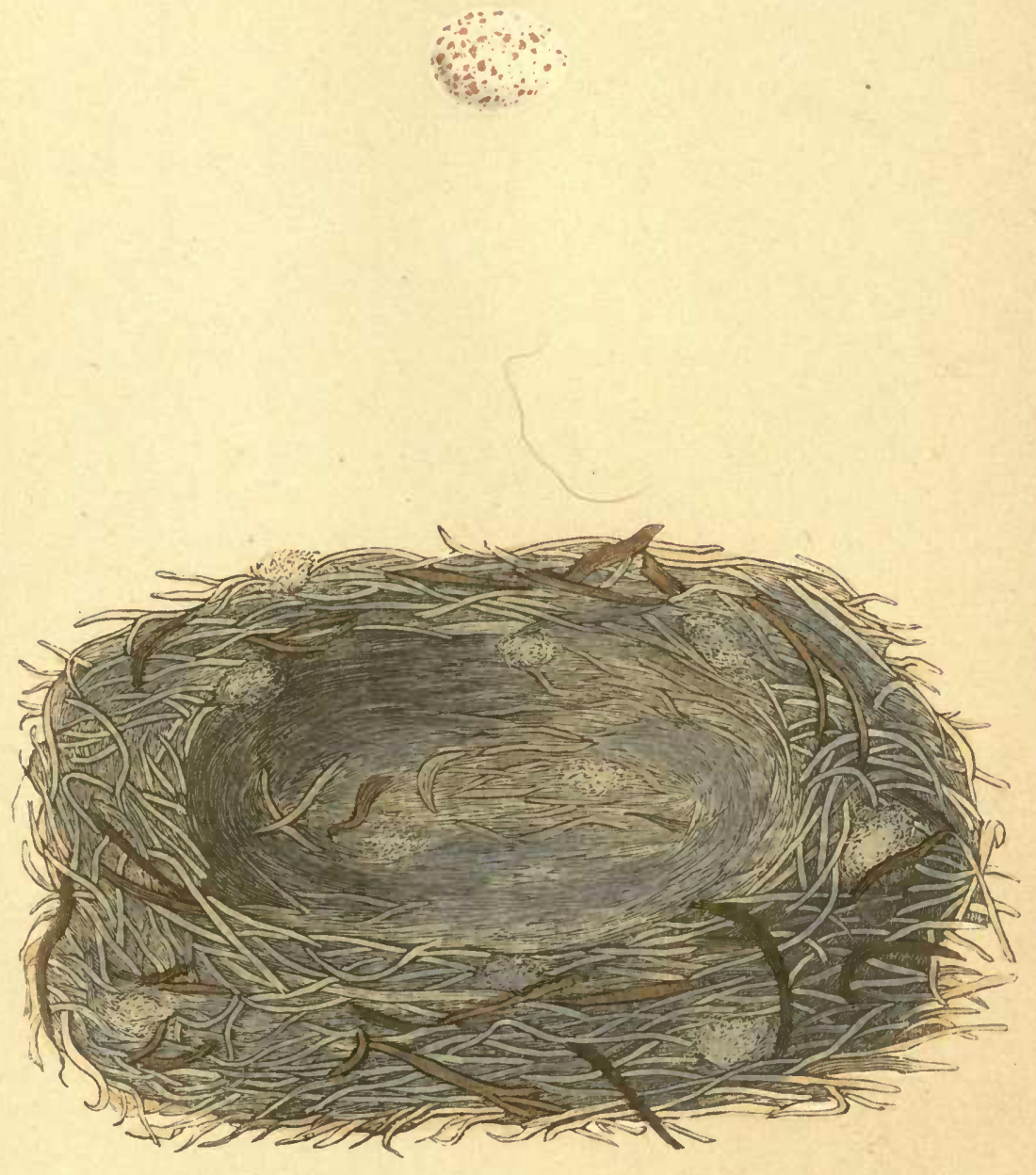


\section{MARSH TIT.}

MARSH TITMOUSE. BLACK-CAP. SMALLER OXEYE. WILLOW-BITER.

JOE BENT.

PLATE XXXIV.

$\begin{array}{ll}\text { Parus palustris, } & \text { Pennant. Montagd. } \\ \text { “ atricapillus, } & \text { Gmelin. }\end{array}$

Mr. Hewitson, on the authority of Montagu, says that considerable pains are taken by this species in hollowing and scooping out a suitable cavity for its nest, as it works, always downwards, in forming a passage to a larger apartment at the end. Montagu has observed it carrying away the chips to some distance in its bill.

The nest is described by the former as being somewhat more carefully made than that of others of the Titmice. It is formed of moss, wool, grass, willow catkins, horse-hair, and any other soft materials, and is placed in the hollow of a tree, snch as is afforded by the head of a pollarded willow, whose decapitation has been followed, as a necessary consequence, by decay.

I have been favoured by F. W. S. Webber, Esq., of St. Michaels, Penkivel, Cornwall, with a very pretty specimen of the nest of this bird, formed, apparently of rabbits' fur and fine shreds of bark, intermixed with a little wool.

The eggs are from five to seven or eight, nine, or even twelve in number, of a rotund form, white, spotted with light red, and most so at the thickest end, the other being more free from them: they are hatched in about thirteen days. The young do not fly until the end of July, and even nests and eggs have then been found, but it is possible that these may have been second broods.

In some the spots are larger than in others; in some they are very minute. 

, 

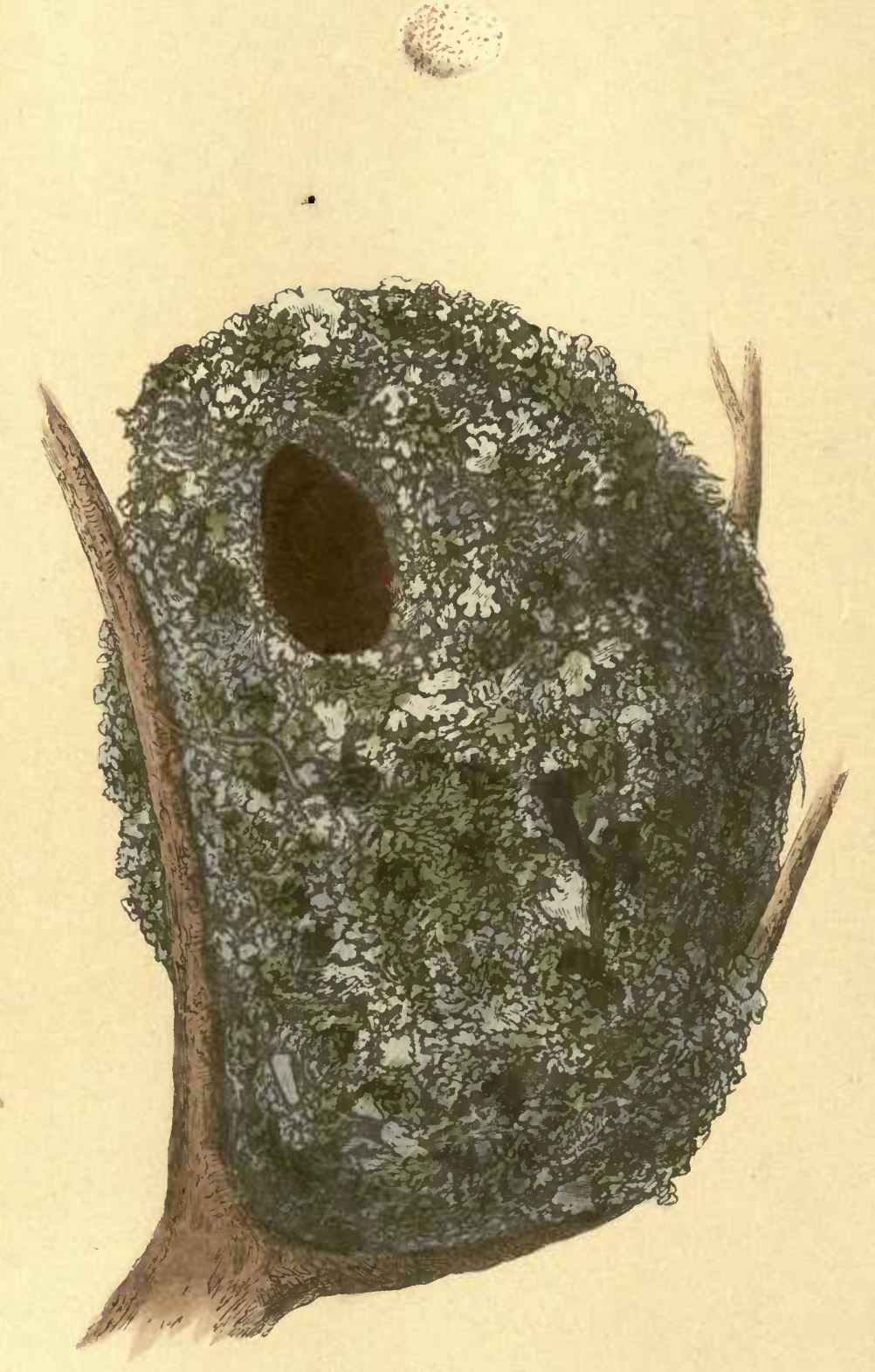


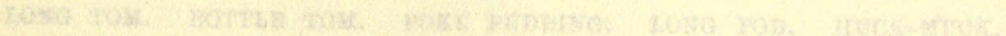

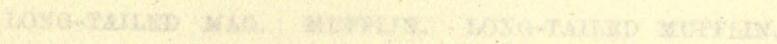

, 172

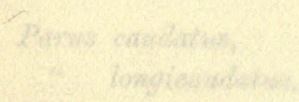

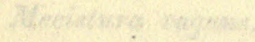

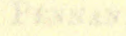

: $83 \sin \operatorname{son} 202$

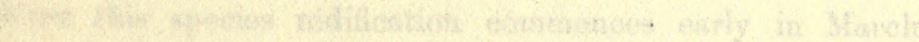

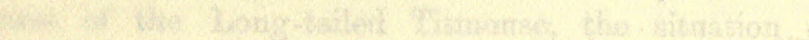

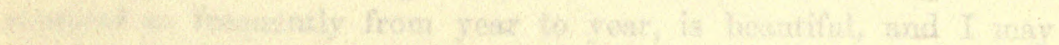

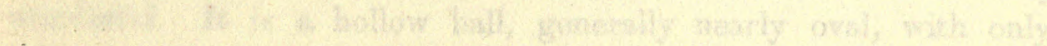

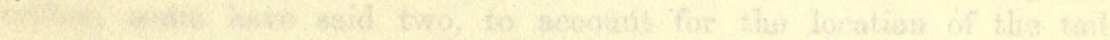

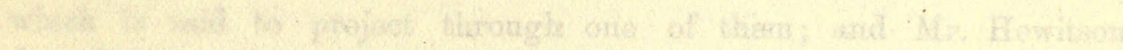

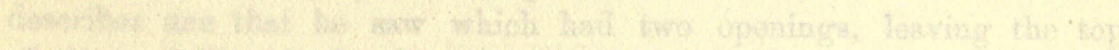

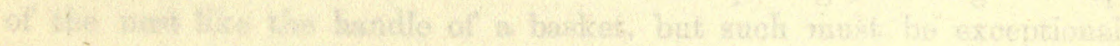
Q5:

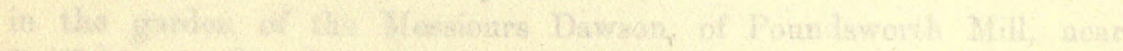

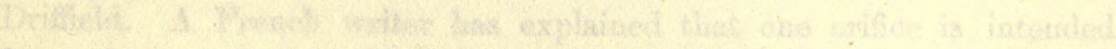

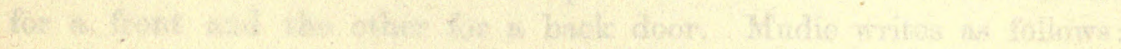

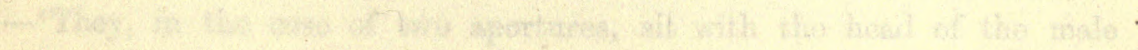

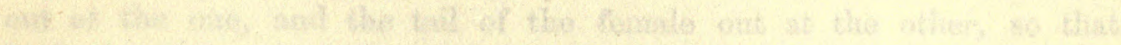

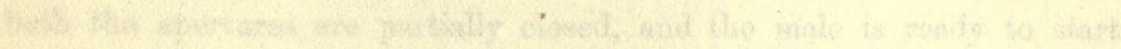

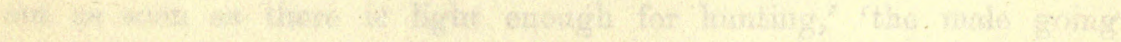

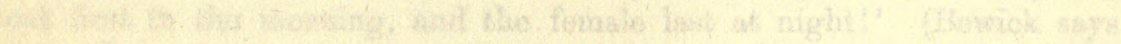

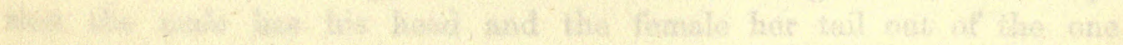

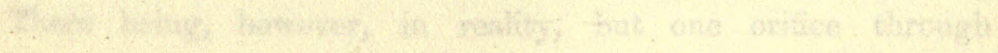
$\sin 2 \ln ^{2}$ 



\section{LONG-TAILED TIT.}

Y BENLOYN GNYFFONHIR, OF THE ANCIENT BRITISH.

LONG-TAILED TITMOUSE. MUM RUFFIN. BOTTLE TIT. LONG-TAILED PIE. LONG TOM. BOTTLE TOM. POKE PUDDING. LONG POD. HUCK-MUCK. LONG-TAILED MAG. MUFPLIN. LONG-TAILED MUFFLIN.

PLATE XXXV.

\section{Parus caudatus, " longicaudatus,} Mecistura vagans,
Pennant. Montagu. Brisson. LEACH.

With this species nidification commences early in March.

The nest of the Long-tailed Titmouse, the situation of which is repaired to frequently from year to year, is beautiful, and I may say wonderful. It is a hollow ball, generally nearly oval, with only one orifice; some have said two, to account for the location of the tail, which is said to project through one of them; and Mr. Hewitson describes one that he saw which had two openings, leaving the top of the nest like the handle of a basket, but such must be exceptional or accidental cases. In the year 1852, a similar instanced occurred in the garden of the Messieurs Dawson, of Poundsworth Mill, near Driffield. A French writer has explained that one orifice is intended for a front and the other for a back door. Mudie writes as follows: - They, in the case of two apertures, sit with the head of the male out at the one, and the tail of the female out at the other, so that both the apertures are partially closed, and the male is ready to start out as soon as there is light enough for hunting,' 'the male going out first in the morning, and the female last at night!' (Bewick says that the male has his head and the female her tail out of the one hole.) There being, however, in reality, but one orifice through vor. I. 
which they 'have their exits and their entrances,' will perhaps be a sufficient answer to both these theories. How the birds manage is another question, but certain it is that it is so. The nest is so admirably adapted by the lichens or moss it is elegantly covered with to the appearance of the tree it is built on, as to make it oftentimes very difficult to be detected.

It is generally placed between the branches of a tree, unlike those of the other Titmice, and frequently not far from the ground, or firmly fixed in a bush; is composed of moss, small fragments of bark and wool, compacted with gossamer-like fibres, and the cocoons of spiders' eggs, and the chrysalides of moths, and plentifully lined with feathers, so much so, as in some parts of the country to have acquired for it the 'sobriquet' of 'feather-poke;' one, on their being counted, was found to contain two thousand three hundred and seventy-nine. It is, as may be supposed, waterproof and very warm.

It is from five to seven inches long, by three or four wide, and the aperture about an inch and a half in diameter, and the same distance from the upper end. The elasticity of the materials of the nest tend to keep it rather closed. One has been seen in which a feather of the lining asted as a valve or door, but I think that this was probably accidental. The fabrication of the nest occupies from a fortnight to three weeks; and the credit of the handiwork belongs to both male and female; she not being, as has been asserted, the sole architect. They both, as it were, knead it during its formation with their breasts and the shoulders of their wings, aided by every variety of posture of the body.

The eggs are from ten to twelve in number, and occasionally, but very rarely, as many as sixteen. In reference to these cases, Mr. $\mathrm{H}$. Horsfall, of Calverley House, near Bradford, Yorkshire, writes as follows in the 'Zoologist,' p. 2567:- 'I suspect where the greater number is found, there will be more than one pair of birds attached to the same nest. I have known several instances where a considerable number of birds have had one nest in common: in one instance there were nine.' They are sometimes entirely white, or with the spots almost obsolete, but generally spotted a little with pale red. They are, as may be imagined, very small, being not much bigger than a large pea.

One variety is white, with a most elegant band of faint pink, with spots on it of a deeper tint around the base.

Another, also white, is covered all around the base with numerous small dots of yellowish and orange brown.

A third is white, with a few dots all over it of pale orango brown. 


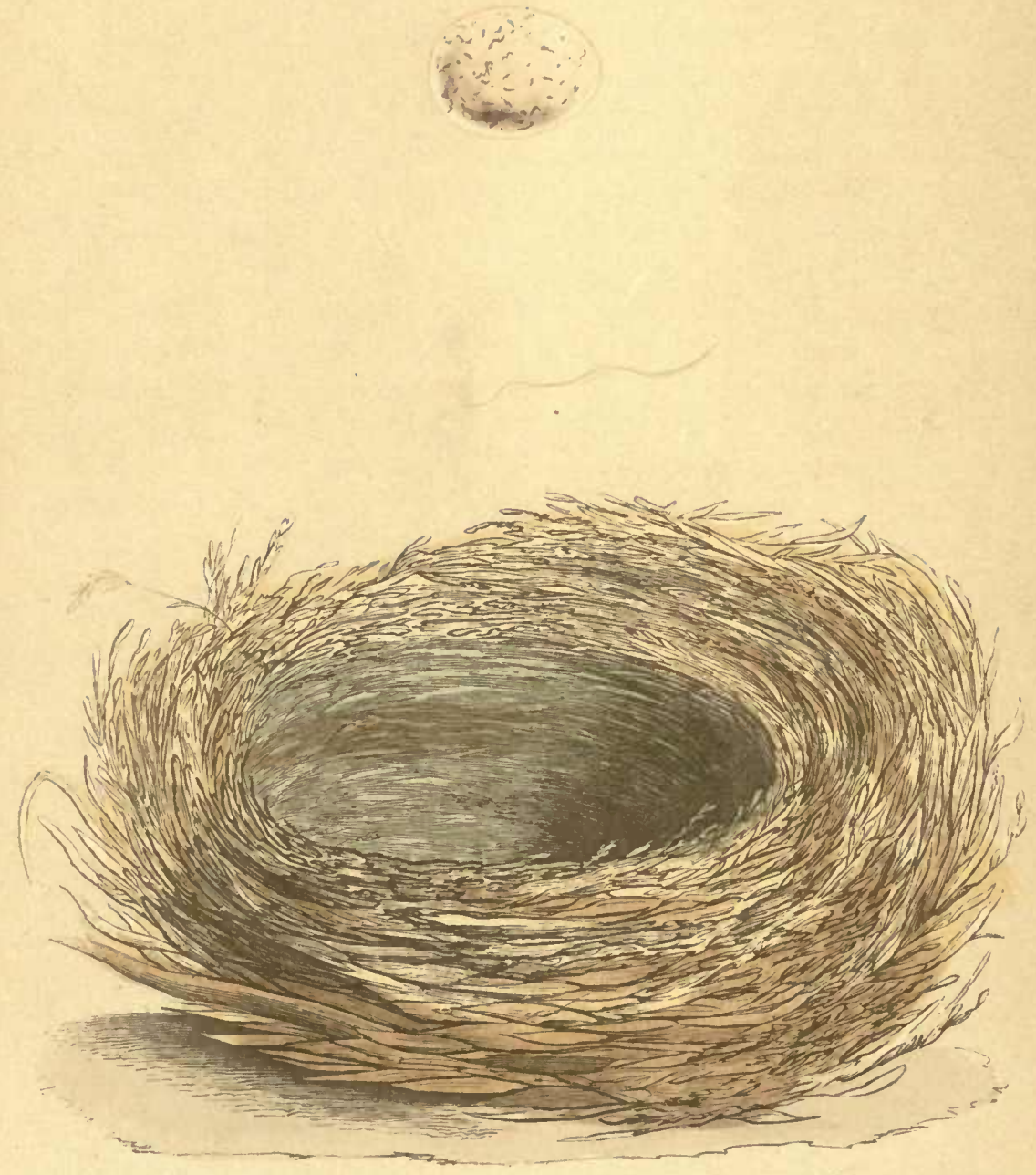


\section{BEARDEI) -TIT.}

Y BARFOG, OF THE ANCIEN'T BRITISH.

BEARDED TITMOUSE. LEAST BUTCHER BIRD. BEARDED PINNOCK. PINNOCK. REED PHEASANT.

PLATE XXXVI.

$\begin{array}{cl}\text { Parus barbatus, } & \text { Brisson. } \\ \text { " biarmicus, } & \text { LinN\&us. GMELIN. } \\ \text { Calamophilus biarmicus, } & \text { JeNYNs. GouLd. }\end{array}$

Nidification commences towards the end of April; one nest, however, was found in 1846, that spring having been very mild, which must have been built the latter end of March.

The nest is placed among tufts of grass on the ground, and is formed of dry stalks and blossoms of grass, reeds, and sedge, the finer ones on the inside, and the coarser on the outside. The figure is from a drawing by W. R. Fisher, Esq., of Yarmouth.

The eggs, which are from four to six, rarely seven in number, are of a white or faint pink colour, irregularly speckled, spotted, and streaked with reddish brown, with a tinge of purple.

One variety is white, with a very few spots of dull greenish brown. Another is also white with several small spots of dull greenish brown, and many short straight lines of the same, some of them joined together in an angular form. 



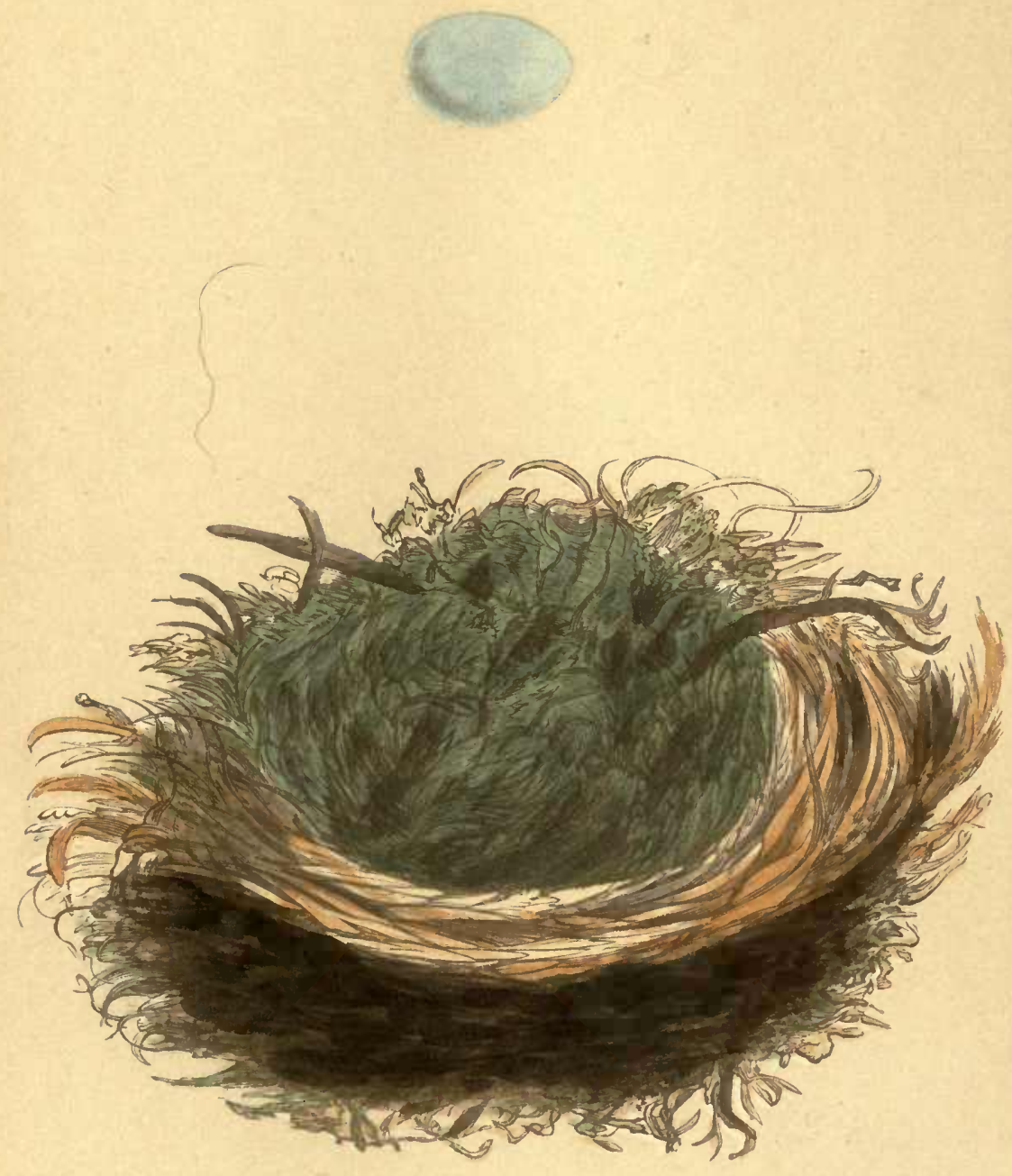




\title{
PIED FLYCATCHER.
}

\author{
COLDFINCH. EPICUREAN WARBLER.
}

PLATE XXXVII.
Muscicapa luctuosa,
" atricapilla,
" muscipeta,
Rubetra anglicana,

Temminck. Selby.

Grielin.

Bechstein.

Brisson.

Nidification takes place in May, and the young are hatched the beginning of June.

The nest, which is composed of moss, grass, straws, chips of bark, leaves, and hair, is built sometimes high up in trees, but often only a few feet from the ground, in a hole of a tree, or of a wall, or bridge, as also occasionally, on a branch or stump of a tree; if in a hole, and it be too large, the bird is said to narrow the entrance with mud. This species seems to have a predilection for the neighbourhood of water, probably on account of the greater number of insects to be there met with. The same situation appears to be resorted to in successive years. The engraving of the nest is from a specimen in the possession of Mr. Alfred Roberts, of Scarborough, obligingly permitted by him to be copied for the use of this work.

The eggs, from four or five to seven or eight in number, are small, oval, and bluish green, or sometimes nearly white; but they vary considerably in size and shape. Those observed in one nest by Mr. 'T. C. Heysham, of Carlisle, were disposed as follows:- 'One lay at the bottom, and the remainder were all regularly placed perpendicularly round the side of the nest, with the smaller ends 
resting upon it, the effect of which was exceedingly beautiful.' The young are hatched in about a fortnight: both birds by turns sit on the eggs.

One variety is grey, with a very faint tinge of the blue characteristic of them geneaally. 


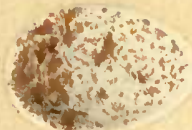

Qxis

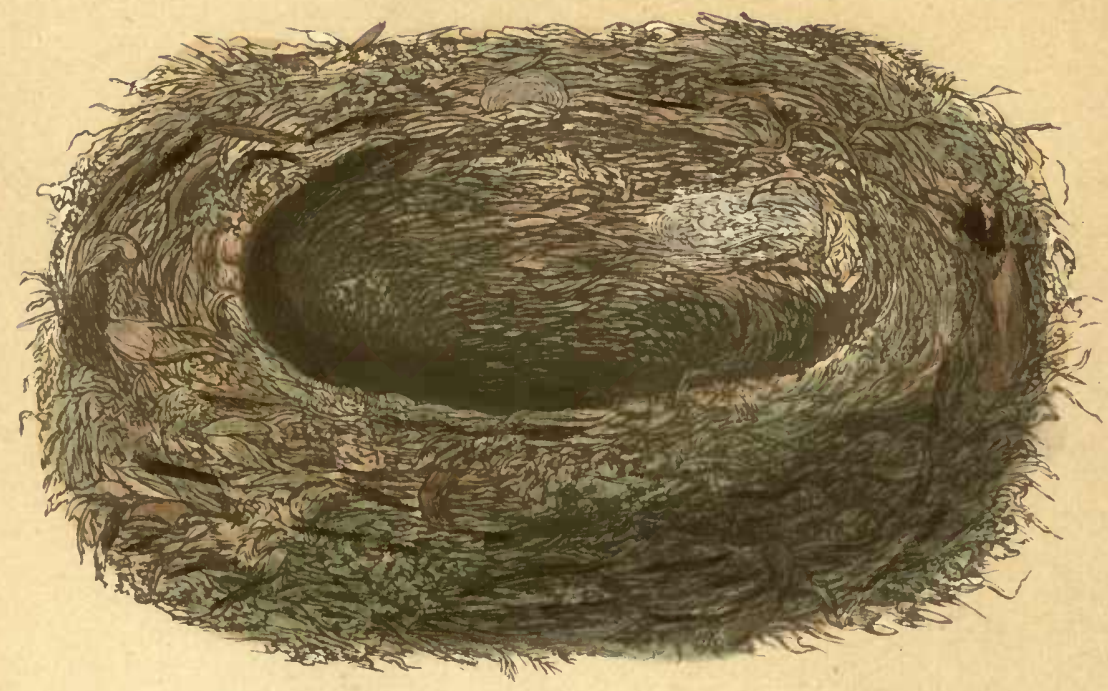




\section{SPOTTED FLYCATCHER.}

Y GWYBEDOG, OF THE ANCIENT BRITISH.

BEAM BIRD. RAFTER. COB-WEB BIRD. BEE BIRD. CHERRT CHOPPER. POST BIRD. CHERRY SUCKER. CHANCHIDER.

PLATE XXXVIII.

Muscicapa grisola,

Montagu. Pennant.

Nidification commences immediately after the arrival of the birds; they almost seem to have paired before their migration, or if not, at all events they do so at once when here.

The nest, which is built at the beginning of June, is composed of various materials, such as small twigs, catkins, and moss, lined with feathers, hair, down, and cobwebs. The same situation is resorted to year after year, and scarce any attempt is made at concealment. A pair which built in the trellis-work close to the drawing-room window of a house I once resided in, not being disturbed, returned there three successive summers, and I hope that they or their descendants do so still. Another pair have now for two seasons built in the same way, in the trellis-work over the drawing-room window of Nafferton Vicarage, in which this account of it is written. A favourite resort is such a place, or a tree trained against a wall, on account of the support afforded by it.

Another couple placed theirs in a tree immediately over an entrance door, which, whenever it was opened, caused them to fly off; another pair on the angle of a lamp-post in Leeds; and another on the ornamental crown of one in London. Another pair placed theirs on the end of a garden rake; another in a cage hung up in a tree, 
the door having been left open; and another in a stove, which seemed to be made 'too hot to hold them' when the thermometer in the hothouse rose above $72^{\circ}$, for the bird used then to quit the eggs, and only returned to them again when it fell below that point; disliking, it would seem, the 'Patent incubator.' Trees are also built in, ledges of rocks, holes in walls, the exposed roots of trees over a bank, the side of a faggot stack, or a beam in an out-building, whence perhaps another of its provincial names-the 'Beam Bird.' One pair made their nest on the hinge of an out-house door, in a village where people were continually passing and repassing.

Two broods are not uncommonly reared in a year, the first being hatched in June; but the second may be only the consequence of the first one having been destroyed.

The eggs, four or five in number, are greyish or greenish white, spotted with pale orange-coloured brown; in some the broad end is blotted with grey red. After the young have quitted the nest they are very sedulously attended by their parents. 
. 



\section{ROLLER.}

Y RHOLYDD, OF THE ANCIENT BRITISH.

GARRULOUS ROLLER. GERMAN PARROT.

PLATE XXXIX.-FIG. I.

Coracias garrula, Pennant. Montagu.

Galgulus " BRIsson.

Garrulus argentoratensis, $\mathrm{R}_{\mathbf{A Y}}$.

THE nest, composed of small fibres, straws, feathers, and hair, is built in the hollows of trees, but also, where the trees are scarce, on the ground or in holes of banks. In the former case, the birch is said to be preferred-whence the German name of the 'Birch Jay.' The same situation is resorted to again and again, if the birds have not been disturbed.

The eggs, of a rotund form, are from four or five to six or seven in number, and of a shining white, like those of the Bee-eater and Kingfisher. The male and female sit on them by turns, and they are hatched in about three weeks, during which time the latter is so devoted to her task, that she will frequently allow herself to be capa tured on the nest. The young are fed with insects and caterpillars, and the parents exhibit a strong attachment towards them. 


\section{KINGFISHER.}

GLAS Y DORIAN, OF THE ANCIENT BRITISH.

KINGSFISHER. COMMON KINGFISHER. COMMON KINGSFISHER.

PLATE XXXIX.-FIG. II.

Alcedo ispida,

Ispida senegalensis,

Gracula atthis,
Linneus.

Brisson.

Gmelin. Latham.

The nest is placed two or three feet within a hole in a bank, that, for the most part, of a water-rat, which the bird enlarges and alters as need be. It is said also sometimes to hollow out one for itself. It slants downwards, the principles of drainage being sufficiently understood by instinct. The same situation is perseveringly resorted to from year to year. Much discussion has taken place on the question whether the Kingfisher forms an artificial nest or not, the eggs being often found 'on the cold ground,' and often on a layer of fish bones.

The young remain in the nest until fully fledged. For a short time they then, perched on some neighbouring branch, receive their food from their parents.

The eggs, six or seven in number, are transparent white, and rather rotund in form. 


\title{
BELTED KINGFISHER.
}

\author{
GREAT BELTED KINGFISHER.
}

PLATE XL.

Alcedo alcyon, Linneus. Wilson.

The nest, composed of a few feathers and a little grass, is placed in a hole in the steep bank of a river, the excavation of the bird itself by means of its bill and claws, to the depth of one or two feet. The same situation is tenaciously revisited from year to year.

The eggs are five in number, and the bird has been known to go on laying, some of them having been from time to time removed, to the number of eighteen. The female sits in April. There seems to be two broods, of which the first is hatched the end of May or the beginning of June.

The figure is from an egg sent by J. R. De Capel Wise, Esq., of Lincoln College, Oxford. 

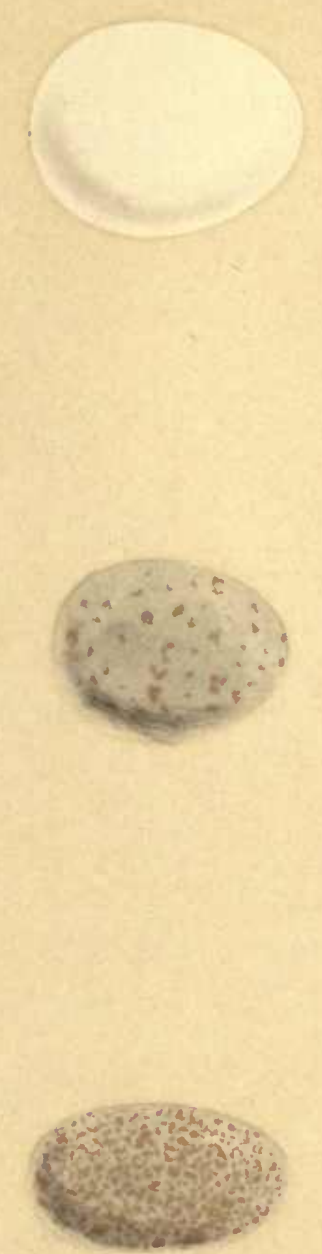


\section{BEE-EATER.}

YELLOW-THROATED BEE-EATER. COMMON BEE-EATER. GNAT-SNAPPER.

PLATE XLI.-FIG. I.

$\begin{array}{cl}\text { Merops apiaster, } & \text { Linneus. Pennant. } \\ \text { “ chrysocephalus, } & \text { Latham. } \\ \text { “ galilaus, } & \text { Hasselquist. }\end{array}$

THE nest is placed in holes in banks, which latter are thus, as is only to be expected in the case of a Bee-eater, completely 'honeycombed.' The bird scoops out a hole by means of its bill and feet, to the depth of from one to two yards, sufficiently large to admit its body, and its legs being short, a wide orifice is not required; this passage is widened out at the end into a receptacle for the nest, which is said to be composed of moss.

The eggs, which are hatched in May, are glossy white, of a globular form, and from five to six or seven in number. 


\section{HOOPOE.}

COMMON HOOPOE.

PLATE XLI.-FIGS. II, III.

Upupa epops,

Pennant. Montagu.

The nest, built in May, is placed in the hollow of a tree or a crevice of a wall, and is composed of dry stalks of grass, leaves, anc feathers.

The eggs vary from four to seven in number, and are of : uniform pale bluish grey, faintly speckled with brown.

The lower egg on the plate is from a drawing by William Richarc Fisher, Esq., of Yarmouth, from a specimen in Mr. Doubleday' collection. 


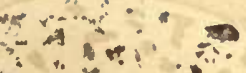

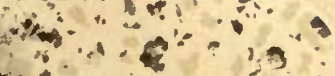
- 4 क 5 की 6.jo 


\section{CHOUGH.}

RED-LEGGED CROW. CORNISH CHOUGH.

CORNISH DAW. CORNWALL KAE. KILLIGREW. MARKET-JEW CROW.

CHAUK DAW. HERMIT CROW. RED-LEGGED JACKDAW.

CLIFF DAW. GESNER'S WOOD-CROW.

PLATE XLII.

Pyrrhocorax graculus, Corvus graculus, " docilis,

Fregilus graculus,
Fleming.

Pennant. Montagu.

GMelin.

Selby. Jenyns.

THE nest is made of sticks, and is lined with wool and hair. It is placed in the most inaccessible clefts and cavities of cliffs, or in old church or other towers, generally in the neighbourhood of the sea, but not always.

The eggs, four or five in number, are dull white, spotted with grey and brown, most at the thicker end.

The plate is taken from a drawing by William Richard Fisher, Esq., of Yarmouth, from an egg in the possession of Mr. Smith, of that place. 


\section{W121010170}

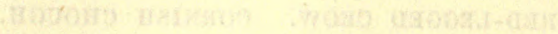

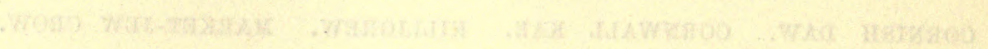

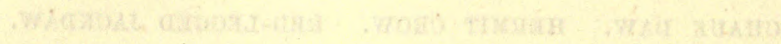

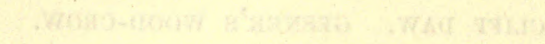

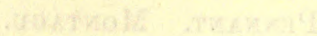

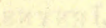

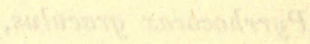

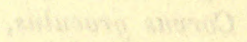

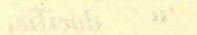

3ats

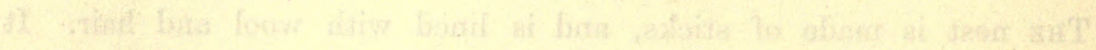

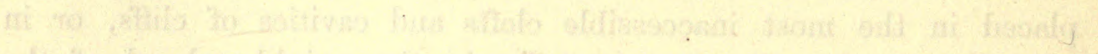

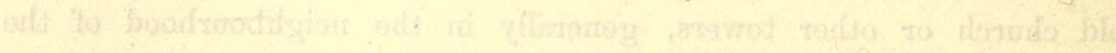

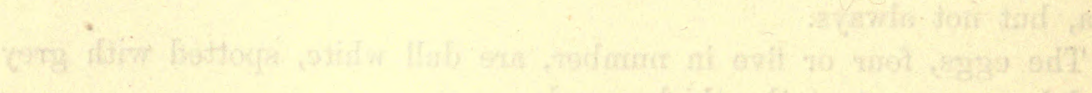

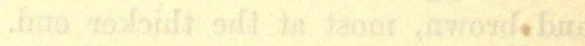

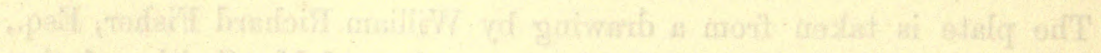

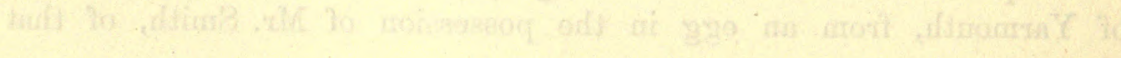



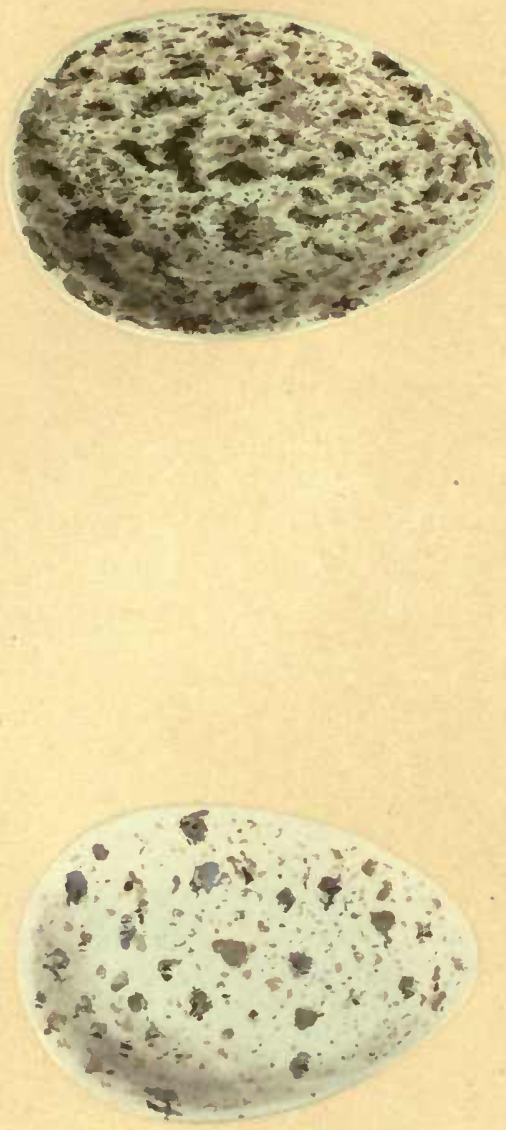


\section{RAVEN.}

CORBIE. CORBIE-CROW, GREAT CORBIE-CROW.

PLATE XLIII.

Corvus corax,

Pennant. Montagu.

Nidification commences early, even in the coldest climates: here sometimes so soon as January, and the eggs have been taken in the middle of February. Incubation lasts about twenty days: the male and female both sit, and the former feeds and attends upon the latter.

The nest, which is large, and composed of sticks, cemented together with mud, and lined with roots, wool, fir, and such materials, is placed in various situations-in the clefts of the branches of tall trees, church towers, caves, cliffs, and precipices. The mansoleum in the park of Castle Howard, the seat of Lord Carlisle, in Yorkshire, is still resorted to for that purpose.

The eggs are four, five, six, or seven in number, of a bluish green colour, blotted with stains of a darker shade, or brown: they vary much in shape.

One variety is pale grey, slightly dotted with a few distinct dots and marks.

A second is light green, with a few dashes and many small marks of a darker hue.

A third, pale greenish grey, marked thickly all over with small marks.

A fourth is dull pale olive green, with oblong marks and dots all over.

A fifth is pale greenish, striated and blotted with small blots all over.

A sixth is pale olivaceous green, marked in a similar way. vor. I. 
A seventh is dark dull olive brown, tinged with green darker and lighter all over.

An eighth, the same, with very few marks.

A ninth is dark greenish olive, with very many dots and irregular small blots.

A tenth is dark yellowish green, with a few large blots:

The young are generally fledged about the end of March, or beginning of April. 


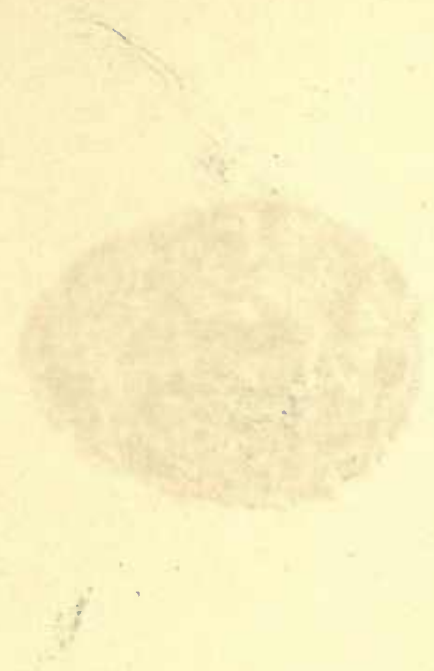



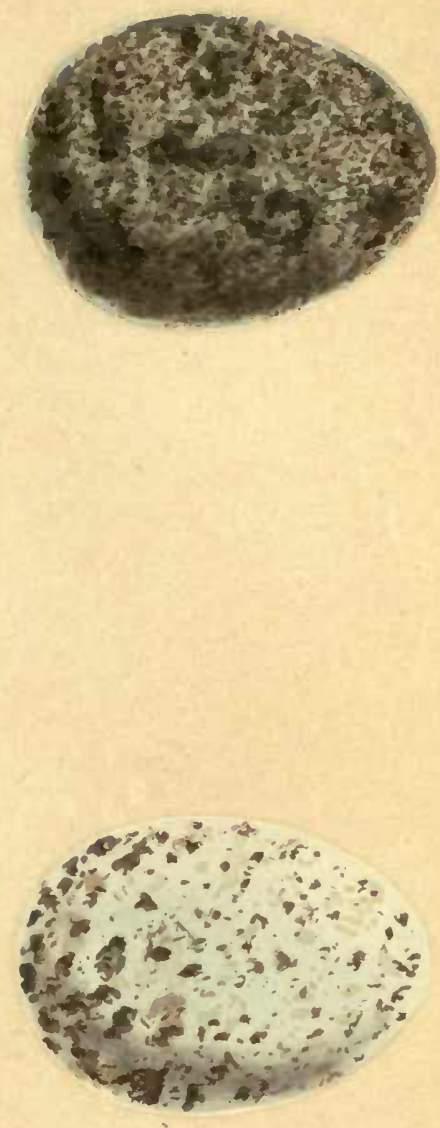


\section{CROW.}

CARRION CROW. GOR CROW. GORE CROW. BLACK NEB. FLESH CROW.

PLATE XLIV.

Corvus corone,

Pennant. Montagu.

Nidification begins the end of February, or beginning of March, both birds helping to make the nest.

The nest is built in rocks or in trees, generally high up, and is made of sticks, firmly cemented with clay, and lined with roots, and again with straw, wool, moss, fur, hair, or anything else that is soft: the latter the Crows pull for the purpose from the backs of animals. It is usually concealed as much as may be, for instance, among the topmost branches of a tall fir tree; but if not, is placed on some bough near to the trunk of the tree, or in the cleft formed by the main branches. A pair built on the ground in one of the Fern Islands, and their nest was made of pieces of turf laid one upon another, and lined with wool, all brought from the mainland, four or five miles distant. The Rev. W. Waldo Cooper has known a nest repaired the second year.

The eggs, four to six in number, are pale bluish green, spotted and speckled with grey and brown: some are pale blue undertinted with grey.

One variety is almost white and immaculate.

A second is very pale green, slightly mottled over.

A third, the same ground colour, but with a few larger marks.

A fourth is dull light yellowish brown, with a few large marks and some smaller ones, the base nearly covered.

A fifth is dull olive green, much dotted all over.

A sixth is green, moderately marbled over.

A seventh is grey, slightly streaked and dotted. 
James Dalton, Esq., of Worcester College, Oxford, has one of a bright blue without any spots; all the others in the nest having been of the usual colour. 



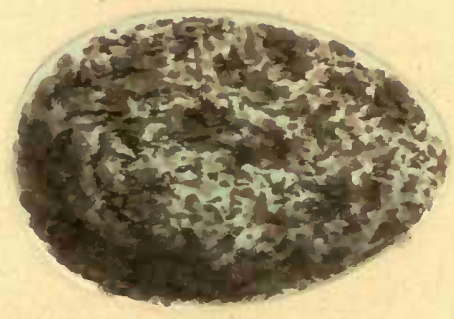




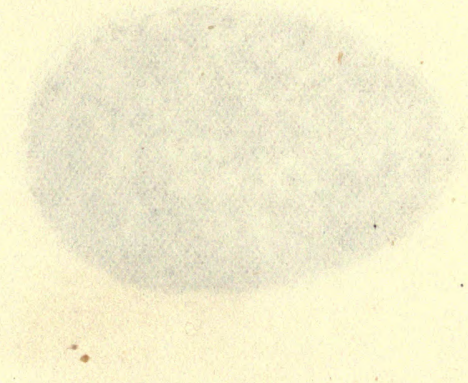




\title{
HOODED CROW.
}

\begin{abstract}
ROYSTON CROW. GREY CROW. GREY-BACKED CROW. SCARE-CROW. HOODY. DUN CROW. BUNTING CROW.
\end{abstract}

PLA'TE XLV.

$\begin{array}{cl}\text { Corvus cornix, } & \text { Linndeus. GMedin. } \\ \text { " cinerea, } & \text { Brisson. RaY. }\end{array}$

THE nest is placed in trees, or in the clefts and chasms of rocks and hill sides, and is composed of sticks, roots, stalks, or heather, and lined with wool and hair.

The eggs, from four to six in number, are of a green tint, mottled all over with greenish brown.

One variety is very pale yellowish green, slightly variegated with a few dull green blots, streaks, and dots.

Another is nearly all uniform dull dark green, here and there slightly marked with darker.

Another is of a bright yellowish green, moderately marked with dashes, streaks, and blots of greenish brown. .

A fourth is of a darker ground colour, much marked all over.

It will be seen by reference to Professor Thieneman's work, that that eminent oologist describes the eggs of the Crow and the Hooded Crow together, which is in accordance with the opinion entertained by some, as mentioned in my 'History of British Birds,' that both species are, so to speak, one. Certain it is that these two birds have not unfrequently been known to pair together in the wild state; but as the like has been known to be the case with other species, it is not of itself absolutely demonstrative of the fact. 


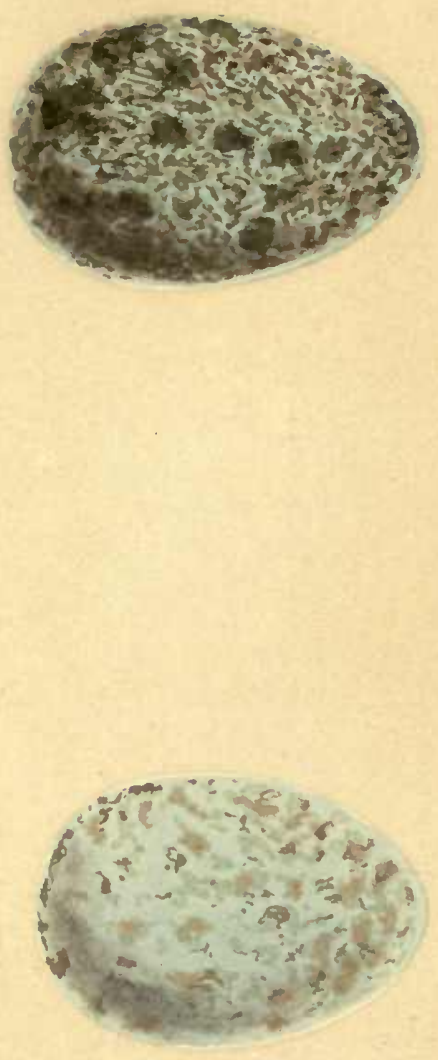


\title{
ROOK.
}

PLATE XIVI.

\author{
Corvus frugilegus, \\ Linnfus. Gmeitiv. \\ Cornix frugilega, \\ Brisson. \\ " nigra firugilega, \\ Ray.' WinLughir.
}

EARLY in March the nests of the previous year are begun to be repaired, and some new ones are necessarily built by the young of that date. The male diligently feeds the female, and occasionally takes her place on the eggrs. The young are fledged by the end of May, or the beginning of June; and second broods are sometimes produced as late as November; but possibly they should be considered rather as early than late ones.

The nest is composed of large sticks, cemented with clay, mixed with tufts of grass, and is lined with roots.

The eggs, four or five in number, are of a pale green ground colour, blotted over with darker and lighter patches of yellowish and greenish brown: they vary much.

One variety is nearly white, elegantly striated and dotted with brown.

A second is of a grey ground colour, marbled all over with a slightly darker shade of the same.

A third is of an olive brown tint, with extended waves, blots, and dots of darker.

A fourth is pale greenish, slightly mottled all over, principally at the base.

A fifth is dark greenish brown, much mottled with a darker shade of the same. 



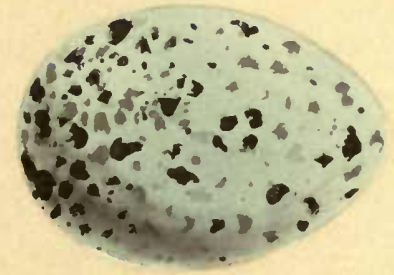




\section{JACKDAW.}

DAW. KAE.

PLA'T'E XLVII.

Corvus monedula,

Linneus. Gmeins.

$J_{\text {ACKDAWs }}$ build in cliffs, church and other towers, rabbit burrows, the roofs of buildings, the holes of ruins, hollow trees, the sides of challk-pits, and even in chimneys, despite of the smoke, as if conscious that it could not blacken their plumage: they inhabited the ruins of Stonehenge in Pennant's time, and may do so yet.

The nest, is built of sticks, and is lined with wool, hair, grass, and other soft substances. Very large quantities of sticks are collected for the purpose, so as even to block up chimneys, and the spiral stairs of church towers; the immense masses heaped together in the western towers of York Minster formed a most unfortunate kind of firewood for the last tremendous conflagration that occurred there. They used to build in the tower of my own church, but when it was restored, wire net-work was placed in the belfry window, so as effectually to stop them there; one persevering pair, however, would not be even thus foiled, but actually brought a mass of sticks through one of the loopholes in the tower; and though their being naturally conveyed crosswise in their bills created an almost insuperable difficulty, quantities falling down outside, yet it was marvellous to see the numbers which 'by hook or by crook' they got in. The spiral nature of the staircase increased their difficulty, so much larger a quantity of materials being required to make a foundation.

One instance is related by Alexander Hepburn, Esq., in the 'Zoologist,' of the Jackdaw having built on the branches of trees; and Mr. G. B. voL. I. 
Clarke, of Woburn, Bedfordshire, tells me that 'some of the Jackdaws in Woburn Park, instead of building their nests as they had hitherto done in the holes of trees, have taken to placing them (1850) in some of the branches of the Scotch firs, the foundation being composed of small twigs, and the remainder of coarse grass or sedge, lined with fine dry grass.'

The eggs, from four to six in number, are pale bluish white, spotted with grey and brown.

James Dalton, Esq., of Worcester College, Oxford, has one of a pure white; all the others in the nest having been of the usual colour.

Another variety is pale greenish blue, mottled all over with a fow large and many smaller spots and marks of dark brown or black, light yellowish brown, and other colours of different intermediate shades between these two.

A third is marked much in the same way, but without the largest of the markings.

A fourth is marked similarly, with only the smallest of the spots and marks, and the ground colour is much lighter.

A fifth is nearly white, elegantly marked with a very few brownish and blackish rather large irregular-shaped dots.

These eggs vary also in size and shape.

The young are hatched in the end of May. 

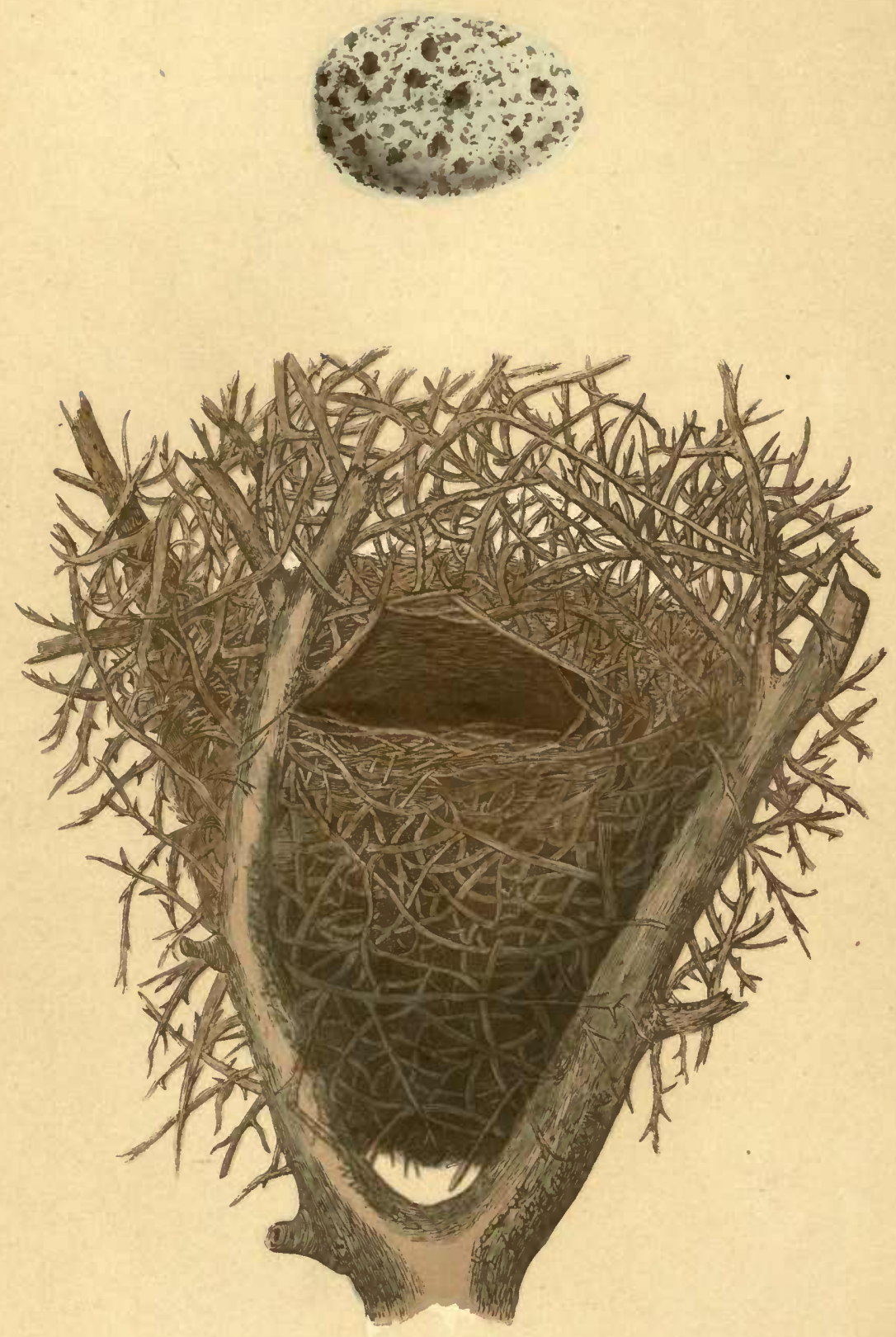


\title{
MAGPIE.
}

\author{
COMMON MAGPIE. PIANET. MADGE.
}

PLATE XLVIII.

Pica caudata, Corvus pica,
Freming. Selby. Gould.

Pennant. Montagu.

Nidification begins early in the spring.

The nest, which is resorted to from year to year, is placed in the top of a tall tree or hedge, or sometimes in a lower one, if otherwise suitably protectant. It is rather of an oblong shape, built of strong sticks and thorns, cemented together with mud, and lined with roots and grass; an aperture just sufficient to admit the bird is left on one side, and from this loop-hole any approaching danger is descried, in order to a timely retreat; the top is covered over.

I am informed by W. F. W. Bird, Esq., that the Magpie builds in Kensington Gardens.

The eggs are six or seven, rarely eight in number, pale bluish white, spotted all over with grey and greenish brown, more or less dark.

The Rev. I. Hall gives the following interesting account of a nest of these birds, which he met with in Scotland:- 'On the road between Huntly and Portsoy I observed two Magpies hopping round a gooseberry bush in a small garden, near a poor-looking house, in a peculiar manner, and flying out of and into the bush. I stepped aside to see what they were doing, and found from the poor man and his wife, that these Magpies for several successive years had built their nest and bronght up their young in this bush; and that the foxes, cats, etc. might not interrupt them, they had not only barricaded the nest, but had encircled the bush with briars and thorns in a formidable manner.' 


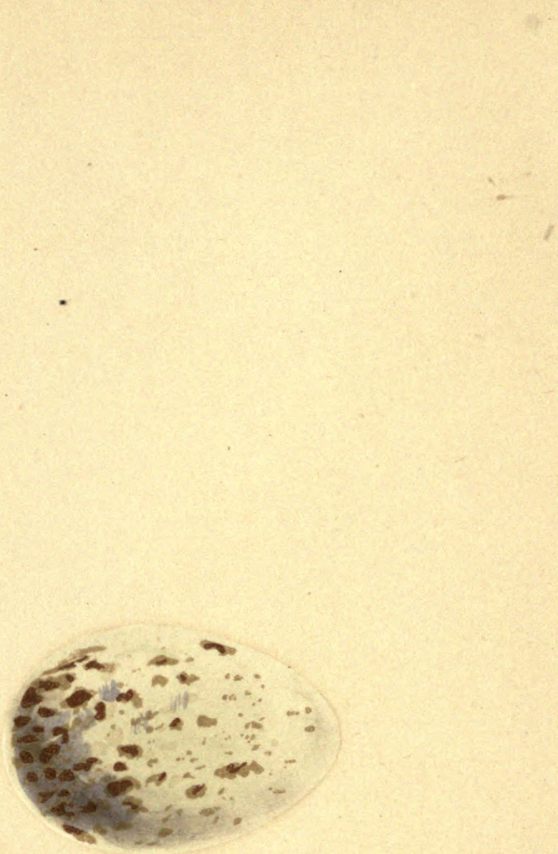


\title{
NUTCRACKER.
}

\author{
PLATE XLIX.
}

\begin{abstract}
Nucifraga caryocatactes, Caryocatactes nucifraga, Corvus caryocatactes,
\end{abstract}

Selby. Jenyns.

Fleming.

Pennant. Montagu.

The nest is placed in holes of trees, which they scoop out like Woodpeckers, till their purpose is gained.

The eggs are five or six in number, of a yellowish grey colour, spotted with lighter and darker shades of brown.

The figure of the egg is from one of two specimens sent by the Rev. H. B. Tristram, of Castle Eden, Durham. 

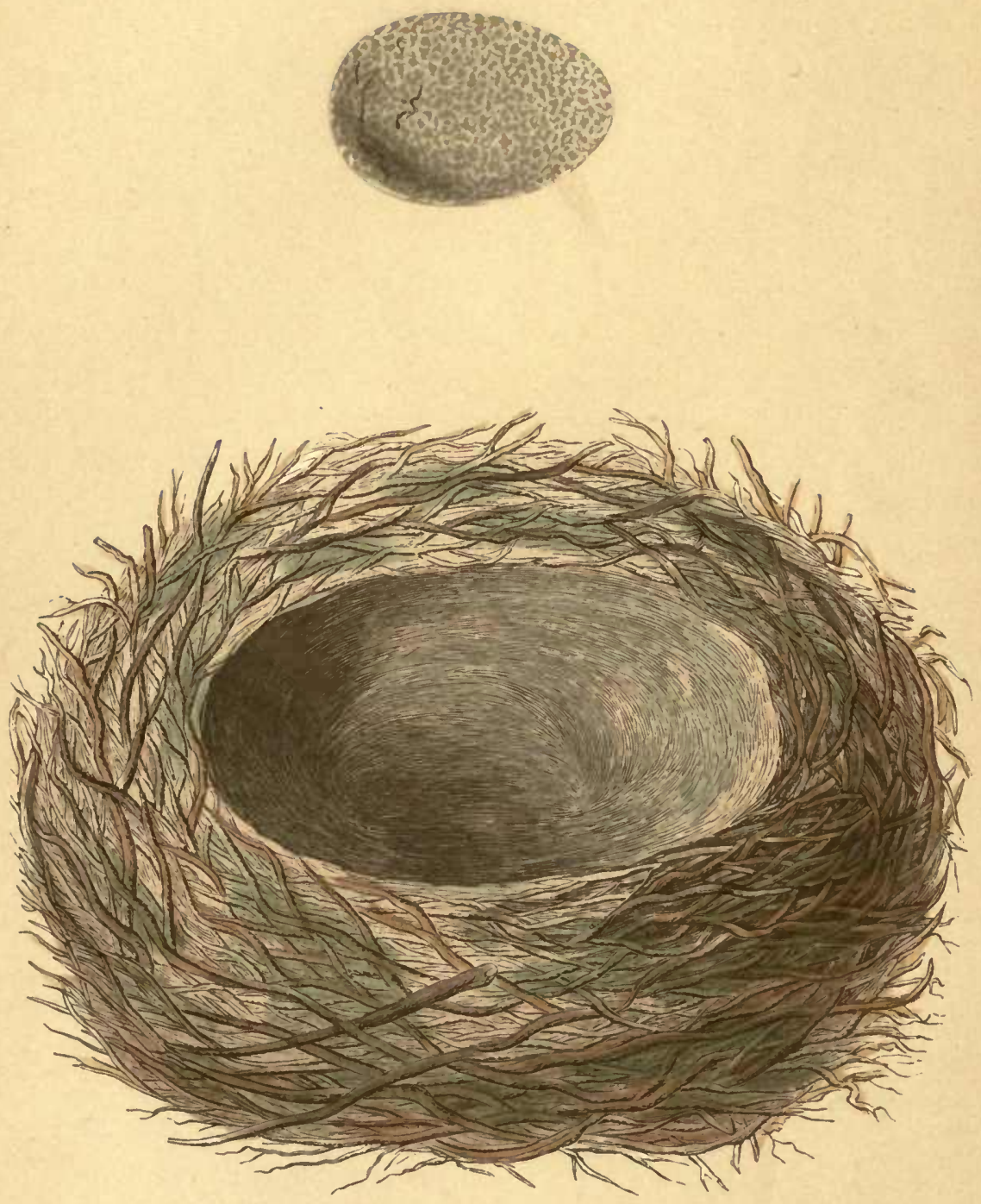


\section{JAY.}

PIATE L.

Garrulus glandarius,
Corvus glandarius,
Fleming. Selbi.

Pengant. Montagu.

THE nest is placed in a tall bush or hedge, generally at a not greater elevation than about twenty or thirty feet from the ground, and sometimes less. It is of an open shape, formed of sticks and twigs, and well lined with small roots, grasses, and horse-hair. Some are much more cleverly constructed than others.

The eggs, five or six in number, are greenish or yellowish white, freckled all over with two shades of light brown.

They vary occasionally both in size and in degree of polish, as well as in the ground colour.

Professor Thieneman figures six, which vary as follows:-

One is of a light yellowish olive brown colour, mottled all over with somewhat darker markings.

A second has a yellowish green tinge in its ground colour, which is mottled similarly to the last named.

A third is of a more uniform general tone, the ground colour being greenish and somewhat darker, and the markings less visible upon it.

A fourth is of a pale ground colour, yellowish white, much marked at the lower end with dark yellowish brown, and slightly mottled and speckled over the remainder of the surface with lighter marks of the same.

A fifth is still paler, without the dark marks at the base, but mottled all over with freckles of light brown.

A sixth is nearly white, scarcely marked at all with minute specks of pale yellowish brown. 




\title{
WAXWING.
}

\author{
BOHEMIAN WAXWING. BOHEMIAN CHATTERER. SILKTAIL. \\ EUROPEAN CHATTERER. WAXEN CHATTERER.
}

PLATE LI._FIG. I.

$\begin{array}{ll}\text { Bombycivora garrula, } & \text { Temminck. } \\ \text { Bombycilla garrula, } & \text { Fleming. Buonaparte. } \\ \text { “ Bohemica, } & \text { Brisson. } \\ \text { Ampelis garrulus, } & \text { Linnmus. GMelis. }\end{array}$

These birds are believed to breed within the limits of the Arctic circle-in holes among rocks, or in deep forests.

Professor Thieneman figures -two of the eggs, from which the plate is taken.

One is of a pale green colour, slightly dotted all over with small brown specks and dots.

The other is of a similar ground colour, but the spots, which are of a rather dark greenish brown colour, are somewhat more numerous, and a good deal collected together at the thicker end of the egg. 


\section{NUTHATCH.}

DELOR Y CNAW, OF THE ANCIENT BRITISH.

NUTJOBBER. WOODCRACKER.

PLATE LI.-FIG. II.

Sitta Europexa,

Pennant. Montagu.

THESE birds pair in March, and at once commence their nest, which is placed in some hole in a tree, frequently one previously made use of by a Woodpecker, at a height of from twenty to sixty feet from the ground. If the entrance be too large, they narrow it with clay, until it is of the right width. It is lined with dry leaves, the scales of fir cones, moss, bits of bark and wood, and sometimes a little grass.

The eggs, from five to seven or eight or nine in number, and of an oval form, are greyish white, spotted and sometimes much blotted with chesnut brown.

Incubation lasts about thirteen or fourteen days, and the female, while sitting, makes a hissing noise at any intruder. The young are fed principally with small caterpillars. 



\section{WRYNECK.}

GWAS Y GOG, OF THE ANCIENT BRITISH.

CUCKOO'S MATE. CUCKOO'S MAID. CUCKOO'S MESSENGER. RINDING-BIRD. SNAKE-BIRD. TONGUE-BIRD. LONG-TONGUE. EMMET-HUNTER.

PLATE LII.-FIG. I.

Yunx torquilla,

Linneus. Latham.

THE nest is placed in a hole of a tree, the mouldered wood of which seems to supply its chief or only lining, or rather layer. The apple tree is frequently chosen. It is made of small roots, and the old nest of a Woodpecker or some other bird would appear to be sometimes adapted, and in some slight degree fashioned with its bill, to its own use by the Wryneck. It domiciles at various heights from the ground, and various depths from the surface of the tree, often close to a road side, in view of every passer by.

The eggs, from six or seven to nine or ten in number, are pure white. The young are hatched in about fourteen days, and the female bird is so much attached to them, that she may easily be taken, not only while sitting on the eggs, but even after the young are hatched and fledged. The same spot is resorted to year after year. 


\section{CREEPER.}

Y GREPIANOG, OF THE ANCIENT BRITISH.

TREE CREEPER. COMMON CREEPER. FAMILIAR CREEPER. TREE CLIMBER.

PLATE LII.-FIG. II.

Certhia familiaris, Pennant. Montaqu.

Nidification commences in March, and a second brood is very frequently reared the same year, but not, it seems to be thought, in the same nest.

The nest is composed of grass, straws, fibres of roots, and twigs, bits of bark, spiders' webs, and the cocoons of chrysalides, lined with the latter and feathers. It is placed either in a hole or some crevice of the bark of a tree, the willow, as most affording such as it requires, being preferred, or even between two stems, and has been found in the interstice afforded by two palings: a hole previously tenanted by a Titmouse or other small bird is sometimes resorted to.

The eggs, eight or nine at the former brood, laid in April, and four or five at the second, are white, with a few red spots all over, or only at the thicker end. They are hatched in thirteen days, and both birds sit on them by turns. 



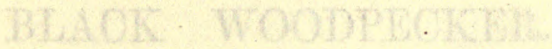

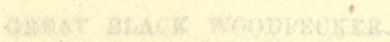





\section{BLACK WOODPECKER.}

GREAT BLACK WOODPECKER.

PLATE LIII.-FIG. 1.

Picus martius, Pennant. Montagu.

These birds commence building in the beginning of April, and the nest is placed in the hole of a tree, most frequently the fir, at a height, generally, of about fifty or sixty feet from the ground, or occasionally in a hollow of a wall. The entrance to it is narrow, but beyond this, it widens in a downward direction to the width of about nine inches. The chips and splinters made by the bird in excavating its nursery frequently betray the locality to the curious, some of them being of considerable size, even several inches long; so great is the power of the bill, acting almost like a bill-hook.

The eggs, from three, it is said, to five or six in number, are white, smooth, and shining. The male is reported to take his turn on the nest, and this labour of both lasts for seventeen or eighteen days. The young are fed with ants' eggs, and are so carefully guarded by their parents, that they will hardly quit the nest if it be approached. 


\section{GREEN WOODPECKER.}

ECLE. LARGE GREEN WOODPECKER. POPINJAY. WOODSPITE. RAIN-BIRD. RAIN-FOWL. WHITTLE. HIGH HOE. HEW-HOLE.

PICK-A-TREE. AWL-BIRD. YAPPINGAL. YAFFLE. YAFFER. NICK-A-PECKER.

PLATE LIII.-FIG. II.

Picus viridis,
Brachylophus viridis,
LinNaUs.

SwAINSON.

Preparations for building are commenced even so early as February, and the old nest is frequently resorted to and repaired. The nest, if decayed wood-dust may be called such, is placed at a height of fifteen or twenty feet from the ground, in a sound hole in a tree.

The eggs, four or five, to six or eight in number, are bluish white in colour. In the 'Zoologist,' page 2229, Alfred Newton, Esq. mentions his having met with five eggs of this bird in a nest at Elvedon, near Thetford, Norfolk, which were blotted and spotted with reddish brown and tawny yellow; and at page 2301, he speaks of having been informed of two other similar instances, one, or both of them, in the same neighbourhood.

The young are hatched in June. The parents are sedulously devoted to them. 



\section{GREAT SPOTTED WOODPECKER.}

WHITWALL. WITWALL. WOODWALL. WOODNACKER. WOODPIE. FRENCH PIE. PIED WOODPECKER. GREATER SPOTTED WOODPECKER. GREAT BLACK AND WHITE WOODPECKER. FRENCH WOODPECKER.

PLATE LIV.-FIG. I.

$\begin{array}{ll}\text { Picus major, } & \text { Pennant. Montagu. } \\ \text { " varius major, } & \text { RaY. }\end{array}$

AвоUт the end of March, or beginning of April, the nidification of these birds commences.

No nest is formed; the eggs are laid on the dust that lodges at the bottom of the hole, at a depth of six or seven inches, but sometimes as much as two feet from the orifice. A pine tree seems to be preferred, but the oak and others are also made available; a pre-existing hole being adapted to their wants, or, if there be none such, a new one is scooped out of the most unsound part of the tree. There is frequently a second hole, which facilitates the escape of the bird in case of danger.

The eggs are four or five in number, white and glossy, and are hatched after an incubation of fifteen or sixteen days.

The figure is from an egg in the possession of Mr. Smith, of Yarmouth, which was laid by the bird in his pocket, as he was taking it home soon after its capture. 


\section{LESSER SPOTTED WOODPECKER.}

LEAST SPOTTED WOODPECKER. LITTLE BLACK AND WHITE WOODPECKER.

BARRED WOODPECKER. HICKWALL.

LITTLE FRENCH WOODPECKER. PUMP-BORER. CRANK-BIRD.

PLATE LIV.-FIG. II.

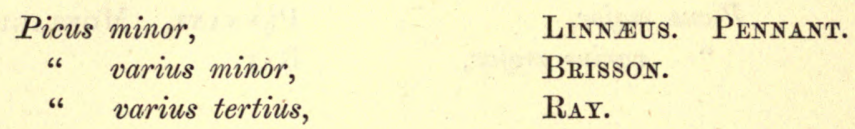

ThE nest, so to call it, is placed at the bottom of a hole in a tree, in some cases found ready made to its hand, and at others adapted by itself to its requirements. Sometimes more than one hole is either wholly or in part thus fashioned, though only one can be finally occupied.

The eggs, generally five in number, are white; they are hatched in fourteen days. 
. 



\title{
HAIRY WOODPECKER.
}

\author{
PLATE LV.-FIG. I.
}

Picus villosus,

Linnaus. Gmelin.

Nidification begins in May, when a branch already hollow is pitched upon, or a fresh opening is made. 'In the former case,' says Wilson, 'I have known his nest more than five feet distant from the mouth of the hole; and in the latter, he digs first horizontally, if in the body of the tree, six or eight inches, and then downwards, obtusely, for twice that distance; carrying up the chips with his bill, and scraping them out with his feet. They also not unfrequently choose the orchard for breeding in, and even an old stake of the fence, which they excavate for this purpose.'

The eggrs are white, five, or thereabouts, in number, and are laid in June. 


\title{
THREE-TOED WOODPECKER.
}

\author{
NORTHERN THREE-TOED WOODPECKER.
}

PLATE LV.-FIG. II.

$\begin{array}{ll}\text { Picus tridactylus, } & \text { LINNAUS. } \\ \text { Apterus tridactylus, } & \text { SWAINSON. } \\ \text { Picoides tridactylus, } & \text { LACEPEDE. }\end{array}$

A ноLе in a pine tree is the favourite receptacle for the eggs of the Three-toed Woodpecker; and these, four or five in number, are of a brilliant whiteness. 




\title{
YELLOW-BILLED CUCKOO.
}

\author{
AMERICAN YELLOW-BILLED CUCKOO. VIRGINIAN CUCKOO. \\ CAROLINA CUCKOO. COW-BIRD. RAIN-CROW.
}

PLATE LVI.

$\begin{array}{ll}\text { Cuculus Americanus, } & \text { LINNEUS. } \\ \text { Couyrus Americanus, } & \text { LINNAUS. JENYNS. } \\ \text { Cuculus cinerosus, } & \text { TEMMINCK. } \\ \text { " Carolinensis, } & \text { WILSON. } \\ \text { Erythrophrys Americanus, } & \text { SWAINSON. }\end{array}$

THe nest is commenced about the end of the first week in May. This species of Cuckoo does build a nest for itself, though of rude construction, and nearly flat. It is placed on the branch of a tree, and is made of small sticks and twigs, intermixed with weeds and blossoms; Meyer says that it is made of roots and wool.

The eggs, three, four, or five, generally four in number, are of a uniform greenish blue colour, and of a duly proportionate size.

This species is said by Audubon occasionally to lay its eggs in the nest of another bird.

I am indebted to J. R. Wise, Esq., of Lincoln College, Oxford, for the loan of the egg from which the figure is taken. 


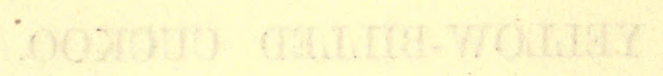

$3+2 x+x+2 x=$

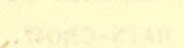

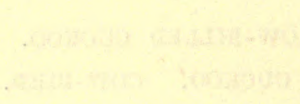







\section{CUCKOO.}

COG, OF THE ANCIENT BRITISH.

COMMON CUCKOO. GOWK.

PLATE LVII.

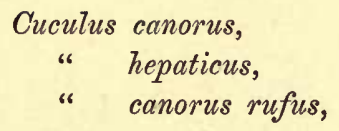

Linnzed. Montagt.

LATHAM.

Gmelin. Lutham.

THIs species deposits its parasitical eggs in the nest of some other small bird, for which they are not too large, being singularly small in proportion to its own size-just one quarter what they should be in proportion to those of small birds, than which they are themselves four times larger.

The eggs are not laid until the middle of May, and they require about a fortnight's incubation. They are of a dusky grey colour, mottled over with a darker shade. Montagu found one so late as the 26th. of June; and Mr. Jesse records that a young Cuckoo, which had only just left the nest of a Wagtail, was found in Hampton Court Park, on the 18th. of August, 1832. The young birds are not able to fly in less than five or six weeks.

J. R. Wise, Esq., of Lincoln College, Oxford, has obligingly forwarded me nineteen specimens of the eggs of the Cuckoo, from one of which the figure is taken. 



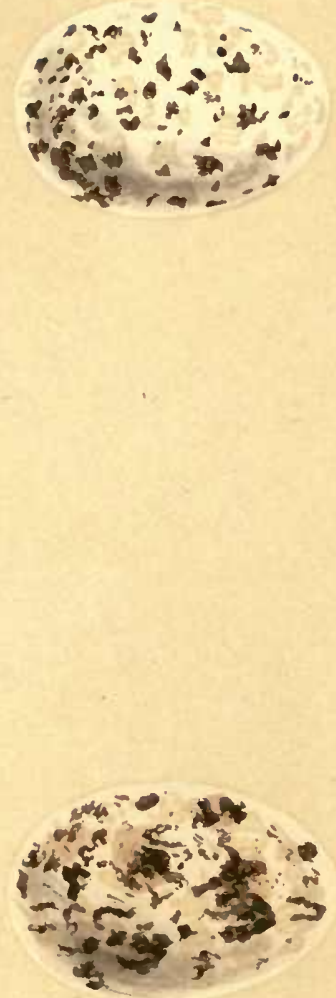


\section{NIGHTJAR.}

ADERYN Y DROELL, AND RHODWR, OF THE ANCIENT BRITISH.

GOATSUCKER. DOR-HAWK. NIGHT-HAWK. FERN-OWL. WHEEL-BIRD.

EUROPEAN GOATSUCKER. NOCTURNAL GOATSUCKER. CHURN-OWL.

JAR-OWL. PUCKERIDGE.

PLATE LVIII.

Caprimulgus Europoens,

" punctatus,

Nyctichelidon Europous,
Pennant. Montagu.

MeYer.

RenNie.

Is the middle or the end of May, nidification, so to speak where no nest is found, commences.

The nest, if a few chance leaves in a hollow of the ground are to bo called such, is found in the open rides and walks in woods, as also in their bordering neighbourhood, in moors and barren places, among heath, grass, or fern, from the latter of which one of its secondary names is derived. It is frequently placed at the foot of a tree or a bush.

The eggs are generally two in number, but three have been known in two instances: in one by Mr. Eddison, and in the other by the Rev. J. Pemberton Bartlett, namely, in the latter case, two young birds and an egg. They are very beautiful, and of nearly a perfect oval shape, the ground colour being white, which is most beautifully clouded and streaked with bluish grey and yellowish brown. The eggs are laid the beginning, and the young are hatched in the middle of July. 


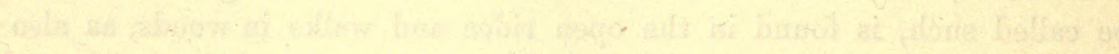

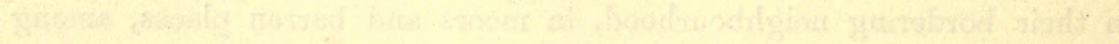

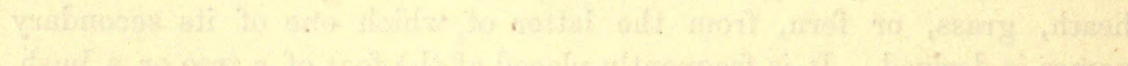

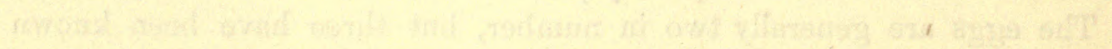

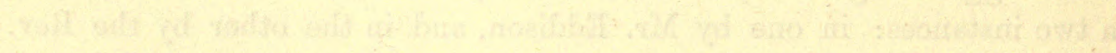

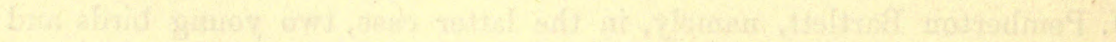

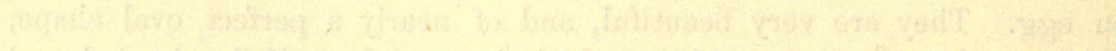

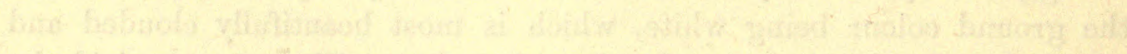

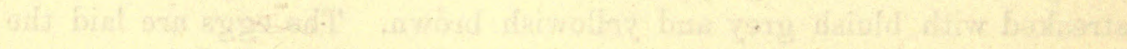
Wathe 




\section{SWIFT.}

MARTIN DU, OF THE ANCIENT BRITISH.

COMMON SWIFT. SWIFT SWALLOW. BLACK MARTIN. SCREECH. SCREECH MARTIN. SCREAMER. CRAN. SQUEALER.

PLATE LIX.

Hirundo apus, Cypselus murarius, "apus,
Micropus murarius,
Brachypus murarius,
Linneus. Pennant. Montagu. Selby. Gould.

JENYNS.

Meyer.

MeYer.

THE nest is generally placed in holes about steeples of churches, and the old walls of lofty towers, as also under the eaves of cottages and barns, crevices under window-sills, and even in hollow trees; under the arches of bridges, in the sides of cliffs, and of chalk-pits. It is roughly formed of straws, wool, grasses, hair, feathers, and such like materials, agglutinated together; picked up with great dexterity while the bird is on the wing, or purloined, so some say, from, or found in the nest of Sparrows, which they appropriate to themselves. It may be that no nest, or next to none, is formed, unless the remains of a Sparrow's nest are used. With the Martins, however, the case is exactly opposite: 'thou art the robber,' they might say or sing to the Sparrow.

The ordinary number of eggs is for the most part two, but sometimes three; and J. J. Briggs, Esq. has, in one instance, at Melbourne, in Derbyshire, known four. Speaking of the nest that contained them, he also relates 'a pair of Swifts has inhabited a particular hole in a cottage for more than twenty summers.' This is not a solitary instance of four eggs being found in one nest. They are white.

vOL. I. 


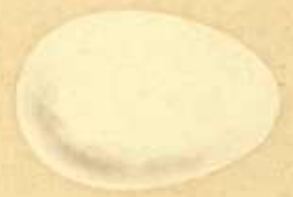

thes 


\title{
ALPINE SWIFT.
}

\author{
WHITE-BELLIED SWIFT.
}

PLATE LX.

Cypselus alpinus,

Selby. Jenyns.

THe Alpine Swift builds its nest among high rocks in mountainous districts, and in holes in the steeples of cathedrals and churches: the old situation is often again resorted to.

It is composed of straw, grass, leaves, wool, feathers, and moss, cemented together with gluten, which gives it a varnished appearance. The nest is said to be rather small in reference to the size of the bird, and is adapted in shape to the situation in which it was placed.

The eggs, two, three, four, or five in number, and of an elongated form, are white: they are laid towards the end of May, and are hatched after fourteen days' incubation. The young, when first able to fly, still follow their parents, by whom they are for some time supplied with food on the wing. 
1) 


\section{SWALITOW.}

CHIMNEY SWALLOW. COMMON SWALLOW. RED-FRONTED SWALLOW.

PLATE LXI.

$\begin{array}{ll}\text { Hirundo rustica, } & \text { Linneus. Pennant. } \\ \text { " domestica, } & \text { RaY. Brisson. }\end{array}$

IN the month of May, about a month after the arrival of the bird, the nest is commenced; and, as imported by one of its trivial names, the inside of a chimney is a common selection, and some angle or corner a few feet down is taken advantage of for the support that it affords. The precise situation is frequently resorted to that has been made use of in previous seasons.

The nest, which is open at the top, is formed of moist earth which the bird collects bit by bit in its bill, from the side of a pond or stream, or the middle of a road, as may often be seen. It is moulded into shape, intermixed with straw and grass, and is finally lined with feathers, or such like soft materials. A nest of this species has been found placed in a ventilating pipe, and was composed exclusively of feathers, no mud being used.

The eggs are usually from four to six in number, white, much speckled over with ash-colour, and dark red, or brown and rufous. 





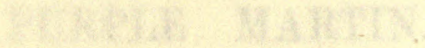

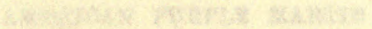

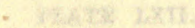

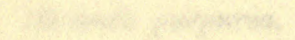

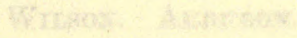

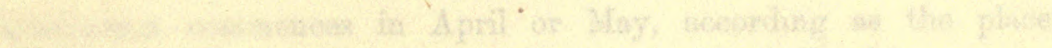

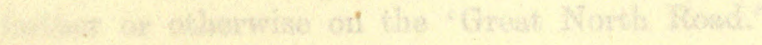

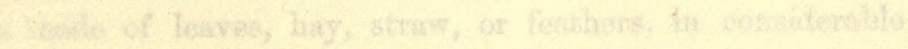

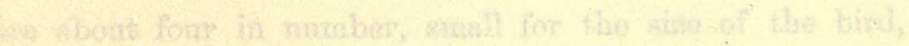

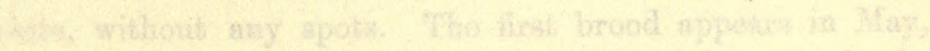

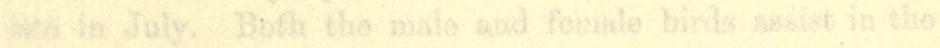

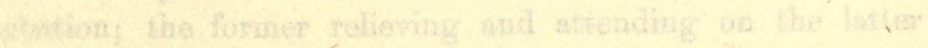

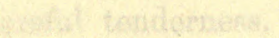

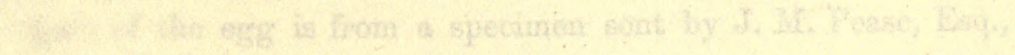

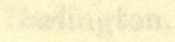





\section{PURPLE MARTIN.}

AMERICAN PURPLE MARTIN.

PLATE LXII.

Hirundo purpurea, WILson. Audubon.

Nidification commences in April or May, according as the place halted at is farther or otherwise on the 'Great North Road.'

The nest is made of leaves, hay, straw, or feathers, in considerable quantity.

The eggs are about four in number, small for the size of the bird, and pure white, without any spots. The first brood appears in May, the second late in July. Both the male and female birds assist in the work of incubation; the former relieving and attending on the latter with much careful tenderness.

The figure of the egg is from a specimen sent by J. M. Pease, Esq., North Lodge, Darlington. 


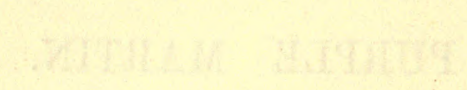






\section{MARTIN.}

HOUSE MARTIN. MARTIN SWALlOW. WINDOW SWALLOW.

PLATE LXIII.-FIG. I.

Hirundo urbica,

Pennant. Montagu.

THE nest of the Martin, which is generally built under the eaves of a house, but also frequently on the side of a cliff, is of an hemispheric form, and is lined inside with a little hay or feathers.

The eggs are four or five in number, smooth and white. Incubation lasts thirteen days.

The same nest is resorted to from year to year. Thus, the Rev. Gilbert White says:- 'July 6th., 1783, some young Martins came out of the nest over the garden door. This nest was built in 1777, and has been used ever since.' The young birds of one year often add another the following to 'The Row' of nests which ornament the eaves where their parents have built; and sometimes the birds will form a continuous line of the mud they build with along the wall, without any apparent or discernible motive, for there it remains without any use being made of it. The mud they use in building is tempered and cemented in some way or other, for it will adhere firmly to glass. 


\section{SAND MARTIN.}

BANK MARTIN.

PLATE LXIII.-FIG. II.

Hirundo riparia, Pennant. Montalu.

The nest of the Sand Martin, as intended by its name, is placed in the straight banks of rivers, cliffs of the sea-shore, sand-pits, and such other like situations as are sufficiently soft for the bird to perforatenot always at a high elevation: I have known them almost within reach of the hand from the beach. It hollows out for itself a way to its intended resting-place to the depth of from two to three, and even nearly four feet. These 'excavators' complete their work, though they are such 'feeble folk,' in about a fortnight. The same hole is resorted to from year to year, or, if it has fallen away, another is hollowed out in the same neighbourhood. The weight of sand mined in a day is from sixteen to twenty ounces, and pebbles of even more than two ounces in weight have been known to be removed.

The eggs are from four to six in number, and white. They are very tender, and are hatched after an incubation of twelve or thirteen days. 




\section{PIED WAGTAIL.}

WATER WAGTAIL. WHITE WAGTAIL. BLACK AND WHITE WAGTAIL. WINTER WAGTAIL. PEGGY WASH-DISH. DISH-WASHER.

PLATE LXIV.-FIG. I.

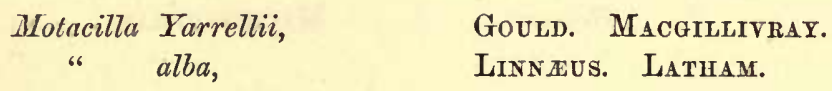

THE nest is commenced in the beginning or middle of April, according to the season. It is placed in situations of very opposite kinds-in a hole of a stone wall, the side of a bridge, in a hollow of a tree, on a heap of stones, the bank of a streamlet or river, the side of a stack of hay, peat, or wood, a stony or grassy bank, a mud wall, or on the grass. Meyer has known one in the middle of a turnip-field. It is about five inches wide externally, by about three and a half internally, and is composed of stems of grass, leaves, small roots, and moss, lined with wool, hair, thistle-down, or feathers, and any other such soft substances, all somewhat rudely, or rather loosely put together.

The eggs, five or six in number, and of an elongated oval form, are light grey, or greyish or bluish white, sometimes tinged with yellowish or greenish, spotted all over with grey and brown. They vary, however, very considerably both in size and colour. 


\title{
WHITE WAGTAIL.
}

\author{
GREY AND WHITE WAGTAIL.
}

PLATE LXIV.—FIG. II.

$\begin{array}{cll}\text { Motacilla alba, } & \text { Linneus. GMelin. } \\ \text { "Brissoni, } & \text { MacGillivray. }\end{array}$

THE nest is generally placed in a hole of a bank or of a tree, higher or lower indifferently; sometimes under the eaves of a thatched house, or between the timbers of a roof, among felled wood, or roots that the earth may have fallen away from, a meadow, under a bridge, or in a heap of stones. Both birds assist in its formation, bringing together for the purpose small sticks and twigs, moss, grass, straws, leaves, and roots, and lining the whole with wool and hair.

The eggs, which have little or no natural polish on them, and are four or five, six or seven in number, are bluish white in colour, speckled all over with minute grey specks, and spotted with larger spots of brown, principally at the larger end, occasionally in the way of an irregular belt.

The engraving is from a drawing of an egg in Mr. Birkbeck's collection. 



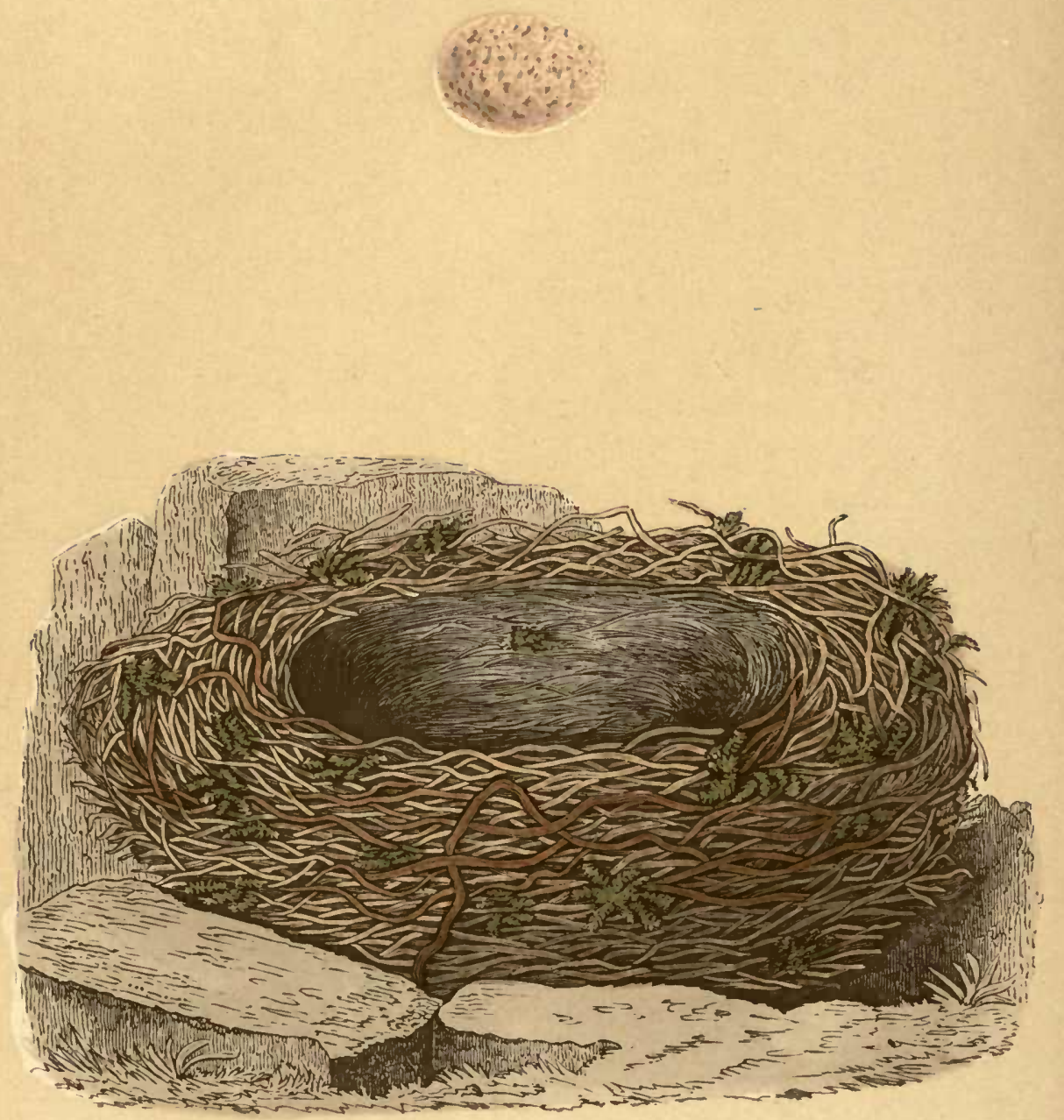





\section{GREY WAG'TAIL.}

WINTER WAGTAIL. YELLOW WAGTAIL.

PLATE LXV.

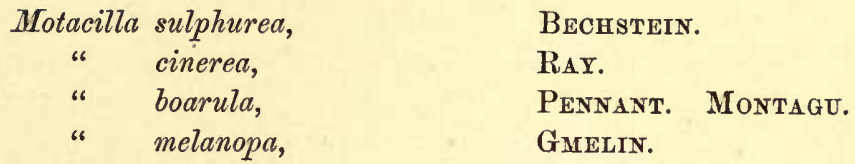

THE nest is generally placed on the ground, among grass or stones, in the hollow of a bank or rock, usually near the borders of a stream, but not always, for it has sometimes been met with at a distance from water. One pair has been known to build in a spout, and the following year on a shelf in an outhouse, to which a broken pane of glass gave them ingress; and again, on the window sill of a dairy, near the previous one. Another pair built their nest between the 'switches' of a railway, within two or three inches of every train that passed. It is formed of small fibres and roots, moss and grass, and is lined with wool, hair, or feathers.

The eggs are from five to six, or even eight in number, greyish or yellowish white, mottled with light brown and grey. They vary in depth of colouring, some being nearly cream white, and others nearly pale yellowish brown: they are of a short oval shape. 

-

- 




\title{
GREY-HEADED WAGTAIL.
}

BLUE-HEADED WAGTAIL. YELLOW WAGTAIL.

PLATE LXVI.-FIG. I.

\author{
Motacilla neglecta, Gould. Jenxns. \\ " Alava, Linneus. Temminck. \\ Budytes flava, Prince of Musignano.
}

THE nest is generally placed on the ground in holes or hollows, especially in marshy or moist places, and among the projecting roots of trees; also, it is said, in fields and meadows. It is formed of grass, moss, or heath, lined with finer portions of the former materials, and hair.

The eggs are about six in number, whitish in colour, mottled nearly all over with yellowish brown and grey.

The engraving is from a drawing of an egg in Mr. Birkbeck's collection. 


\title{
YELLOW WAGTAIL.
}

\author{
RAY'S WAGTAIL.
}

PLATE LXVI.—FIG. II.

\author{
Motacilla flava, \\ Pennant. Montagu. \\ Budytes Rayi, \\ Prince of Musignano: Mexer.
}

THe nest is placed on the ground, or near it on the stump of a tree, and is compacted of dry stalks and fibres, and lined with hair. Meyer describes one made of moss, with a few tufts of grass outside, and a few horse-hairs within.

The eggs, four or five, or six in number, are pale brown, or greenish white, sprinkled all over with a darker shade, in some very obscurely, of grey, or pale rufons, or yellowish brown; some specimens are nearly pale dull yellow, slightly marbled over; these are said to be smaller in size. They are of a rather long oval form. The young birds are able to fly about the end of May. 
6 


\title{
RICHARD'S PIPIT.
}

\author{
PLATE LXVII. \\ Anthus Ricardi, Fleming. Bewick. Selby.
}

THE eggs are described as being of a reddish white ground colour, speckled with darker red and light brown.

Professor Thieneman figures two, both much resembling each other, but the one of a slightly darker shade than the other.

In the one the ground colour seems to be pale bluish grey, mottled all over with pale dull yellowish white, and dull white.

In the other, which is marked in a similar manner, the yellowish colour more predominates. 




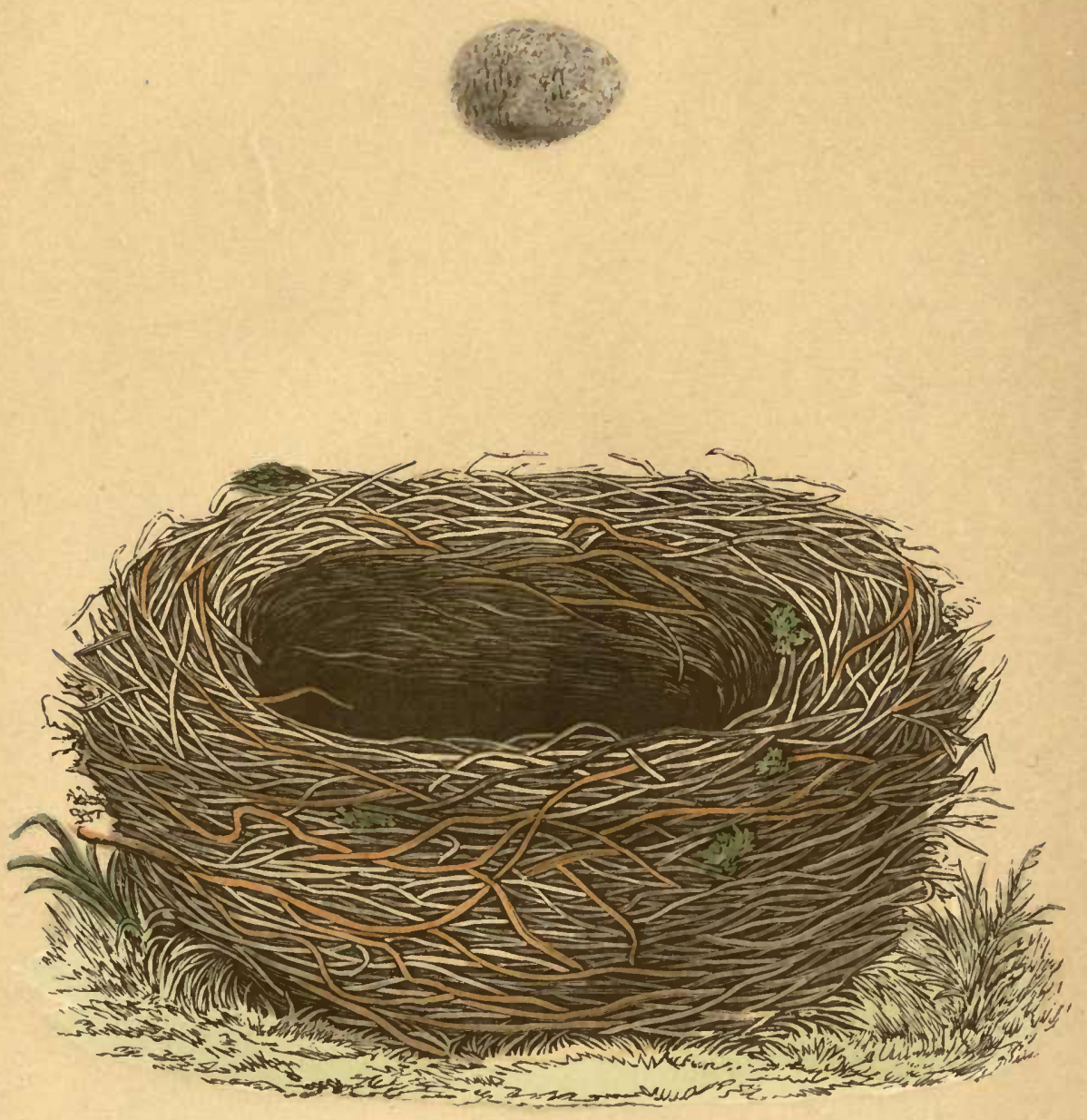




\section{MEADOW PIPIT.}

TITLARK. PIPIT. TITLING. MEADOW TITLING. MOSS CREEPER. LING BIRD.

GREY CREEPER. MEADOW LARK.

PLATE LXVIII.

$\begin{array}{cl}\text { Anthus pratensis, } & \text { Fleming. Latham. Selby. Godnd. } \\ \text { Alauda pratensis, } & \text { Pennant. Latham. } \\ \text { " trivialis, } & \text { Montagu. } \\ \text { " campestris, } & \text { Latham. }\end{array}$

The nest is placed either on or close to the ground, often in marshy places, among grass, near a tuft, on the branch of a very low bush, a bank, or a wall of turf. It is composed of grass, the finer portions constituting the lining, with occasionally a little moss and hair. One has been known to be built on the end of a plank, which formed part of a heap of timber.

The eggs are from four to six in number, of a light reddish brown, or reddish white, or pale brown, or pale blue colour, mottled over, especially near the larger end, with darker brown. They vary much in depth of colouring, some being much darker than others: hardly any two sets are exactly alike in this respect.

One fine variety, figured by Professor Thieneman, in his beautiful work, is wholly of a fine dark rich brown, slightly variegated by being here and there a trifle darker or lighter.

A second is of a rather pale bluish grey, mottled all over with darker spots of the same, and a zone of minute dots near the larger end.

A third is of a greenish yellow hue, mottled all over in a like manner.

The figures of the egg and the nest are taken from specimens obligingly forwarded for the use of this work, by J. R. De Capel Wise, Esq., of Lincoln College, Oxford. 
wits mocianas a 




\title{
RED-THROATED PIPIT.
}

\author{
PLATE LXIX.
}

\begin{tabular}{cc} 
Anthus & montanus, \\
“ & Ludovicianus, \\
“ & \multicolumn{1}{c}{ " } \\
“ & spinoletta, \\
“ & aquaticus, \\
Alaudla & Pensylvanica, \\
“ & spinoletta, \\
" & campestris spinoletta, \\
" & campestris, \\
" & Ludoviciana, \\
" & rufa, \\
" & rubra,
\end{tabular}

Косн.

Buonaparte. Lichtenstein. Audubon.

BuONaparte.

Bechatein. Temminck. Meyer. Richardson. Swainson. Brisson.

LinNiEUS.

GMelin.

LathaM.

Latham. Gmelin. WILsoN.

Latham. Garelin.

THE nest is built in mountainous regions, and the neighbourhood of water seems to be preferred, but not the sea-coast.

'The eggs are four or five in number, and of a dull grey colour, covered all over with pale brown spots, more or less confluent.

One fine variety is dull pale yellowish brown, with a distinct dark narrow band round the lower end.

A second is dark reddish grey, speckled all over with darker dots of the same, and a dark streak about the lower end.

A third is olive brown, with a few darker dashes.

A fourth is bluish and yellowish grey, marbled over with slightly darker patches. 

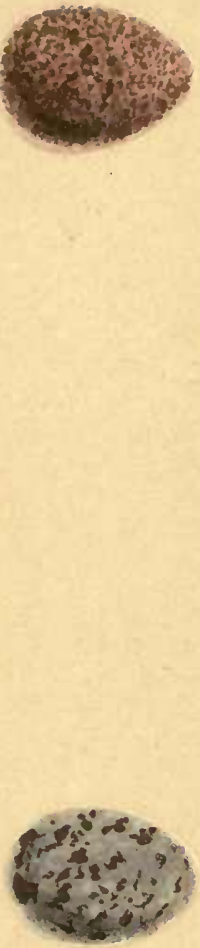


\section{TREE PIPIT.}

PIPIT LARK. FIELD TITLING. FIELD LARK. LESSER FIELD LARK.

TREE LARK. GRASSHOPPER LARK. LESSER CRESTED LARK. MEADOW LARK. SHORT-HEELED FIELD LARK.

PLATE LXX.

$\begin{array}{ll}\text { Anthus arboreus, } & \text { Secby. Jenrns. } \\ \text { " minor, } & \text { Bewick. } \\ \text { Alauda trivialis, } & \text { Pennant. Montagu. } \\ \text { " minor, } & \text { Iatham. }\end{array}$

'I'HE nest is placed on the ground, in woods and plantations, under the shelter or secrecy of a small shrub, or tuft of herbage, or perchance on the branch of some low bush, if close to the ground. It is formed of small roots and grass, with occasionally a little moss, and is lined with a few hairs. It measures about three inches across, and about an inch in thickness of construction.

The eggs are four or five in number, and are generally greyish white in colour, with a faint tinge of purple, clouded and spotted with purple brown, or purple red. They vary almost 'ad infinitum,' more so, it is said, than those of any other land bird. Some are dull bluish white, spotted with purple brown; others reddish white, entirely covered with specks of deep red; others reddish white, clouded with pale purple grey, and finely streaked and spotted with rust-coloured black; others again pale purple red, minutely marked in a net-like manner with a darker red.

One is pale grey, with large distinct spots and marks of dark greenish black, and a few yellowish specks. 
TREE PIPIT.

A second is reddish rust-colour, mottled all over with deeper spots of the same.

A third is of a dark olive brown ground colour, spotted and marked with a darker hue.

A fourth is pale grey, elegantly marked all over with greyish brown.

A fifth is of a rich red plum-colour, mottled all over with spots of a darker shade and a few of a paler red.

A sixth, a splendid variety, is of a remarkably rich dark fulvous brown, mottled all over with darker and lighter spots, and a fine belt round the thicker part of the egg. 


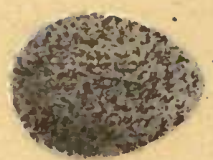




\section{ROCK - PTPTTY}

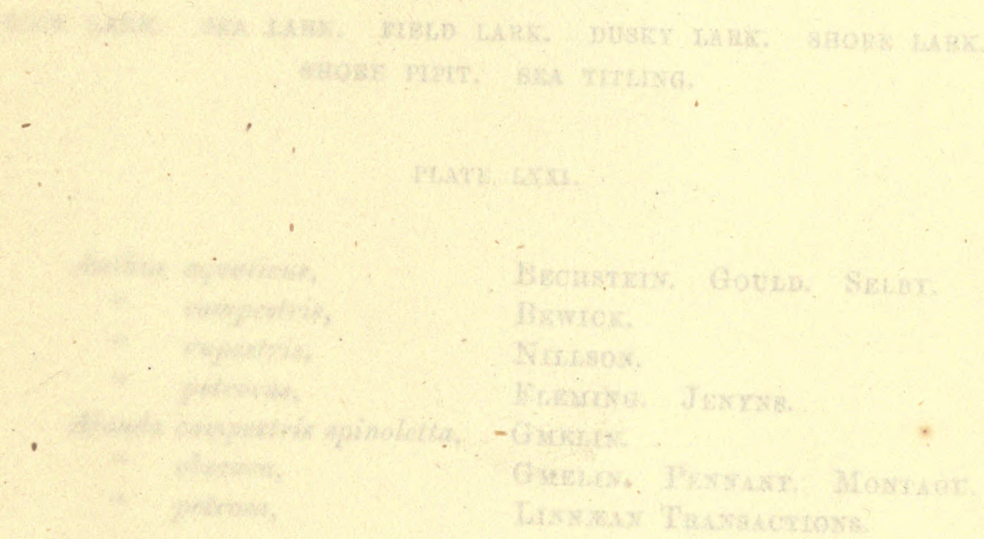

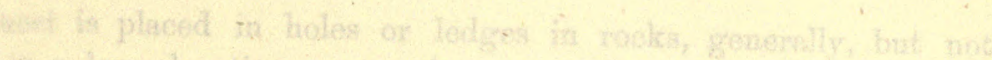

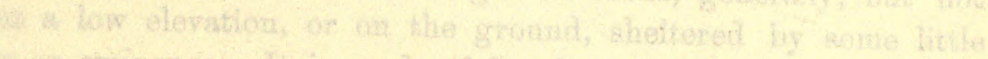

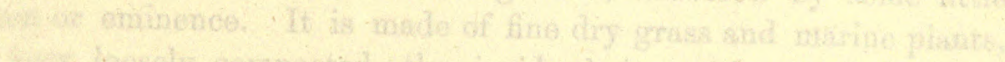

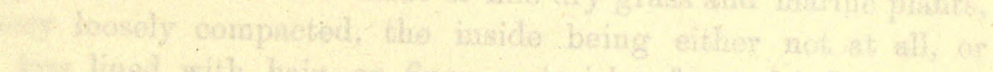

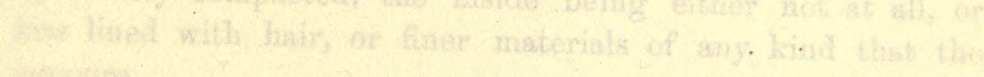
$\sin (x)$

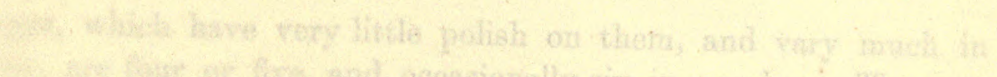

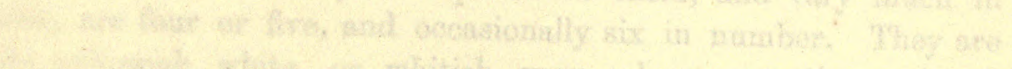

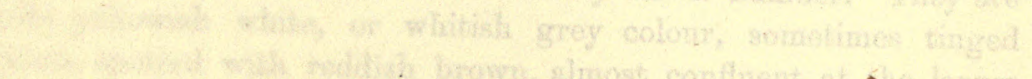

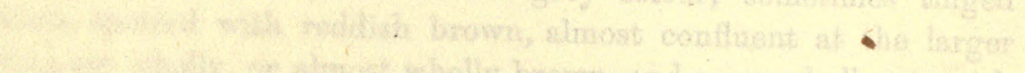

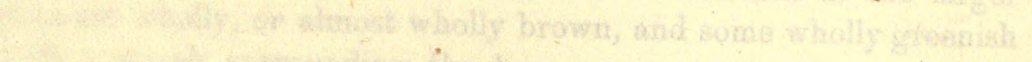

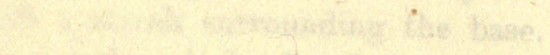

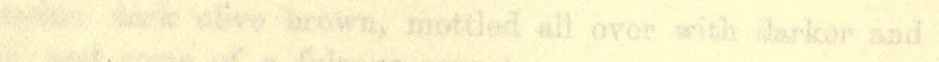

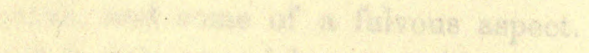

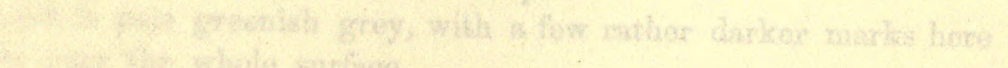

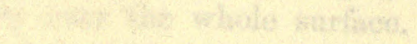

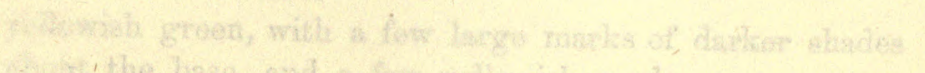

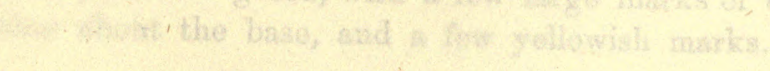





\section{ROCK PIPIT.}

ROCK LARK. SEA LARK. FIELD LARK. DUSKY LARK. SHORE LARK.

SHORE PIPIT. SEA TITLING.

PIATE LXXI.

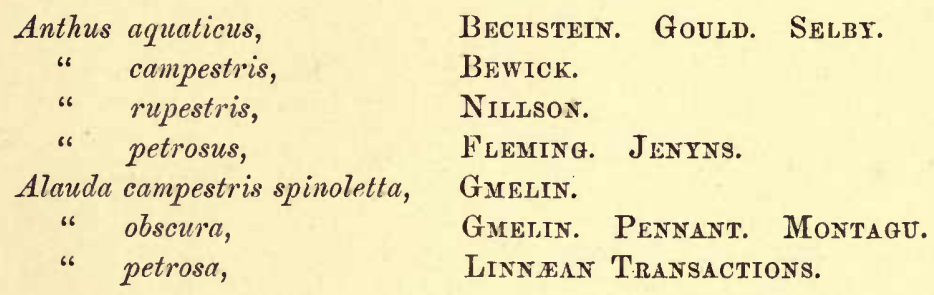

The nest is placed in holes or ledges in rocks, generally, but not always, at a low elevation, or on the ground, sheltered by some little projection or eminence. It is made of fine dry grass and marine plants, but is very loosely compacted, the inside being either not at all, or more or less lined with hair, or finer materials of any kind that the bird can procure.

The eggs, which have very little polish on them, and vary much in appearance, are four or five, and occasionally six in number. They are of a pale yellowish white, or whitish grey colour, sometimes tinged with green, spotted with reddish brown, almost confluent at the larger end; some are wholly, or almost wholly brown, and some wholly greenish grey, with a streak surrounding the base.

One is a rather dark olive brown, mottled all over with darker and lighter marks, and some of a fulvous aspect.

A second is pale greenish grey, with a few rather darker marks here and there over the whole surface.

A third is yellowish green, with a few large marks of darker shades run together about the base, and a few yellowish marks.

vOL. 1. 





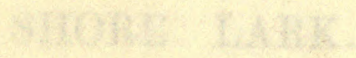

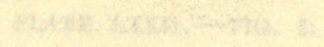

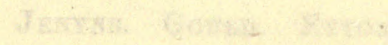

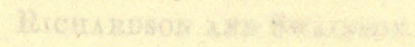





\section{SHORE LARK.}

PLATE LXXII.-FIG. I.

$\begin{array}{cl}\text { Alauda alpestris, } & \text { Jenrns. Gould. Erton. } \\ \text { “ cornuta, } & \text { Richandson and SwaInson. }\end{array}$

The nest, which is composed of fine grasses, circularly disposed, and lined with feathers, exactly resembles in colour the moss in which it is embedded, and is placed on the ground, in the desolate regions where moss is almost the only vegetation.

The eggs are four or five in number, greyish white, spotted with pale blue and brown spots. They are laid in the beginning of July.

The young, says Mr. Audubon, which are hatched about the middle of July, and fully fledged by the 1st. of August, leave the nest before they are able to fly, and follow their parents over the moss, in which. they drop, and endeavour to conceal themselves on the appearance of any danger. They run nimbly, and are fed for about a week. If observed and pursued, the same author further relates that they utter a soft 'peep,' open their wings to aid them in their escape, and separating, make off with great celerity.

The plate is from a drawing of an egg in the collection of H. F. Walter, Esq., of 67, Russell Square, London. 


\section{SHORT-TOED LARK.}

PLATE LXXII.-FIG. II.

Alauda brachydactyla,

Govis.

ThE nest is placed on the ground.

The eggs are four or five in number, and of a dull yellow colour. One is greyish brown, minutely dotted all over with yellowish brown. A second is grey, distinctly dotted all over with yellowish brown, a band of which encircles the base.

A third is pale yellowish green, slightly marked over with a rather darker shade.

A fourth is pale yellowish olive, slightly variegated all over with spots of a darker hue. 


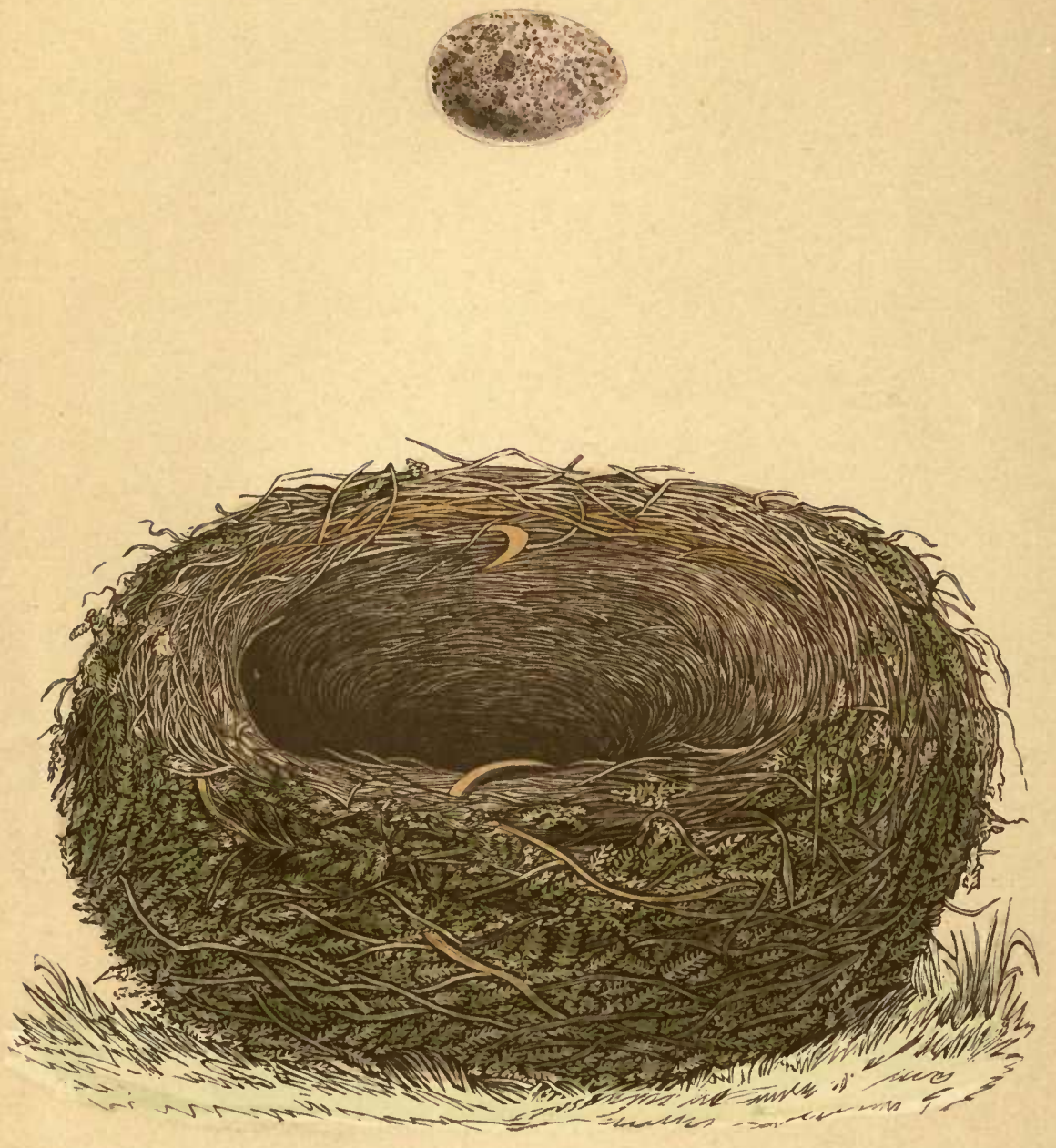




\title{
WOOD LARK.
}

\author{
PLATE LXXIII.
}

$\begin{array}{cl}\text { Alauda arborea, } & \text { Pennant. Montagu. Bewick. } \\ \text { " nemorosa, } & \text { Gmelin. } \\ \text { " cristatella, } & \text { Latham. }\end{array}$

The nest is placed upon the ground, beneath some low bush or tuft of grass, or at the foot of a tree; occasionally under the shelter of a fence or paling, or on a bank; one has been known on the trunk of a fallen oak, on the topmost bough of which, perhaps, in previous years when it still stood in all its pride, the bird had warbled forth her strains, and now when levelled with the earth, she 'could not bid the spot adieu,' but sang a daily requiem over the fallen remains. The outside materials are small roots, grass, and sometimes moss, and the lining smaller grasses, with occasionally a little hair.

The eggs, which are laid at the end of March or beginning of April, and also in July, there seeming to be two broods in the year, are four or five in number, of a pale reddish white, or yellowish brown ground colour, spotted and speckled with dull reddish brown, or dark grey, or brownish grey, with sometimes a few irregular dusky lines at the larger end.

'The figure of the nest is from a specimen obligingly forwarded by W. Bridger, Esq.; and that of the egg from one taken in Hampshire, early in the month of March, by the Rev. J. Williams. 




\title{
SKY LARK.
}

\author{
LAVROCK. FIELD LARK.
}

PLATE LXXIV.-FIG. I.

$\begin{array}{cl}\text { Alauda arvensis, } & \text { Pennant. Montago. } \\ \text { " vulgaris, } & \text { Willughby. Ray. }\end{array}$

THE nest is placed in a hollow scraped in the ground, with or without the fortuitous 'shelter of a clod of earth or tuft of herbage. It is placed in various situations, and is made of grasses, and a few chance leaves, the coarser outside, the finer on the inner part. The male bird appears to bring the materials to the spot, where the female is engaged in arranging them. The young are hatched in about a fortnight; they do not quit the nest until fairly fledged, but return to it to roost at night for some time after they have left it.

The eggs, three, four, or five in number, vary much both in form and colour; some are of a greyish white colour, with a tinge of purple or green, and freckled and mottled nearly all over with a darker shade of grey, greyish brown, or brown; others are of a deep sombre hue, and in some the chief part of the colour is concentrated at the larger end, either wholly or only partially around it. They are usually placed with their smaller ends towards the centre. 


\section{CRESTED LARK.}

PLATE LXXIV.-FIG. II.

Alauda cristata,

GoULD.

The nest, placed on the ground, is made of grasses.

The eggs are four or five in number, of a light grey colour, spotted with light and dark brown.

One is greenish yellow, marked over moderately with darker patches.

A second is yellowish brown, speckled with darker, with a band of reddish brown near the obtuse end.

A third is greyish brown, elegantly spotted and dashed over with yellowish brown and dark grey.

A fourth is greyish olive, speckled and spotted all over with darker marks.

A fifth is reddish brown, very richly marked all over with large dark marks, some brown, and others yellowish, run together at the base.

A sixth, a splendid variety, figured by Professor Thieneman, is grey, most elegantly dotted all over with clear red, a galaxy of which encircles the base.

A seventh is grey, mottled with yellowish brown.

An eighth darker grey, thickly speckled all over with greenish yellow.

A ninth is grey, obscurely marked all over with yellowish brown, mostly at the larger end.

The figure is from a drawing of a specimen in the collection of H. F. Walter, Esq., of 67, Russell Square. 

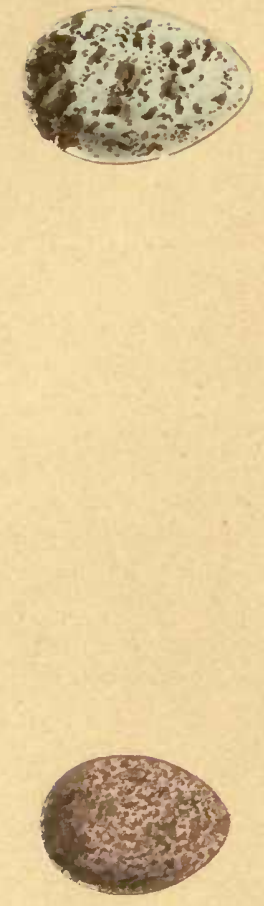


\section{SNOW BUNTING.}

SNOW FLAKE. SNOW FLECK. SNOW FOWL. TAWNY BUNTING. BRAMBLING. GREAT PIED MOUNTAIN FINCH.

LESSEP MOUNTAIN FINCH. GREATER BRAMBLING.

PLATE LXXV.-FIG. I.

Plectrophanes nivalis, Emberiza nivalis,

" glacialis,

" mustelina,

" montana,
Meyer. Selbi.

Linnaus. Gmelin. Latiam.

Latham. Pennant.

GMejin.

Gmelin. Latham. Pennant.

The nest, which is made of dry grass, lined with hair and a few feathers, is generally fixed in the crevice of a rock, or among stones on the ground. Captain Lyons, R.N., found one placed in the bosom of a dead Esquimaux child, a situation suggestive of affecting thoughts, but the history connected with which must remain unknown until that day when both land and sea shall give up their dead. Others have been found under the shelter of the drift timber, which is, alas! but too frequently to be met with on the shores of the frozen seas. How many a tale also does it tell with its expressive, though silent voice,

\section{' Of those}

For whom the place was kept, At board and hearth so long.'

Fervently do I trust that the 'brave old oak' of the gallant Sir John Franklin's trusty ships, may yet be found to have afforded no shelter for the nest of the Snow-flake, but that in the words of the still-used form of the old bills of lading, 'so may the good ship arrive at her desired port in safety.'

VOL. I. 




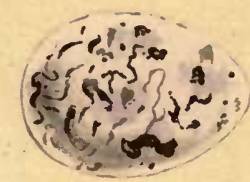




\section{BUNTING.}

COMMON BUNTING. CORN BUNTING. BUNTING LARK.

PLATE LXXVI.

Emberiza miliaria,

Pennant. Montagu. Bewick.

Nidification commences towards the end of April.

The nest, which is begun and finished in the course of this month, is usually placed on the ground, or only slightly raised above it by coarse herbage, and frequently on a bank, sometimes in a bush, or under a hedge, among the grass, is composed of dry straws and grasses, lined with smaller grasses and small fibrous roots, moss, and hair, rather neatly, but not finely, compacted. It is somewhat large and thick, but shallow inside.

The eggs, generally four, or rarely five or six, in number, and of an obtuse oval shape, are of a whitish colour, with a slight tinge of grey or red, sometimes pale purple red, streaked and spotted in a very irregular manner with dark purple brown and pale greyish purple. They differ a good deal in size, shape, and colour. In some the ground colour is nearly white.

One variety is of a dull grey, the larger end marked with pale reddish brown and some dark marks, a few of which are scattered over the surface.

Another is yellowish brown, with a few darker marks of the same.

A third, a mixture of dull pale yellow, brown, and red, with a few dark marks.

A fourth, light-coloured greyish brown, with a few very fine large dark blots, and some smaller marks at the larger end. 


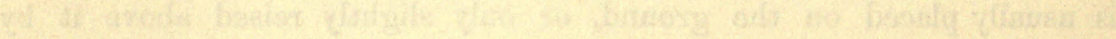

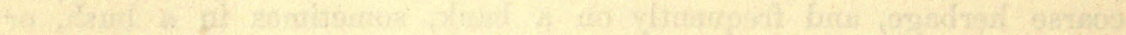

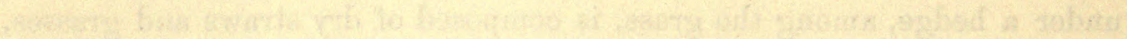

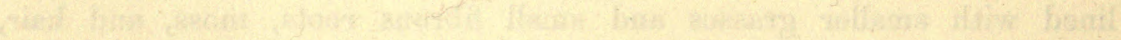

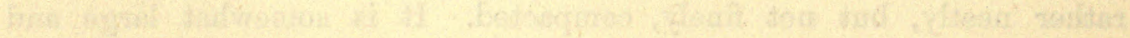

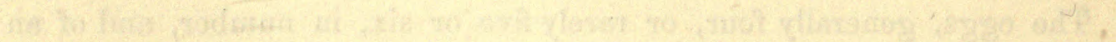

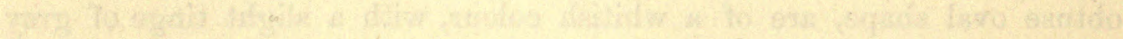

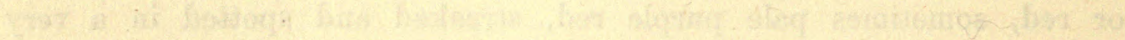

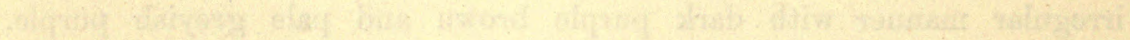

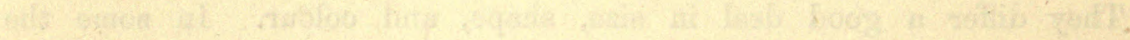

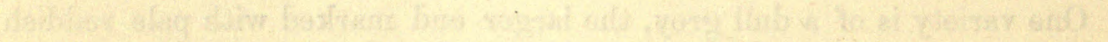

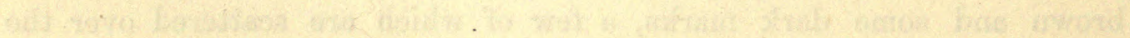

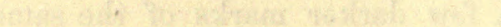

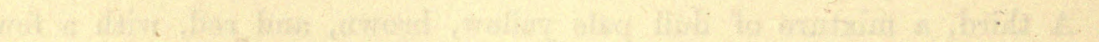

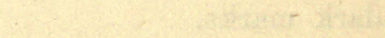

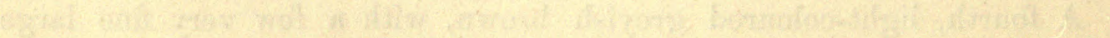

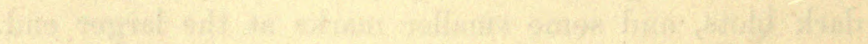


(43

依 


\section{BLACK-HEADED BUNTING.}

REED BUNTING. WATER SPARROW. CHINK. BLACK BONNHT.

PASSERINE BUNTING. MOUNTAIN SPARROW.

PLATE LXXVII.

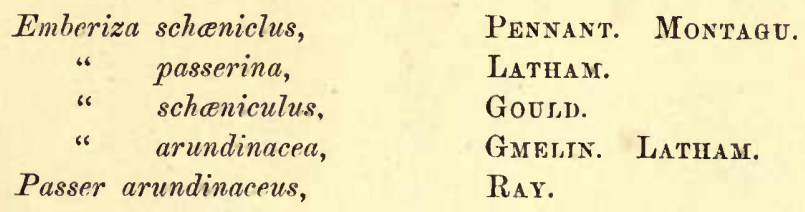

ThE nest is commonly placed on the ground, among coarse grass, weeds, sedge, or rushes, on a bank near the edge of the water which the bird frequents, and occasionally in the lower part of some low bush or stump, a few inches above the ground; sometimes it is said to have been met with in a furze or gorse bush, at a considerable distance from water; and Mr. Hewitson relates that he has, though rarely, found it at an elevation of two feet or more above the water, and supported on a mass of fallen reeds. J. Barstow, Esq., of Garrow Hill, near York, has informed me of one he found near there on the 7th. of July, 1852, in a hedge about a yard from the ground, some way from any pond: it contained four eggs. It is composed of grasses and fragments of rushes, lined with the down of the reed, a little moss, or finer grass, or hair.

The eggs are four or five in number, of a pale purple brown, greenish, or brownish, or purple white colour, streaked and strongly spotted in a pleasing manner with a darker shade of the same; sometimes the end is delicately marked with a texture of fine lines. They are laid about the first week in May, and occasionally a second brood is produced in July. They are somewhat oblong, and taper a little at each end. 


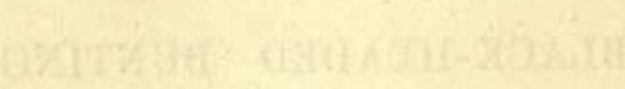




\section{(6)}

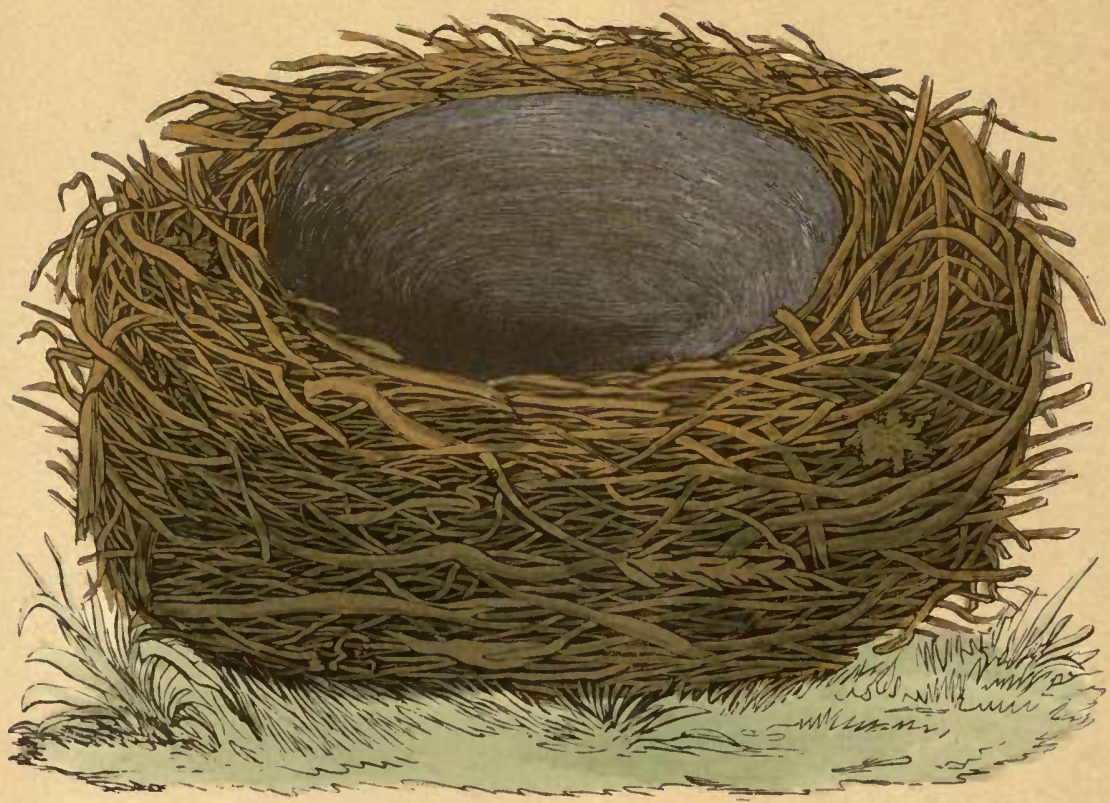




\section{YELLOW-HAMMER.}

YELLOW BUNTING. YELLOW YOWLEY. YELLOW YELDRING. YELLOW YOLDRING. YELLOW YITE. YELDROCK. YOLKRING. YOIT. SKITE. GOLDIE.

PLATE LXXVIII.

Emberiza citrinella, " Rava,
Pennant. Montagu.

Brisson.

THe nest, which is rather bulky, is usually placed either on or very near to the ground, on a bank, or sheltered by some bush, among the twigs, or in a clump of grass, or tuft of other herbage. It is formed of moss, small roots, small sticks, and hair, tolerably well compacted together; the finer parts of the materials being of course inside. The late William Thompson, Esq., of Belfast, knew one in the middle of a field; he also relates that in the garden of a friend of his near that town, a pair of these birds built their nest at the edge of a gravel walk, and brought out four young, three of which being destroyed, the nest was removed with the fourth one for greater safety to a bank a few feet distant, and the old birds still kept to it, and completed the education of their last nestling. Mr. Blackwall mentions in the first volume of the 'Zoological Journal,' his having known an instance in which, in the month of June, the female laid her eggs upon the bare ground, sat upon and hatched them; and Mr. Salmon, of Thetford, mentions in the second volume of the 'Naturalist,' old series, page 274, his having on one occasion, on the 29th. of May, 1834, found the nest at the height of seven feet from the ground, in a broom tree. Mr. Hewitson, too, found one at a height of six feet from the ground in a spruce fir, and Mr. M. C. Cooke has informed me of one found near Swanscombe, in a bush at a height of twelve feet. 
The eggs, from three to four or five, and occasionally six in number, are of a pale purple white colour, streaked and speckled with dark reddish brown; the streaks frequently ending in spots of the same colour. Some have been known of a red colour, with reddish brown streaks and lines, others quite white, others entirely of a stone-colour, and others again of a stone-colour, marbled in the usual way. In a nest in which was one egg of the ordinary size, there were two others of the Lilliputian dimensions of those of the Golden-crested Wren. The young are seldom able to fly before the second week in June, being about a fortnight after they have been hatched; they keep together at night for a short time before they finally separate. Two broods are occasionally reared in the year. 


\section{,}




\section{cesters}

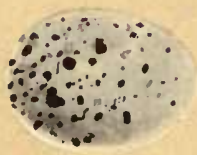




\section{CIRL BUNTING.}

FRENCH YELLOW-HAMMER. BLACK-THROATED YELLOW-HAMMER.

PLATE LXXIX.-FIG. I.

$\begin{array}{cl}\text { Emberiza cirlus, } & \text { Pennant. Montaqu. Bewick. } \\ \text { “ elcathorax, } & \text { Bechstein. }\end{array}$

THE nest is placed in furze or low bushes, and is usually made of dry stalks of grass and a little moss, lined with hair and small roots; some are wholly without moss or hair, and are composed entirely of the other materials, the small roots constituting the lining. R. A. Julian, Esq., Jun., has known one, containing four eggs, which he met with in July, 1850, in a steep bank: it may have been a second one of the year.

The eggs are four or five in number, of a dull bluish white, distinctly streaked and speckled with dark brown: they vary much in colour and markings. The young are hatched in about a fortnight. 


\title{
ORTOLAN.
}

\author{
ORTOLAN BUNTING.
}

PIAATE LXXIX.-FIG. II.

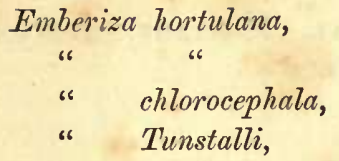

Linnzeus. Latham.

Selby. Jenyns. Gould. Móotagu. Bewick. LATHAM.

The Ortolan Bunting begins to build early in May.

The nest is placed in corn fields, and adapted to some hollow in the ground, or the latter possibly to it; Selby adds thickets and low hedges as places of its nidification also. It is formed of dry grass and small roots, thickly lined with finer portions of the latter; in some the inside is finished with a few hairs.

The eggs are four or five, sometimes, though rarely, six in number; they vary much in markings.

Professor Thieneman figures four, one of a pale dull bluish grey, with a few dark brown marks; a second with a tinge of red, and the marks principally agglomerated at the larger end; a third of a yellowish cast, with dark marks and streaks; chiefly at the thicker end; and a fourth of a dull bluish hue, marbled all over with different shades of brown.

END OF VOL. I. 
$a^{4}+x^{2}+x^{2}$

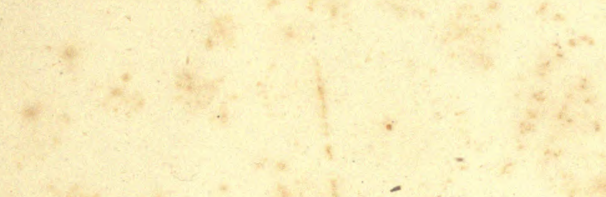

$\operatorname{los}^{2}+\frac{2}{2}$

$\cdot x^{2}+2=0$

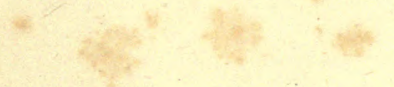

$x^{2}+3 x+4=2$
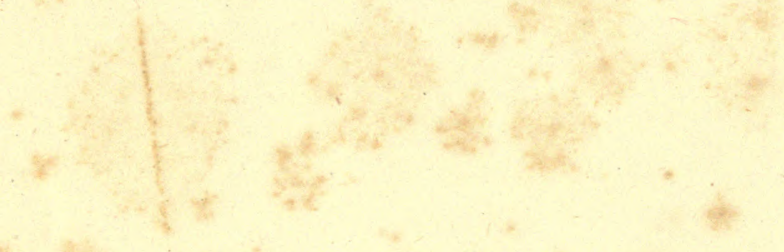

$y^{2}$

25

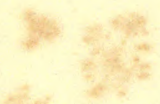

ate
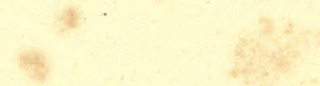

$2 x$

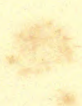

$+4$

3)

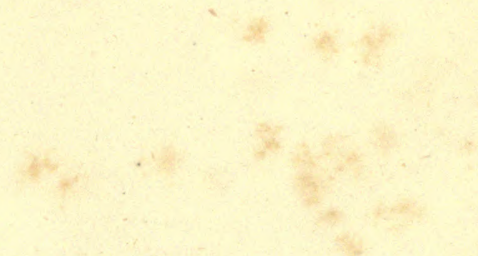

35

$\therefore$ an

$x^{2}$

$*$

$3=2$

$x^{2}+x^{2}-1$

$+$ 
RETURN TO the circulation desk of any

University of California Library

or to the

NORTHERN REGIONAL LIBRARY FACILITY

BIdg. 400, Richmond Field Station

University of California

Richmond, CA 94804-4698

ALL BOOKS MAY BE RECALLED AFTER 7 DAYS

2-month loans may be renewed by calling

(415) 642-6233

1-year loans may be recharged by bringing books to NRLF

Renewals and recharges may be made 4 days prior to due date

DUE AS STAMPED BELOW

\section{JAN $2 \uparrow 1990$}

DEC 151989

Santa Cruz Jitney 
$\therefore \quad \therefore$.

इ2 ?

\% (2). 
